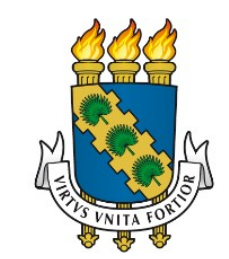

UNIVERSIDADE FEDERAL DO CEARÁ

FACULDADE DE ECONOMIA, ADMINISTRAÇÃO,

ATUÁRIA E CONTABILIDADE

PROGRAMA DE PÓS-GRADUAÇÃO EM ADMINISTRAÇÃO E CONTROLADORIA

FRANCIS DE SOUSA FERNANDES

COMPETÊNCIAS GERENCIAIS NO ÂMBITO DOS INSTITUTOS FEDERAIS DE EDUCAÇÃO

FORTALEZA 
FRANCIS DE SOUSA FERNANDES

\section{COMPETÊNCIAS GERENCIAIS NO ÂMBITO DOS INSTITUTOS FEDERAIS DE EDUCAÇÃO}

Dissertação apresentada ao Programa de PósGraduação em Administração e Controladoria da Faculdade de Economia, Administração, Atuária e Contabilidade da Universidade Federal do Ceará. Área de Concentração: Gestão Organizacional.

Linha de Pesquisa: Estudos organizacionais e gestão de pessoas.

Orientador: Prof. Dr. Augusto Cézar de Aquino Cabral

\section{FORTALEZA}


Dados Internacionais de Catalogação na Publicação

Universidade Federal do Ceará

Biblioteca Universitária

Gerada automaticamente pelo módulo Catalog, mediante os dados formecidos pelo(a) autor(a)

F399c Fensandes, Francis de Sousa.

Competências gerenciais no âmbito dos Institutos Federais de Educação / Francis de Sousa Fernandes. 2018.

$108 \mathrm{f}$ : il. color.

Dissertação (mestrado) - Universidade Federal do Ceará, Faculdade de Economia, Administração, Atuária e Contabilidade, Mestrado Profissional em Administração e Controladoria, Fortaleza, 2018.

Orientação: Prof Dr. Augusto Cézar de Aquino Cabral.

1. Competências gerenciais. 2. Gestão pública. 3. Instituto Federal. I. Título. 


\section{COMPETÊNCIAS GERENCIAIS NO ÂMBITO DOS INSTITUTOS FEDERAIS DE EDUCAÇÃO}

Dissertação apresentada ao Programa de PósGraduação em Administração e Controladoria da Faculdade de Economia, Administração, Atuária e Contabilidade da Universidade Federal do Ceará. Área de Concentração: Gestão Organizacional.

Linha de Pesquisa: Estudos organizacionais e gestão de pessoas.

Aprovada em: $21 / 03 / 2018$.

BANCA EXAMINADORA

Prof. Dr. Augusto Cézar de Aquino Cabral (Orientador)

Universidade Federal do Ceará - UFC

Prof. Dra. Sandra Maria dos Santos

Universidade Federal do Ceará - UFC

Prof. Dr. José Milton de Sousa Filho

Universidade de Fortaleza - UNIFOR 
À minha querida mãe! 


\section{AGRADECIMENTOS}

Agradecer é sinônimo de gratidão eterna.

Ao Instituto Federal do Piauí pela oportunidade.

Aos amigos e colegas de trabalho.

Aos professores do programa pela disseminação do conhecimento.

Aos colegas e amigos de turma.

Ao professor Augusto Cabral pela confiança no desenvolvimento deste estudo.

Agradeço ainda, de modo especial, a Francisca Maria de Jesus Fernandes, pela luta que travou durante toda sua existência terrena para colocar o pão de cada dia na mesa, sem a senhora eu não estaria aqui, nesse exato momento, escrevendo, pensando e sentindo o seu amor e dedicação. 
"Convém não esquecer, contudo, que a realização nobre exige três requisitos fundamentais, a saber: primeiro, desejar; segundo, saber desejar; e, terceiro, merecer, ou, por outros termos, vontade ativa, trabalho persistente e merecimento justo". Lísias, em "Nosso Lar”. André Luiz (1987, p.49) 


\section{RESUMO}

As competências, essencialmente, causam mudanças no desenvolvimento da organização, porém, é necessário que essas mesmas competências sejam identificadas e desenvolvidas com o intuito de diminuir cada vez mais as distâncias existentes entre as competências que se tem e as que se desejam, nesse sentido, as competências gerenciais são atividades, conhecimentos, habilidades ou atitudes e também características pessoais necessárias para melhorar o desempenho. Diretores gerais de campus dos Institutos Federais de Educação são sujeitos importantes no desenvolvimento dessas organizações e devem apresentar um perfil de competências gerenciais que gere resultados. Com o intuito de investigar a configuração do perfil de competências gerenciais nos Institutos Federais de Educação, Ciência e Tecnologia no território brasileiro, conforme a abordagem de valores concorrentes proposta por Quinn et al. (2015), este estudo usou de uma abordagem essencialmente quantitativa, e conforme o objetivo proposto, possui caráter descritivo. Por meio de uma pesquisa do tipo survey, foi aplicado um questionário autoadministrado a uma população de 602 sujeitos (diretores geral de campi), conseguindo um tamanho amostral de 241 respondentes. Foram realizadas estatística descritiva, análises exploratória e confirmatória do modelo teórico, na qual se conseguiu assegurar a validade e a confiabilidade das medidas e do construto, além de sua consistência interna tendo como apoio o software IBM SPSS Statistics Desktop. Concluiu-se a que há uma convergência preponderante no perfil dos gestores para o modelo de relações humanas no nível de frequência de uso relacionadas as competências que buscam criar e sustentar o compromisso e a coesão e no nível de domínio a tendência se volta para o modelo de sistema aberto, onde os gestores buscam efetivamente se adaptarem às mudanças e adquirirem suporte externo. Constatou-se ainda que em todas as dimensões os gestores usam as competências no dia a dia de suas atividades, porém, não demonstram capacidade conceitual e prática sobre as mesmas em igual proporção, existindo um hiato considerável de percepção de diferenças.

Palavras-chave: Competências Gerenciais. Gestão Pública. Instituto Federal. 


\begin{abstract}
The competences, essentially, cause changes in the development of the organization, however, it is necessary that these same competences are identified and developed with the intention of diminishing more and more the existing distances between the competences that have and those that are desired, managerial competencies are activities, knowledge, skills or attitudes and also personal characteristics necessary to improve performance. Campus Directors of the Federal Institutes of Education are important subjects in the development of these organizations and should present a profile of managerial competencies that generate results. In order to investigate the configuration of managerial skills profile in the Federal Institutes of Education, Science and Technology in the Brazilian territory, according to the concurrent values approach proposed by Quinn et al. (2015), this study used an essentially quantitative approach, and according to the proposed objective, it has a descriptive character. Through a survey-type survey, a self-administered questionnaire was applied to a population of 602 subjects (field directors), achieving a sample size of 241 respondents. Descriptive statistics, exploratory and confirmatory analyzes of the theoretical model were carried out, in which the validity and reliability of the measures and the construct were verified, as well as its internal consistency, with the support of IBM SPSS Statistics Desktop software. It was concluded that there is a preponderant convergence in the profile of managers for the human relations model at the level of frequency of use related to the competencies that seek to create and sustain commitment and cohesion and at the domain level the trend turns to the model open system, where managers effectively seek to adapt to changes and acquire external support. It was also observed that in all dimensions managers use the skills in the day to day of their activities, but they do not demonstrate conceptual and practical capacity over them in equal proportion, and there is a considerable gap in perception of differences.
\end{abstract}

Keywords: Management Skills. Public administration. Federal Institute. 


\section{LISTA DE FIGURAS}

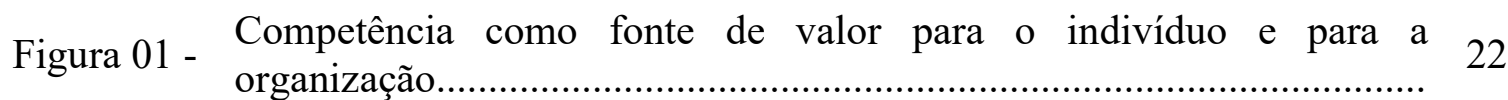

Figura 02 - Os cinco componentes da competência................................................ 24

Figura 03 - Estrutura de valores concorrentes: critérios de efetividade ..................... 40

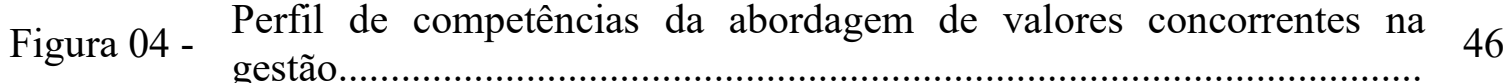

Figura 05 - Estrutura organizacional genérica dos institutos federais...................... 59

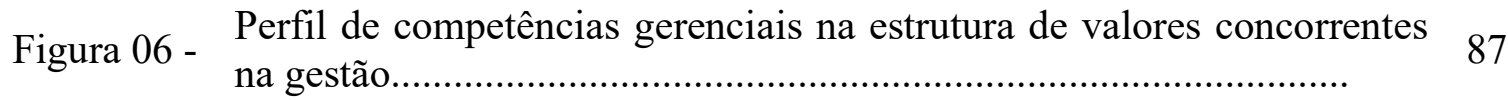




\section{LISTA DE QUADROS}

Quadro 01 - Competências associadas ao modelo de relações humanas......................... 42

Quadro 02- Competências associadas ao modelo de processos internos......................... 43

Quadro 03- Competências associadas ao modelo de metas racionais............................ 44

Quadro 04- Competências associadas ao modelo de sistemas abertos........................... 45

Quadro 05- Lócus e sujeitos estudados com base no modelo de Quinn e seus 47 colaboradores

Quadro 06- Pontuação da escala da matriz de avaliação de competências nos quesitos 63 domínio e frequência de uso.

Quadro 07- Competências específicas do instrumento de coleta associadas aos 63 modelos. 


\section{LISTA DE TABELAS}

Tabela 01- Quantidade de If's e campi por unidade da federação.................................. 56

Tabela 02- Tamanho da amostra para a população da pesquisa.................................... 58

Tabela 03- Representação dos respondentes por instituto federal............................... 70

Tabela 04- Cargo que ocupa como servidor público................................................ 71

Tabela 05- Tempo que atua como servidor público............................................... 72

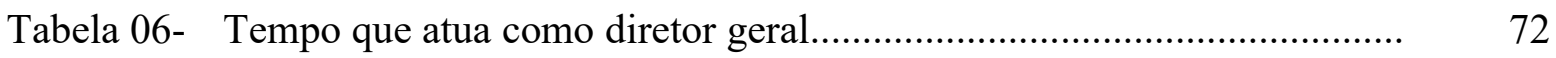

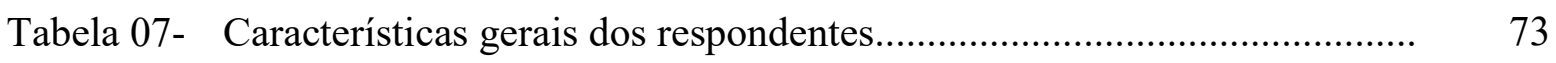

Tabela 08- Média e desvio padrão das competências da dimensão relações humanas.. 76

Tabela 09- Média e desvio padrão das competências da dimensão processo interno.... 77

Tabela 10- Média e desvio padrão das competências da dimensão meta racional......... 78

Tabela 11- Média e desvio padrão das competências da dimensão sistema aberto........ 79

Tabela 12- Média e desvio padrão das dimensões do modelo........................................ 80

Tabela 13- Teste de KMO e Bartlett........................................................................ 84

Tabela 14- Matriz de componentes rotativa e comunalidades.................................. 85

Tabela 15- Teste de alfa de Cronbach................................................................. 87

Tabela 16- Medidas de ajuste geral do modelo........................................................... 87 


\section{LISTA DE ABREVIATURAS E SIGLAS}

IF's - Institutos Federais de Educação

OCDE- Organização para Cooperação e Desenvolvimento Econômico

AVCG- Abordagem de Valores Concorrentes na Gestão 


\section{SUMÁRIO}

1 INTRODUÇÃO

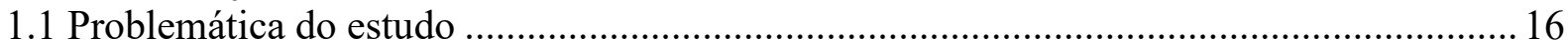

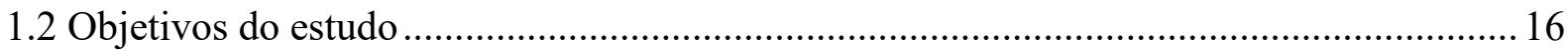

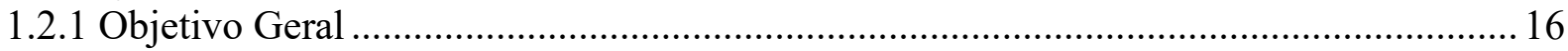

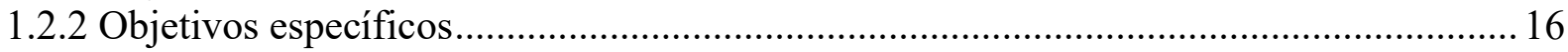

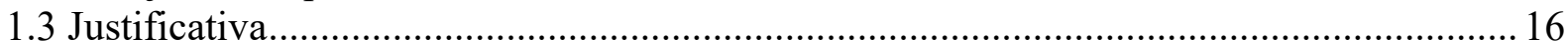

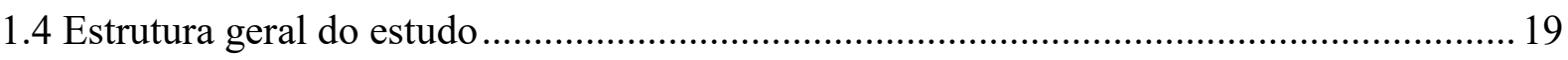

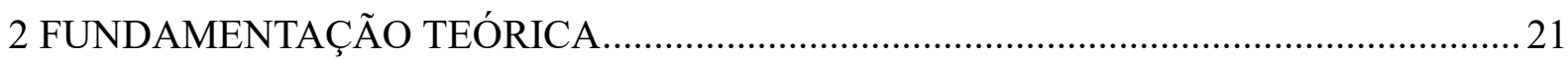

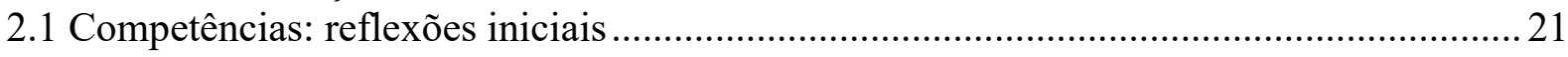

2.2 Competência e a especificidade do setor público...........................................................2.

2.2.1 O contexto da gestão pública brasileira........................................................................27

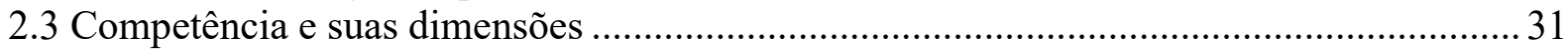

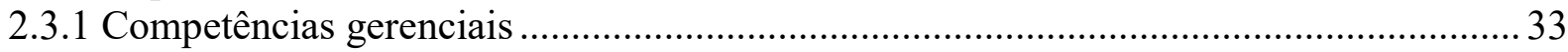

2.4 A abordagem de valores concorrentes na gestão ............................................................... 38

2.4.1 Cenários e sujeitos de estudos empíricos que utilizaram o modelo .................................. 46

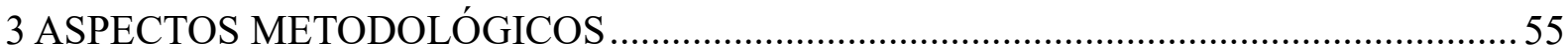

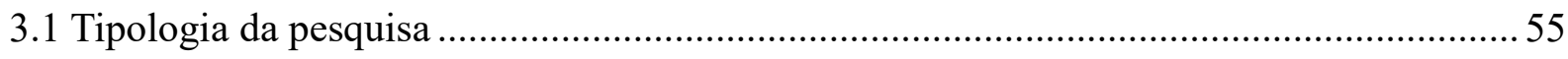

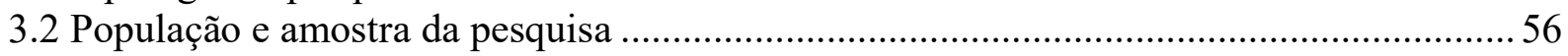

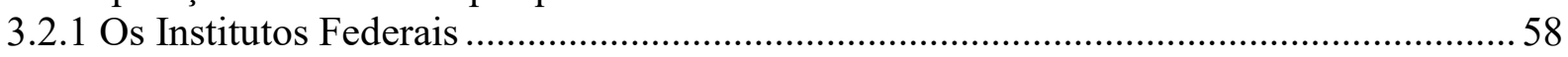

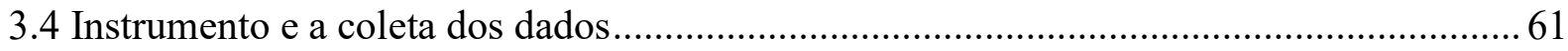

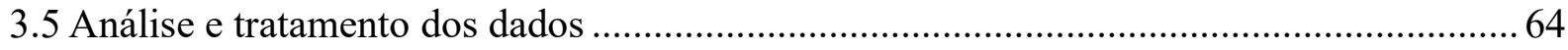

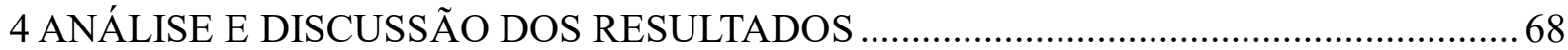

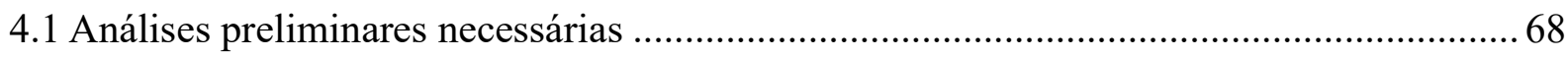

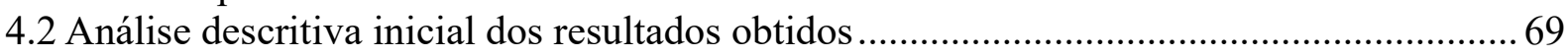

4.3 Análise descritiva da dimensão relações humanas .......................................................... 75

4.4 Análise descritiva da dimensão processo interno ……………………………………..... 77

4.5 Análise descritiva da dimensão meta racional.............................................................. 78

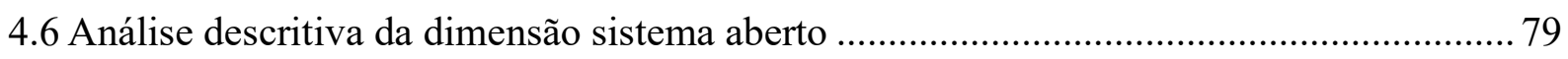

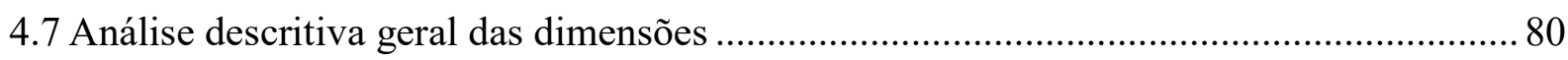

4.8 Analise Fatorial Exploratória e Confirmatória do modelo teórico ………………………....83

5 CONCLUSÃO

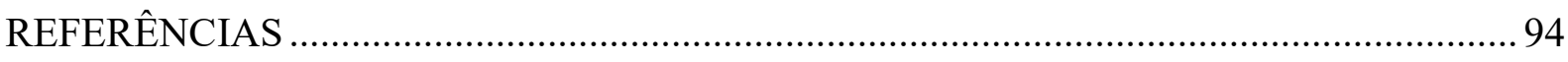

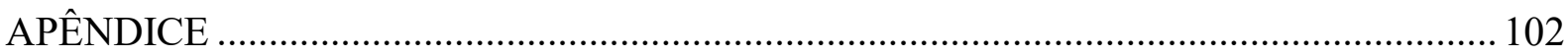




\section{INTRODUÇÃO}

Possuir e, especialmente, deixar evidente que se tem competências sempre foi uma exigência do viver em sociedade e as organizações também são a todo momento exigidas a mostrarem as suas competências (RESENDE, 2000). O mundo está em mudança, pedindo flexibilidade e autonomia, e as práticas de gestão de pessoas baseadas no trabalho não estão dando uma resposta adequada (NUNES; MARTINS, DUARTE, 2007). A noção de gestão de competências nas organizações, conforme sustentam alguns autores em literatura especializada, está sendo deslocada de organizações baseadas em trabalho para organizações baseadas em competências como uma mudança paradigmática (BRANS; HONDEGHEM, 2005). De acordo com a perspectiva de Lawler (1994), a diferença é na verdade uma questão de ênfase nas características das pessoas e no desempenho organizacional, em vez de empregos fixos.

Competências são componentes de um trabalho, que se refletem no comportamento e que são observáveis em um local de trabalho. Os elementos mais comumente observados são o conhecimento, as habilidades, atitudes, aptidões, adequação pessoal, comportamento de adequação pessoal e o impacto no desempenho do trabalho (NEAGU et al., 2015). A análise dos postos de trabalho, funções e habilidades e modelagem de competência são algumas das principais técnicas de gestão de pessoas. Elas fornecem as informações necessárias para produzir descrições de trabalho, perfis de função e especificações de pessoa e de aprendizagem, e são de fundamental importância na organização e design do trabalho, recrutamento e seleção, gestão de desempenho, aprendizagem e desenvolvimento, desenvolvimento de gestão, gestão de carreira, avaliação do trabalho e a concepção de qualidade e estrutura de pagamentos (ARMSTRONG; TAYLOR, 2014). O serviço público foi grandemente afetado por um contexto em rápida mudança dentro do qual ele é organizado e executado. As mudanças afetaram os ambientes técnicos, internos, externos e gerenciais que abrangem a organização e a prestação de serviços públicos. Esse novo contexto e caráter dos valores de mudança do serviço público, a erosão do capital humano, o empreendedorismo agressivo, a explosão da tecnologia da informação, o desenvolvimento da gestão do desempenho, a emergência de carreiras multissetoriais e a propagação de reformas contratuais, requer competências técnicas, éticas e de liderança aprimoradas (BOWMAN;WEST; BECK, 2010). 
A gestão pública brasileira, nos últimos anos, adotou uma postura característica das organizações privadas, trazendo pra si conceitos, discursos e práticas gerenciais, dentre elas a gestão por competências (OLIVEIRA; SANT'ANNA; VAZ, 2010). Pretende-se que a gestão pública entenda que o desenvolvimento de competências individuais das pessoas é condição necessária para a melhoria da qualidade da prestação de serviços e oferta de produtos (COTRIM FILHO; FARIAS, 2013).

Na busca pela promoção de mudanças na gestão pública brasileira, pela modernização nos processos de gestão, entende-se que a gestão por competências é um modelo gerencial adequado aos propósitos da administração pública brasileira, em especial a gestão dos Institutos Federais de Educação, Ciência e Tecnologia - IF's. Para tanto, torna-se necessário e indispensável que os tomadores de decisão que estão a frente dessas organizações sejam elas públicas ou privadas possuam determinadas competências. Para Ésther (2011) a forma de pensar do setor privado tem invadido o setor público e seu modo de gerir, resultando em mudanças significativas na forma como os gestores atuam. As discussões sobre competências gerenciais no âmbito da gestão empresarial há muito é evidenciada, quando se discute ou se tenta aplicar o contexto de competências nas instituições públicas não se consegue vislumbrar, inicialmente, quais são os objetivos a alcançar, por eles serem complexos e ambíguos, assim os gestores tomam decisões com lógicas de pensamento individuais (ÉSTHER, 2011).

Ao longo do tempo, a temática competência tem sido um tema central na literatura organizacional e o desenvolvimento gerencial está intimamente relacionado ao próprio desempenho organizacional (LIMA; ARAGÃO; GUIMARÃES, 2016). Para Melo, Silva e Parreira (2014) a liderança no contexto gerencial, através das competências, foi definida e operacionalizada de várias maneiras por alguns renomados pesquisadores, dentre eles, destacam-se Robert E. Quinn, Sue R. Faerman, Michael P. Thompson, Michael R. McGrath e David S. Bright, que desenharam a abordagem de valores concorrentes na gestão ao longo dos anos, com base em pesquisas realizadas para compreender a eficácia organizacional. Durante a década de 1990, os papéis de liderança foram amplamente reconhecidos, assim, uma variedade de papéis podem ser encontrados na literatura e essa diversidade reflete diferentes modelos de liderança sob os quais o modelo de valores concorrentes recai (MELO; SILVA; PARREIRA, 2014).

O estudo de Quinn (1988) tornou-se um modelo definido como diferenciado e privilegiado, dado que se baseia em teorias de liderança que incluem o desempenho de quatro imperativos de ação conflitantes e ao mesmo tempo necessários para a ação gerencial efetiva. 
Para Quinn et al. (2015) as competências gerenciais descritas no modelo refletem tanto a prática quanto a teoria organizacional, onde os quatro imperativos de ação (Colaborar, Controlar, Competir e Criar) e os modelos teóricos subjacentes (Relações humanas, Processo interno, Meta racional e Sistema aberto) ajudam a organizar os pensamentos sobre o que esperar de uma pessoa que ocupa uma posição de liderança. Os autores afirmam que o propósito centtral é ser capaz de integrar um conjunto diversificado de competências que permitirão agir com efetividade em um mundo de valores concorrentes em constante transformação (QUINN et al., 2015).

Nesse sentido, conforme Ruas (2005), as competências gerenciais são atividades, conhecimentos, habilidades e atitudes, assim como características pessoais necessárias para melhorar o desempenho da gerência. Além disso, a literatura também identifica outros componentes das competências gerenciais que também contribuem significativamente para o sucesso na carreira, tais como: liderança, gestão de crises, resolução de problemas, foco no cliente (HORNG et al., 2011).

A estrutura de valores concorrentes na gestão foi sendo construída desde as primeiras pesquisas de Robert E. Quinn, em 1988, desde então vem sofrendo aprimoramentos e acompanhando as mudanças ocorridas no mundo. Construído em base conceitual sólida em que explora a relação paradoxal e conflitante de quatro metamodelos de gestão: meta racional que busca a produtividade e lucratividade, resumida pelo imperativo competir; o modelo de relações humanas que foca na coesão e no compromisso, enfatizando o ideal colaborativo; o modelo de processo interno que destaca a necessidade de estabelecer e manter a estabilidade, representado pelo o imperativo controlar; e o modelo de sistema aberto, que enfatiza a na criação, através da ênfase dada a importância da capacidade de adaptação e inovação. A sua ênfase é justamente na aceitação de que gerentes e líderes devem ser constantemente confrontados com um leque de opções que parecem representar opções mutuamente excludentes, assim, para que suas tomadas de decisões sejam as mais eficazes possíveis é indispensável que aqueles integrem as diferenças e transcedam o paradoxo. Portanto para os autores a abordagem ajuda os futuros e atuais gestores a agirem com suas capacidades de rapidez, confiança, criatividade e ética, em um contexto organizacional permeiados de paradoxos (QUINN et. al, 2015).

Este modelo ajuda os teóricos organizacionais a melhor estruturar e compreender os principais dilemas enfrentados pelas organizações em busca da eficácia maximizada, é considerado um dos 40 modelos mais importantes na história da gestão e o fato de que as quatro dimensões do modelo descrevem tão de perto quatro grandes áreas de debate e 
pesquisa indica que os autores têm sido bem sucedidos em seus esforços para fornecer uma estrutura para a eficácia organizacional (HAVE et al., 2003).

\subsection{Problemática do estudo}

Diante do exposto, remete-se à questão central desta pesquisa: como se encontra configurado o perfil de competências gerenciais de gestores de instituições federais de educação brasileiras à luz do modelo da abordagem de valores concorrentes na gestão de Quinn et al. (2015)?

\subsection{Objetivos do estudo}

\subsubsection{Objetivo Geral}

Investigar a configuração do perfil de competências gerenciais nos Institutos Federais de Educação, Ciência e Tecnologia, conforme a abordagem de valores concorrentes proposta por Quinn et al. (2015).

\subsubsection{Objetivos específicos}

Analisar o perfil de competências gerenciais associadas ao modelo de meta racional (competição);

Analisar o perfil de competências gerenciais associadas ao modelo de processo interno (controle);

Analisar o perfil de competências gerenciais associadas ao modelo de relações humanas (colaboração); e

Analisar o perfil de competências gerenciais associadas ao modelo de sistema aberto (criação).

\subsection{Justificativa}

As competências, essencialmente, causam mudanças no desenvolvimento da organização, porém, é necessário que essas mesmas competências sejam identificadas e desenvolvidas com o intuito de diminuir cada vez mais as distâncias existentes entre as competências que se tem e as que se desejam (FERREIRA, 2015). No cenário atual as instituições de ensino superior, incluindo os Institutos Federais, estão sendo cobradas no que 
se refere a uma maior eficiência e qualidade na oferta de ensino, no desenvolvimento de pesquisas que dêem respostas sólidas aos desafios e problemas econômicos, sociais, políticos e culturais que o cidadão do país, dos estados e dos municípios passam diariamente (MARRA; MELO, 2005).

As instituições federais de ensino, em especial os Institutos Federais de Educação, Ciência e Tecnologia vêm experimentando e sofrendo mudanças. Marra e Melo (2005) afirmam que as organizações de ensino vinculadas ao governo federal têm sido alvo de críticas e questionamentos (reais objetivos, rigidez de sua estrutura organizacional, ineficiência, pertinência social dos serviços prestados) por parte da sociedade e do próprio governo. Para essas autoras, as práticas gerencias nessas organizações de ensino estão sendo realizadas sem planejamento, para resolver situações imediatas e de forma improvisada, com peculiaridade que aumentam o conflito e as contradições no exercício da função gerencial (MARRA; MELO, 2005). Diante de tal situação, os gestores têm um papel decisivo, pois os mesmos são cruciais no intuito de desenvolver potenciais dos servidores e são responsáveis, também, pelo melhoramento de processos, objetivando, com isso, alcançar um desempenho satisfatório, exigido pela sociedade (COTRIM FILHO; FARIAS, 2013).

Para Antonacopoulou e FitzGerald (1996) uma abordagem estruturada de um conjunto de competências iria ajudar as organizações a desenvolverem sistemas mais claros e focados para a concepção e implementação da formação e para a gestão de pessoas em ambientes onde funções desempenhadas são conduzidas inadequadamente. Nesse sentido, Moura e Bitencourt (2006) sinalizam em seu estudo, que colocar em prática estratégias organizacionais pode gerar necessidades de desenvolvimento de novas competências gerenciais, tendo em vista as atribuições e responsabilidades que passam a ser assumidas pelos gestores. Para esses autores buscar um articulação da história, da dinâmica dos processos e das práticas formais e informais da organização, combinar teoria e prática é uma alternativa para promover a integração entre estratégia e desenvolvimento de competências gerenciais (MOURA; BITENCOURT, 2006).

Ainda há uma lacuna nos estudos sobre o gestor e suas competências nos Institutos Federais de Educação, razão pela qual a perspectiva adotada neste trabalho visa preencher. Realizou-se pesquisa em periódicos brasileiros qualificados pela CAPES como “A2", "B1" e "B2" até 2016, usando critérios de busca pelo termo "competência" e "competências gerenciais" no resumo, título ou palavra-chave dos estudos, foram encontrados 353 (trezentos e cinqüenta e três) artigos, dos quais 39 (Trinta e nove), especificamente tratavam sobre competência gerenciais. Fazendo uma análise mais aprofundada e levando em 
consideração o objeto de estudo, dos 39 estudos encontrados que tratam sobre competências gerenciais especialmente, somente 08 (oito) têm como foco de estudo o contexto educacional, nitidamente universidades federais.

Periódicos pesquisados: BAR - Brazilian Administration Review; Cadernos EBAPE.BR-FGV; Organizações \& Sociedade; RAC - Revista de Administração Contemporânea; RAE Eletrônica; RAUSP-e; Revista Brasileira de Gestão de Negócios; Revista de Administração Pública; BBR - Brazilian Business Review; Gestão \& Produção; RAM - Revista de Administração Mackenzie; REAd - Revista Eletrônica de Administração; Administração Pública e Gestão Social; BASE - Revista de Administração e Contabilidade da Unisinos; Faces: Revista de Administração Gestão e Regionalidade; RAI : Revista de Administração e Inovação; Revista Brasileira de Gestão e Desenvolvimento Regional G\&DR; Revista de Administração da UFSM; Revista de Administração da Unimep; Revista de Ciências da Administração; Revista Gestão Universitária na América Latina - GUAL; Teoria e Prática em Administração; Revista Pensamento contemporâneo em Administração; Gestão e Planejamento; Contextus - Revista Contemporânea de Economia e Gestão; RAEP Administração: ensino e pesquisa; Análise - Revista de Administração da PUC-RS; Revista de Gestão e Secretariado; Organizações em contexto.

Estudos encontrados especificamente sobre competências gerenciais: Ésther, (2011); Pereira; Silva, (2011); Fleck; Pereira, (2011); Godoy; D’amelio, (2012); Sousa; Valadão Júnior, (2013); Bitencourt, (2004); Moura; Bitencourt, (2006); Brandão; BorgesAndrade; Guimarães, (2012); Félix, (2005); Oliveira; Sant'anna; Vaz, (2010); Moraes; Borges-Andrade; Queiroga, (2011); Lopes et al., (2010); Bitencourt, (2002); Glória Junior; Zouain; Almeida, (2014); Kenski; Brunstein, (2010); Morassutti; Grisci, (2002); Bündchen; Rossetto; Silva, (2011); Pelissari; Gonzalez; Vanalle, (2011); Ferigotti; Fernandes, (2014); Baisch, et al., (2012); Brito; Leone, (2012); Pimenta; Brasil, (2006); Carvalho; Stefano; Munck, (2015); Santos; Viagi, (2005); Oliveira; Lima, (2013); Pereira, et al. (2015).

O presente estudo é relevante, no que se refere às questões teóricas, pois buscará uma base fundamental para apresentar e evidenciar as competências gerenciais ajustadas ao contexto dos campi dos IF's, consequentemente aplicável ao serviço público em contextos semelhantes. No sentido prático, da realidade dos processos organizacionais, entende-se que possa chegar a um conjunto de competências gerenciais condizentes para a consecução de uma maior efetividade nas ações de direção de campus dos IF's, consequentemente esses critérios podem ser utilizados para o processo de designação dos diretores de campi da 
instituição, além da possibilidade de contribuir com uma iniciativa (ou uma ferramenta) de implementação da gestão por competências nos IF's.

Portanto, o levantamento das competências necessárias e de como elas estão configuradas atualmente para o gestor de campus dos Institutos Federais de Educação podem auxiliar nas decisões sobre o desenvolvimento de competências gerencias compatíveis e ideais para quem ocupa ou pretende ocupar essa função e, consequentemente, para o desenvolvimento pessoal e organizacional. Nesse sentido, considerando as competências inseridas no ambiente organizacional das instituições públicas federais de ensino, fica evidente a necessidade de uma maior profissionalização da gestão, além de se tratar de uma questão de exigência legal. O Decreto $\mathrm{N}^{0}$ 5.707, de 23 de fevereiro de 2006, exige a implementação de uma política de desenvolvimento de pessoal nos órgãos e entidades da administração pública federal direta, autárquica e fundacional, com o intuito de melhorar o desempenho através de processos gerenciais orientados para o desenvolvimento de uma gestão por competência.

O presente trabalho tem sua importância na medida em que busca auxiliar no debate e na prática sobre as possíveis ações que podem ser planejadas e colocadas em prática, como na escolha para o cargo de Direção Geral dos campi e direcionamento de investimentos com o intuito de desenvolver as práticas gerenciais dos futuros e atuais diretores gerais de campus dos Institutos Federais de Educação, Ciência e Tecnologia.

\subsection{Estrutura geral do estudo}

O presente estudo está estruturado de forma a facilitar o entendimento do problema de pesquisa, dos objetivos a alcançar para dar resposta a interrogação, da teoria e de pesquisas que já foram elaboradas sobre o tema em questão, assim como dos meios escolhidos para alcançar os objetivos, além de relatar os resultados dos dados obtidos e as conclusões a que o estudo chegou.

Dessa forma, este trabalho está organizado em cinco seções, incluindo esta introdução que abrange a temática e conceitos relativos ao contexto da pesquisa que servem para garantir um entendimento inicial do problema de pesquisa, dos objetivos a serem atingidos, além de desvendar a fundamentação teórica básica com a qual se buscará alcançar os resultados, deixando claro ainda as justificativas teóricas e práticas da presente pesquisa. Na seção 2 discutem-se as principais teorias, conceitos e contribuições a cerca do objeto de estudo e do assunto competência, de maneira geral, passando pelas competências gerenciais e 
terminando com a descrição completa da abordagem de valores concorrentes, além de especificar estudos empíricos que utilizaram o framework adotado. A seção seguinte descreve-se os aspectos metodológicos adotados, ressaltando-se a natureza descritiva através de uma abordagem quantitativa, tendo como sujeitos de pesquisa, ocupantes da função de direção geral de campi dos institutos federais de educação.

Na seção 4 são apresentados os resultados obtidos e discutem-se esses dados com base nos objetivos da pesquisa. Realiza-se em um momento inicial analise preliminar dos dados obtidos, em seguida uma análise exploratória e fatorial confirmatória do modelo adotado e por fim são descritas as variáveis mensuráveis do modelo, assim como suas variáveis latentes, construindo finalmente uma configuração do perfil de competências gerenciais dos sujeitos pesquisados.

Por fim, na seção 5 são ressaltadas as considerações finais e conclusões nas quais a pesquisa chegou, com base na fundamentação teórica adotada e confrontada com os resultados obtidos, descreve-se o perfil de competência gerencial dos diretores gerais de campi dos institutos federais, ressaltando-se a importância de cada modelo para as atividades diárias desses sujeitos, assim como sugestões de mudanças e proposições sobre possíveis estudos a serem realizados, a partir dos resultados alcançados. 


\section{FUNDAMENTAÇÃO TEÓRICA}

Hair Jr. et al. (2005) afirmam que teoria se refere a um conjunto de assertivas sistematicamente relacionadas, que incluem generalizações semelhantes a leis que podem ser testadas na prática. Para esses autores as teorias fornecem percepções importantes para o processo de pesquisa, além de auxiliar na definição da questão de pesquisa.

O referencial teórico deste estudo tem como objetivo abordar os conceitos de competência elaborados e discutidos pelos principais autores com o intuito de situar e não exaurir os debates a cerca da temática. Nesse ínterim é crucial caracterizar a gestão por competências, como sendo uma forma sistemática de praxi gerencial no intuito de desenvolver competências em determinada organização, sendo uma etapa importante para entender a dinâmica da aplicabilidade da abordagem de competências no setor público e consequentemente nos Institutos Federais de Educação.

Nesse sentido, essa descrição inicial se apresenta oportuna como uma introdução aos conceitos sobre competência gerencial, objeto direto deste estudo. Além disso, busca-se nesse tópico descrever o contexto de atuação do gestor público frente às demandas que vem surgindo nos últimos anos, justamente por serem as competências gerenciais nos Institutos Federais de Educação - IF's, objetivo a alcançar deste trabalho. Faz-se necessário, também, que se entenda o modelo da abordagem de valores concorrentes de Quinn et al. (2015).

\subsection{Competências: reflexões iniciais}

O que significa competência? O mínimo que se pode afirmar é que há divergências e correntes de pensamento que enfatizam um ou outro aspecto quanto ao seu exato significado. Dessa forma pretende-se aqui resgatar suas primeiras definições e comparar com a 'evolução' do referido conceito até os dias atuais. Na medida em que foram sendo sistematizados teorias e propostas através dos estudos científicos e as práticas organizacionais foram incorporando a ideia, o termo competência foi ganhando força e notoriedade naqueles espaços. Dessa forma torna-se importante resgatar as descobertas e contribuições do movimento das competências como parte importante para o entendimento das competências gerenciais.

A competência no âmbito das teorias organizacionais está relacionada a duas grandes correntes de pensamento: a primeira, afirma que a competência é importante no nível estratégico das organizações, pois potencializa um diferencial no desenvolvimento de 
competitividade, contribuindo como referência e priorização da gestão. A segunda, genericamente mais conhecida, foca a noção de competências como referência para as práticas da gestão de pessoas nas organizações, no intuito de evidenciar que é necessário buscar novas referências de como lidar com o trabalho levando em consideração toda a complexidade do ambiente (DUTRA; FLEURY; RUAS, 2008).

O assunto de competências tem sido um tema de análise e de estudo desde os anos de 1950. O movimento competências começou a ganhar um impulso importante através das obras introduzidas por McClelland (1973). Desde então, tem havido uma série de estudos realizados sobre o assunto, sendo que a maior parte da literatura as investigações incidem principalmente sobre as competências de gestão ou de liderança e modelos de competência.

A expressão competência, utilizada no dia a dia está diretamente relacionada a uma pessoa que faz bem o que se espera que ela realize, dita competente. O termo competência refere-se a uma característica subjacente de uma pessoa que resulta em um desempenho eficaz ou superior (ARMSTRONG; TAYLOR, 2014). A figura de liderança na definição e popularização do conceito de competência foi Richard Boyatzis (1982). Ele conduziu uma pesquisa que estabeleceu que não havia nenhum fator isolado, mas uma série de fatores que diferenciaram um desempenho bem sucedido do menos sucedido. Esses fatores incluem as qualidades pessoais, motivações, experiência e características comportamentais.

Conforme demonstrado na figura 01, Fleury e Fleury (2001, p.188) ao trabalharem a noção de competência, interrelacionando as correntes americana e europeia, definiram o termo competência como sendo "um saber agir responsável e reconhecido, que implica mobilizar, integrar, transferir conhecimentos, recursos e habilidades, que agreguem valor econômico à organização e valor social ao indivíduo”.

Figura 01: competência como fonte de valor para o indivíduo e para a organização

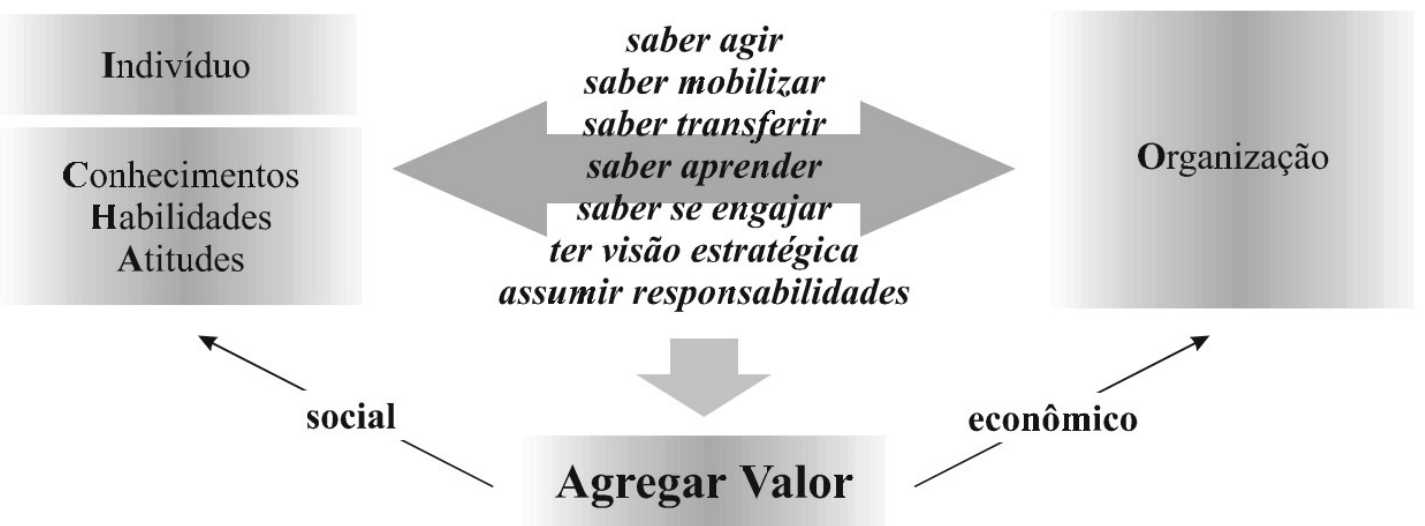

Fonte: Fleury; Fleury (2001, p.188) 
Para entender realmente o que significa competência e mobilizá-la conscientemente, Zarifian (2001) afirma que é necessário a combinação de três abordagens: (i) tomar iniciativa e assumir responsabilidade diante de determinada situação; (ii) entendimento prático de situações que se apoiam em conhecimentos adquiridos e os transforma na medida em que aumenta a diversidade das situações; (iii) ter a capacidade de mobilizar redes de sujeitos em torno das mesmas situações, fazendo com que esses compartilhem as decorrências de suas ações (ZARIFIAN, 2001).

Para Loufrani-Fedida (2011) competência pode ser compreendida como a capacidade de um indivíduo ou de um trabalho coletivo ou de uma organização de mobilizar e combinar recursos (conhecimentos, habilidades e comportamentos) com o intuito de implementar uma atividade ou um processo de ação em particular.

Spencer Jr. e Spencer (1993) definiram competência como uma característica implícita de um indivíduo que está relacionada com algum critério de referência efetiva e/ou desempenho superior no trabalho ou em algum outro contexto. Para eles, essas características (motivos, traços, auto-conceito, conhecimentos e habilidades) subjacentes das pessoas, indicam maneiras de se comportar ou pensar, que podem se tornar genéricas devido as situações e perdurarem por um longo período de tempo (SPENCER; SPENCER, 1993).

Para Quinn et al. (2003), competência requer não só a aquisição de conhecimento, como também uma capacidade comportamental de como agir corretamente. Para tanto não basta tão somente buscar o conhecimento teórico, é indispensável, também, colocá-los em prática, somente assim o gestor estará desenvolvendo determinadas competências.

Boyatzis (2008) define competência como uma capacidade ou habilidade. Para ele a competência é um conjunto de conjuntos de comportamento relacionados, mas diferentes, organizados em torno de uma construção subjacente, que a chama de "intenção". Os comportamentos são manifestações alternativas da intenção, conforme apropriado em várias situações ou momentos (BOYATZIS, 2008).

Para Ceitil (2007) existem dois tipos de competências: as transversais e as específicas. As transversais diferenciam-se das específicas por serem comuns a vários contextos, não tem especificidades, podem ser transferíveis e exercidas em qualquer outro ambiente ou situação. Já as específicas estão associadas diretamente a um emprego, a uma profissão ou a uma função, sendo hierarquizadas. O próprio autor pondera para o que se chama de competências, afirmando que o ideal é que os funcionários não exerçam somente suas atividades relacionadas a sua função, mas também que haja iniciativa, que assumam novas responsabilidades, desenvolvam novos conhecimentos técnicos, de gestão, 
comportamentais, entre outros, desta forma as pessoas estariam mais motivadas (CEITIL, 2007).

Em um contexto organizacional, de trabalho, as competências são definidas, especialmente em razão das atividades e função que serão desenvolvidas. Para tanto, cada comportamento relacionado a uma determinada competência exigida é produzido pelo efeito dos componentes da competência, formando uma sistematização de todos os componentes da competência no desempenho de uma determinada função (CEITIL, 2007).

Apresenta-se os referidos e essenciais componentes da competência, conforme Ceitil (2007) e evidenciado na figura 02: SABER: é o conjunto de conhecimentos que fazem com que os indivíduos que estão exercendo determinada função realizem os comportamentos associados às competências; SABER-FAZER: é o conjunto de habilidades e destrezas que permitem a pessoa ser capaz de colocar em prática os conhecimentos que possui na resolução de problemas que surgem na dinâmica de realização de suas atividades na organização; SABER-ESTAR: está diretamente ligado com as atitudes e interesses do indivíduo que está exercendo determinada função, com eficiência e eficácia, levando em consideração as normas e regras da organização, assim como do seu grupo de trabalho em particular; QUERERFAZER: o ocupante da função deve necessariamente querer realizar e desenvolver os comportamentos indispensáveis das competências, o aspecto motivação é a base de sustentação desse componente; PODER-FAZER: implica de possuir os meios e os recursos necessários na organização para desempenhar os comportamentos relacionados às competências.

Figura 02: os cinco componentes da competência

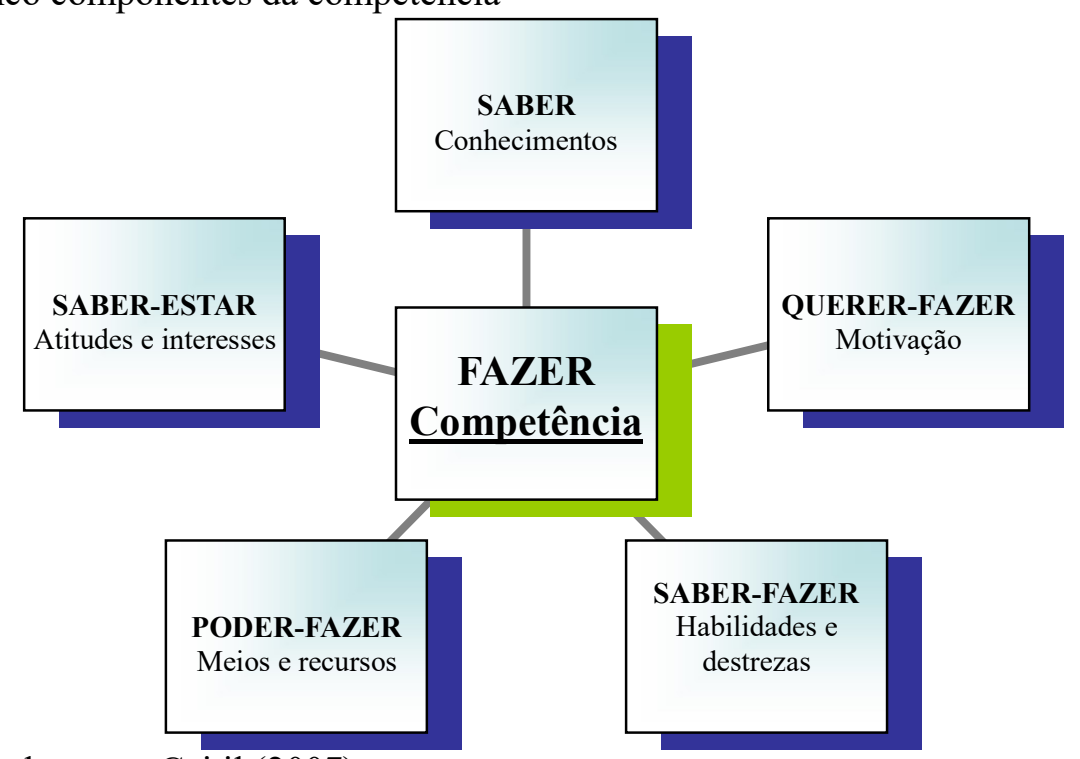

Fonte: autor, com base em Ceitil (2007) 


\subsection{Competência e a especificidade do setor público}

Conforme Hondeghem, Horton e Scheepers (2006), na década de 1980, nos EUA e no Reino Unido surgiu, inicialmente, a ideia de gestão por competências no setor privado, com o intuito de responder as demandas novas que surgiram a partir das transformações econômicas que estavam acontecendo devido a globalização, à concorrência mais forte e ao avanço das tecnologias. Nesse mesmo sentido e no mesmo contexto, acontecem as primeiras iniciativas no setor público: nos EUA, com a ideia do governo empreendedor (Entrepreneurial or Re-engineered Gouvernement) e a inserção, no Reino Unido, da Nova Gestão Pública (NGP, New Public Management), onde a gestão por competências, andando paralelamente a esses movimentos, busca dar respostas aos entraves que surgiram após esse contexto de transformações culturais e organizacionais que estavam ocorrendo (HONDEGHEM; HORTON; SCHEEPERS, 2006).

A partir de então, com o crivo da OCDE, os países europeus iniciam uma tendência para a utilização da abordagem por competência, pois aqueles começam a levar mais em consideração as competências do que os diplomas, entendem que a gestão por competências leva a mudanças nas organizações públicas transformando-as em modernas e flexíveis, além disso, a gestão por competências é colocada como resposta efetiva aos problemas que surgem, pois é com ela que as pessoas se tornam protagonistas, são os indivíduos, com suas competências, que fazem a diferença entre as organizações (HONDEGHEM; HORTON; SCHEEPERS, 2006).

Ceitil (2007) afirma que a gestão por competências surge em um contexto de mudanças, onde o processo de globalização, que integra, que criou uma nova realidade organizacional, trouxe consigo novos desafios, assim em face desse novo cenário a gestão das competências visa uma nova interação entre a organização e as pessoas, no intuito de promover a participação, o envolvimento e o comprometimento, sendo uma tendência forte para construir essa nova realidade organizacional.

Diante desse contexto de exigências da globalização as organizações tendem a criar estruturas organizacionais que possam ser capazes de serem excelentes em seus processos funcionais, assim como que seus funcionários desenvolvam comportamentos compatíveis com esses processos, que sejam eficientes. No ambiente em que estamos, de mudanças rápidas, de complexidade das funções, de exigências cada vez maiores, essa relação entre organização e indivíduos nem sempre é fácil conseguir eficiência, pois quanto maior a 
complexidade dessa função, mais complicado se torna identificar quais competências são realmente indispensáveis para alcançar o sucesso (CEITIL, 2007).

Dessa forma, são as pessoas o principal foco das estratégias organizacionais, pois é nelas que está o alicerce do diferencial entre as organizações, é nessa base que se deve investir para conseguir destaque e se manter em uma posição privilegiada. Distinguir desempenho médio ou inferior de superiores e conseguir determinar quais os comportamentos que são necessários para se chegar a esse desempenho superior dos colaboradores é uma vantagem competitiva de inquestionável valor que a gestão por competências traz consigo no atual cenário organizacional (CEITIL, 2007).

Em um contexto de mudanças em que as organizações estão inseridas é essencial a participação das pessoas na busca por melhorias organizacionais, porém, não basta tão somente se comprometer em buscar resultados e se envolver nas tomadas de decisões e no trabalho em si, requer qualificação e capacitação. E é nesse ínterim que a gestão por competências assume seu valor (BITENCOURT, 2004).

Modelos de competência são frequentemente derivados de uma teoria com base em um conjunto de características desejadas de um gerente ou de um determinado trabalho/função. Alguns modelos de competências vêm da aceitação e perpetuação de traços da cultura organizacional. Estas tradições podem muitas vezes se materializar a partir de uma organização de atitude e mentalidade cultural que têm sido historicamente um mantra para o seu sucesso e que se manifestam em declarações organizacionais, na maneira como as ações são colocadas em prática (BOYATZIS, 1982).

Para Vaishya, Jha e Srivastava (2016), o intuito de um modelo de competência é descrever a combinação de conhecimentos, habilidades e características, necessárias para executar eficazmente um papel em uma organização, podendo ser usada como uma ferramenta de gestão de pessoas, na maior parte de suas funções, como recrutamento e seleção, treinamento e desenvolvimento, avaliação de desempenho, planejamento de carreira etc.

Portanto, a gestão por competências constitui-se um verdadeiro "estilo de vida de uma organização que planeja sua força de trabalho, recruta e seleciona talentos, avalia o desempenho individual, reconhece, promove, remunera e substitui seus executivos, gerentes e colaboradores com base em competências" (CAPUANO, 2015, p.392). 
Capuano (2015) buscou entender quais seriam os contextos e os propósitos dos governos da Bélgica, dos Estados Unidos, da França e do Reino Unido ao adotarem a gestão por competências e chegou a conclusão que as experiências desses países na adoção do modelo de gestão por competências no setor público foi impactada por um contexto nacional de crise econômica, foi impulsionada por uma vontade política de mudanças nos modelos de gerir a coisa pública e por uma preocupação especial desses governos com os níveis executivos e gerenciais, pois entendiam que o desenvolvimento de lideranças (gestores) seria de suma importância para a mudança.

Guimarães (2000) afirma que colocar em prática os preceitos da abordagem por competência no setor público é ativar um processo de transformação das organizações que fazem parte desse contexto. Existem duas questões a serem mencionadas, conforme o autor, em relação à gestão por competências no serviço público: a primeira é que o uso dessa abordagem resultará em uma prestação de serviço público muito mais eficiente, além de flexibilizar e inovar os modelos de gestão das organizações públicas; segundo, porém, a mesma gestão por competências pode reforçar uma exclusão social, o que pode ser superado com ações que envolvam requalificação e redistribuição de mão de obra (GUIMARÃES, 2000).

\subsubsection{O contexto da gestão pública brasileira}

Os desafios da gestão pública brasileira não são diferentes. A administração pública brasileira possui características específicas que foram construídas ao longo da história, as quais podem ser entendidas levando em consideração três dimensões: um modelo de carreiras dos servidores que permeia entre tentativas de consolidação de carreiras tradicionais e um modelo mais flexível, gerando consequências ruins para os servidores e para a gestão em si das organizações públicas em todo o Brasil; o modelo de federalismo adotado no Brasil causa uma substancial disparidade de direitos, salários e requisitos para o exercício da função pública; uma terceira dimensão está associada ao ambiente em que a administração pública brasileira está inserida, um perfil socioeconômico com desigualdades e problemas sociais não atendidos pelas políticas públicas (AMARAL, 2006).

O serviço público brasileiro possui algumas características institucionais problemáticas que merecem avaliação em um contexto de adoção da gestão por competências, como por exemplo, a ética pública no que se refere a promoção de servidores, ao preenchimento de cargos de alta gestão nas organizações, ao modelo geral de recrutamento e 
seleção de candidatos para as carreiras no setor público baseado no instituto do concurso público que não avalia completamente a competência do candidato e não dar chance para a seleção de perfis para função executiva e gerencial (CAPUANO, 2015). Continua Capuano (2015) afirmando que o aparente conflito, imposto pelas regras, entre competências de cargos e postos de trabalho é um fator que leva a um entrave na adoção da gestão por competências no setor público brasileiro e que, conforme esse autor, não há um modelo genérico de competências aplicável a qualquer organização pública.

Nesse sentido Cotrim Filho e Farias (2013), relatam que há um debate crescente nas organizações públicas no sentido de discutir novos meios e possibilidades de gestão que possam contribuir com uma maior efetividade na entrega de políticas públicas perante a escassez de recursos e com vistas a prestação de serviços com qualidade. As mudanças que vem ocorrendo estão exigindo do Estado uma forma de atuar diferente, no sentido de buscar uma melhoria na gestão pública para torná-la dinâmica, flexível e desburocratizada. Esses mesmos autores acrescentam que, nesse contexto de mudanças, a gestão pública brasileira deve ser voltada para resultados, visando três aspectos principais: foco no cidadão, na prestação de serviços com qualidade e no capital intelectual das pessoas (COTRIM FILHO; FARIAS, 2013).

Para Amaral (2006) a administração pública brasileira tem necessidade de gerir com mais propriedade as políticas públicas e isso passa pelo aperfeiçoamento permanente dos servidores, em especial os gestores. Atualmente é indispensável que o gestor público tenha a competência de implementar políticas publicas, gerir recursos e pessoas, alcançar os resultados desejados e tomar decisões, buscando eficiência, eficácia e efetividade na prestação dos serviços públicos a sociedade. Dessa forma, essas pessoas que estão a frente das organizações públicas exercem um papel importante, são elas que têm a missão de coordenar e implementar as atividades de interesse público. Neste contexto, os gestores públicos são peças fundamentais para o desenvolvimento das organizações, ficando evidente a necessidade desses possuírem um perfil de competências adequado ao papel que desempenham (AMARAL, 2006). Para Matias- Pereira (2012) é necessário fortalecer o papel do gestor público diante do contexto de mudanças no estado e na administração pública, resultado da intensificação das transformações ocorridas nos campo político, econômico social, cultural, ambiental e tecnológico nas últimas três décadas. Kanaane, Fiel Filho e Ferreira (2010) reforçam esse argumento afirmando que o gestor assume um papel especial no processo de adaptação organizacional às mudanças do mundo atual.

Pereira e Silva (2011) ressaltam que o alcance de melhores resultados na gestão 
pública podem ser conseguidos através de uma busca pelo profissionalismo e pela possibilidade de se realizar interligação entre competências individuais dos servidores e as estratégias de cada organização pública, no entanto, há de se avançar no quesito competências gerenciais necessárias aos cargos ocupados pelos servidores públicos. Desenvolver melhores práticas de trabalho, melhorar a resolução de problemas e aumentar o desempenho, seriam caminhos que os gestores poderiam conseguir desenvolvendo competências dos servidores, ganhando, com isso, uma oferta de serviço de qualidade e efetividade no uso dos recursos públicos destinados as instituições públicas de ensino, como consequência teria um aumento de suas funções sociais (PEREIRA; SILVA, 2011).

Os diferentes contextos organizacionais e os diversos conjuntos de atribuições e responsabilidades das pessoas (dos gestores) são fatores que exigem categorias de competências específicas para cada situação (DUTRA, 2013). Glória Junior, Zouain e Almeida (2014) ao descreverem as competências técnicas e habilidades necessárias para um perito criminal da Polícia Federal brasileira quando esse exerce a função de gestor, concluíram que a capacidade de trabalhar sob pressão, o dinamismo, a iniciativa, a liderança, o relacionamento interpessoal, a tomada de decisão, a integridade e a cultura de qualidade são competências técnicas e habilidades evidenciadas como de suma importância para que a própria Polícia Federal, como organização, procure estimulá-las e desenvolvê-las pensando nos sujeitos que estão exercendo esse cargo de gerência, assim como os que pensam em assumir futuramente essa função de chefia.

Já Moraes, Borges-Andrade e Queiroga (2011) identificaram competências relevantes para a função de prefeito e secretários municipais. Para esses autores existem dois grupos de fatores indispensáveis na formação de indivíduos que tenham assumido as referidas funções ou que pretendam assumi-las: o primeiro refere-se a realizar a gestão tecno-política, através de conhecimentos da administração pública e da habilidade de captar recursos, e da racionalidade política; já o segundo fator agrupa todos os itens relativos a atitudes, o qual foi denominado de "ter uma atitude democrática e republicana", onde aparecem aspectos relativos aos valores democráticos e aos princípios republicanos, e também, itens relativos ao aprendizado contínuo e ser proativo em relação aos problemas do município. Dessa forma os autores identificaram essas competências relevantes ao exercício dessas funções no âmbito da gestão pública municipal, propuseram e validaram uma escala que pode medir essas competências (MORAES; BORGES-ANDRADE; QUEIROGA, 2011).

Continuando a exemplificar com os achados de estudos empíricos que envolveram competências gerenciais no setor público em contextos específicos, pode-se citar Morassutti e 
Grisci (2002), que descobriram que orientação ao cliente, orientação a resultados, negociação e gestão de pessoas são as competências requeridas no âmbito da Caixa econômica Federal e que, também, foram competências que os gestores de Recursos humanos (RH) perceberam como suas, evidenciando-se, dessa forma que todas possuem o mesmo grau de importância e permeiam as ações do cotidiano dos sujeitos.

Portanto, exemplificado por esses estudos, o setor público deve ser visto com suas características distintivas já que a gestão por competências no setor público tem como consequência um aumento das responsabilidades dos gestores, assim, esses sujeitos devem saber lidar com as incertezas, correr riscos, aprender coletivamente, questionar a si mesmos e aprender com as experiências (AMARAL, 2006).

Alguns estudos empíricos encontrados em pesquisas realizadas relatam essa realidade e evidenciam como as competências gerenciais estão sendo postas na realidade educacional pública brasileira. Como por exemplo, Fleck e Pereira (2011) tendo como objeto de estudo professores coordenadores de programas de pós-graduação de Instituições Federais de Ensino Superior (IFES) do Rio Grande do Sul, constaram que o perfil de competências gerenciais desses professores, genericamente indica uma grande preocupação com o bom desenvolvimento das atividades e com o crescimento do curso no qual atua, além de se mostrarem mais voltados e direcionados para administrar tarefas. Verificou-se ainda que os professores gestores de áreas com características mais objetivas e científicas tendem a se preocupar mais com a administração do trabalho e/ou execução das tarefas, já os gestores de programas com características mais subjetivas, apresentam relação mais intensa com a necessidade de administrar relações (FLECK; PEREIRA, 2011).

Pereira e Silva (2011) em seu estudo no âmbito das Instituições Federais de Ensino Superior identificaram 17 (dezessete) competências gerenciais necessárias aos gestores desse tipo de organização pública, dentro de quatro dimensões: competências cognitivas, funcionais, comportamentais e políticas.

Ésther (2011) admite, a partir das conclusões do seu estudo, que os reitores de universidades federais necessitam, especialmente e suficientemente, de capacidade política, dentre as competências prescritas para o gestor público em geral. Embora que os resultados deixem claro que o desconhecimento das questões administrativas seja um entrave e que não há nenhuma preocupação com a formação e o desenvolvimento das pessoas que ocupem esse cargo e desempenhem sua função efetivamente. 


\subsection{Competência e suas dimensões}

Zarifian (2001) ao tratar das transformações dos conteúdos profissionais e das ocupações, classificou e diferenciou competência em uma organização em cinco grupos:

i) competências em processos: domínio sobre o fluxo dos processos de trabalho;

ii) competências técnicas: entendimento de como integrar os objetivos estabelecidos pela organização, nos atos técnicos, quando assume responsabilidade em um trabalho que deve ser realizado.

iii) competência sobre a organização: conhecer e organizar os parâmetros e princípios do funcionamento dos fluxos de trabalho;

iv) competência de serviço: avaliar o impacto (benefícios) nos destinatários finais dos produtos/serviços da organização e os problemas ligados a utilização desses produtos/serviços e ao modo de vida dos clientes ou usuários dele;

v) competência social: está relacionada com uma perspectiva comportamental no campo da autonomia, do assumir responsabilidade e da comunicação.

Segundo Ruas (2005), o entendimento da noção de competência é um processo heterogêneo tanto nas pesquisas quanto na prática organizacional e que deve ser vista a partir de suas dimensões: organizacionais, funcionais e individuais/gerenciais. A emergência desses conceitos parte de contextos históricos e momentos diferentes, a perspectiva individual de competência situa-se em um extenso debate ocorrido nos anos de 1960 e 1980 o qual a associavam a noção de qualificação, já a competência vista numa perspectiva mais estratégica tem sua origem mais recente, especialmente com o conceito de core competence de Hamel e Prahalad (1995).

A competência organizacional está intimamente associada à estratégia competitiva das organizações e seus elementos (RUAS, 2005) e Hamel e Prahalad (1995), defendem que as competências essenciais (core competences) são a fonte do desenvolvimento de novos negócios, pois são proporcionadas pela aprendizagem coletiva na organização, especialmente como coordenar diversas habilidades de produção e integrar múltiplos fluxos de tecnologias. Para esses autores pelo menos três testes podem ser aplicados para identificar competências essenciais em uma organização: primeiro, uma competência essencial fornece acesso potencial a uma ampla variedade de mercados; em segundo lugar, deve fazer uma contribuição significativa para os benefícios percebidos pelo cliente em relação ao produto final; e finalmente, uma competência essencial deve ser difícil para os concorrentes imitarem (PRAHALAD; HAMEL, 1990). Nesse sentido as core competence exigem condições 
epecíficas para serem alcançadas e destarte a sua concepção original, acabam sendo um tipo especial de competência organizacional difícil de ser atingida, porém proporciona um amplo diferencial competitivo (RUAS, 2005).

Em uma dimensão intermediária surgem as competências funcionais, situadas no nível das grandes funções ou macroprocessos das organizações, ou seja, funções coletivas das organizações como conceber e produzir produtos/serviços, obter insumos e/ou informações, gerenciar a manutenção e a logística e gerir os recursos tangíveis ou não das organizações, seriam competências com atribuições mais relacionadas a grupos específicos com responsabilidades funcionais, o que não deixa de valer para toda a organização (RUAS, 2005). Dessa forma, dependendo da organização essa competência mais específica, de um ou mais grupos, pode vir a ser uma competência organizacional, como segue afirmando Ruas (2005).

E, focalizando o nível individual, têm-se as competências individuais, as quais, na visão de Ruas (2005), são as ações postas em prática nas organizações advindas das propostas e projetos das competências funcionais. O que se pode observar é que há uma intensa e heterogênea complexidade no modo de enxergar e conceituar as competências individuais, devido a sua maior difusão e semelhanças com outros conceitos, como por exemplo, a noção de qualificação, atribuição e responsabilidade. Genericamente, os conceitos que são verificados na literatura associam competência individual ao desempenho no trabalho e no contexto em que esse indivíduo exerce suas funções. No entanto, como afirmam Fleury e Fleury (2001) a competência do indivíduo não é uma condição e não pode ser restringida a um ou um conjunto de conhecimento específico. Nesse sentido Le Boterf (2003) esclarece, para que a competência individual se torne possível não basta ter os recursos (conhecimentos, capacidades) é indispensável que haja a colocação em prática de um repertório de recursos, isso será resultado, portanto, da articulação de três domínios: o próprio sujeito em si (biografia e socialização), as situações profissionais (o contexto profissional) e as situações de formação (formação profissional).

As competências individuais devem sustentar e se alinharem às competências essenciais previamente estabelecidas, no intuito de serem uma "integração sinérgica das habilidades, conhecimentos e comportamentos, manifestada pelo alto desempenho da pessoa, que contribui para os resultados da organização" (NISEMBAUM, 2000, p.91). Nesse sentido, considerando que as competências organizacionais se desdobram em competências coletivas e individuais, podem-se definir e entender quais os conhecimentos, habilidades e atitudes esperadas dos gestores enquanto competências gerenciais (MOURA; BITENCOURT, 2006). 


\subsubsection{Competências gerenciais}

O gerente há um tempo tem sido tema de investigações e debates de vários estudiosos em todo o mundo. No início do século XX, Henri Fayol foi um dos estudiosos pioneiros a considerar a importância da função gerencial no processo administrativo e indicar uma lista de deveres que levaria o gestor a ser eficaz. Chester Barnard, já no anos de 1930 expõe em seu livro "The functions of the executive", a importância da interação comunicacional entre a organização formal e a informal e descreve as funções, os processos e as responsabilidades do executivo. O clássico estudioso Peter Drucker, já na segunda metade do século XX também desenvolveu conceitos sobre gerentes e suas competências. Em um contexto temporal semelhante, Peter Simon enfatiza que o cerne das atividades gerenciais tem natureza decisória. Em seguida, no nos de 1960 aparecem Black e Mouton que desenvolveram o modelo da "grade gerencial". Outro autor que contribuiu efetivamente para a dimensão gerencial foi McGregor com sua "Teoria X e Y" a qual prescrevia que a ação dos gerentes é influenciada por suas concepções a cerca do comportamento humano. Likert, nos anos 1970, também aparece nesse rol com sua proposição dos estilos de sistema de liderança. Já Mintzberg contribuiu nesse contexto propondo que os gerentes exercem atividades que podem ser classificadas em 10 (dez) papeis gerenciais (papel de chefe, de coordenador, de líder, de monitor, de disseminador, de representante, de empreendedor, de manipulador de distúrbios, de alocador de recursos e papel de negociador) dentro de um conjunto de papeis interpessoais, papeis de informação e papeis de decisão. Há também o Katz que propôs uma divisão das habilidades gerenciais em habilidades técnicas, humanas e conceituais.

Quando se busca a origem do termo "competências gerenciais" as referenciais recaem sobre Richard Boyatzis. A expressão foi colocada em um estudo pela primeira vez em 1982, através da publicação do seu livro "The Competent Manager: A Model for Effective Performance", iniciando assim esse debate propriamente dito. Nesse livro Boyatzis (1982) apresenta os resultados de um estudo sobre as características que estariam associadas ao desempenho efetivo dos gestores, construindo um modelo de perfil ideal de gestor, baseado em 6 (seis) grupos de competências associadas a 21 (vinte e um) atributos, conforme segue: I - Metas e gestão pela ação: (1) orientação eficiente; (2) produtividade; (3) diagnóstico e uso de conceitos; e (4) preocupação com impactos;

II - Liderança: (5) autoconfiança; (6) uso de apresentações orais; (7) pensamento lógico; (8) conceitualização;

III - Recursos Humanos: (9) uso de poder socializado; (10) otimismo; (11) gestão de grupo; 
(12) auto avaliação e senso crítico;

IV - Direção de subordinados: (13) desenvolvimento de outras pessoas; (14) uso de poder unilateral; (15) espontaneidade;

V - Foco em outros cluster: (16) autocontrole; (17) objetividade perceptual; (18) adaptabilidade; (19) preocupação com relacionamentos próximos;

VI - Conhecimento especializado: (20) memória; e (21) conhecimento especializado.

Boyatzis (1982) tinha como base a concepção behaviorista (comportamental), em que essas vinte e uma competências diferentes poderiam ser analisadas em termos de níveis (motivacional, autoimagem e papel social e habilidades) e conseguir fazer com que as organizações, sejam elas públicas ou privadas, conseguissem melhores resultados, considerando-se, consequentemente, a importância da formação gerencial. Assim, a partir dessas conclusões Boyatzis inaugurava uma ruptura com alguns conceitos.

Outros importantes autores, Lyle M. Spencer Jr. e Signe M. Spencer, no ano de 1993, destacaram a importância das competências gerenciais, afirmando que essas são um subconjunto especializado das competências de impacto e de influência, com o intuito de conseguir determinados efeitos específicos, tais como desenvolver outros, liderar outras pessoas, melhorar o trabalho em equipe e a cooperação, tornando-se uma particularidade importante para os gestores (SPENCER Jr.; SPENCER, 1993).

No contexto atual o gerente (gestor) assume, também, um papel preponderante e de suma importância, pois é ele que interliga a busca pelo alcance dos objetivos organizacionais e as competências individuais (algo maior que qualificação profissional), dessa forma fica nítida a importância das competências gerenciais como forma de análise do trabalho dos gestores (BÜNDCHEN; ROSSETTO; SILVA, 2011).

Levando em consideração que os resultados alcançados pelos gestores influenciam as competências ou o desempenho dos seus subordinados e, consequentemente, sobre os resultados organizacionais, as competências gerenciais têm despertado interesse dos teóricos, das organizações e de pesquisadores (BRANDÃO, 2009). Esse interesse tem sido evidenciado, principalmente, pela busca constante das organizações acompanharem as mudanças que estão acontecendo no mundo atual, onde são exigidos novos perfis de profissionais capazes de lidar com essas imprevisibilidades do mundo do trabalho, assim, o resultado do trabalho é muito mais valorizado do que a forma como é colocado em prática, deixando evidente que a temática de competências gerenciais é uma alternativa viável a essa conjuntura em constante transformação (PEREIRA; SILVA, 2011). 
Portanto, deve-se perguntar: como adquirir essas competências? O que se deve fazer para acompanhar essa evolução, essas mudanças e contribuir para o resultado organizacional? Alguns autores nacionais trabalham essas questões e afirmam que a aprendizagem organizacional pode ser uma estratégia importante no intuito de desenvolver competências gerenciais, necessitando para tanto um equilíbrio entre as práticas formais e informais nas organizações e que o comprometimento das pessoas seja mais efetivo, buscando-se refletir sobre a questão do autodesenvolvimento (BITENCOURT, 2002).

Kenski e Brunstein (2010) concluiram que o e-learning pode estar a serviço do desenvolvimento de competências gerenciais, ao promover situações de aprendizagem que instiguem e mobilizem à ação. A própria organização tem de desenvolver competências no sentido de superar os limites apresentados e alavancar as possibilidades que a ferramenta oferece. Já Lopes et al. (2010) ao relacionar aptidões cerebrais dominantes com competências gerenciais exigidas em determinados setores de uma empresa, comprovaram forte aderência entre esses construtos, além de verificarem a importância desse conhecimento como instrumento de gestão do capital humano das organizações.

Félix (2005), obteve uma observação importante nessa questão ao avaliar um programa de desenvolvimento gerencial e o impacto do programa na aquisição de conhecimentos e na prática de competências requeridas para a prática do modelo de gestão adotado constatou que o tempo de treinamento influi na aquisição de conhecimento, que os gestores conhecem as características do modelo de gestão (teoria proclamada), mas não as aplicam na mesma proporção (teoria aplicada) e se confirmou a relação entre o uso de mecanismos de defesa organizacionais e a ausência de prática das competências gerenciais requeridas.

De uma forma geral, para Bitencourt (2004), as práticas informais e a necessidade de se estabelecer uma estratégia articulada são importantes na gestão de competências gerenciais, assim como a construção de uma consciência social. A interação entre as pessoas (reflexões que privilegiam o coletivo), a visão processual (desenvolvimento contínuo) e a ênfase na questão pragmática (práticas de trabalho), são elementos da aprendizagem organizacional que contribuem para a gestão de competências gerenciais.

Nesse sentido vale salientar que, ao se analisar os estudos que tem como objeto a temática gerencial, percebe-se, ainda, uma dificuldade em delimitar de forma exata quais seriam os limites, as funções, as prioridades e as perspectivas para o nível gerencial, dessa forma é relevante trabalhos de pesquisa que busquem ampliar esse universo e que contribuam 
para esclarecer as práticas gerenciais nos dias de hoje, seja no âmbito público ou privado (MARRA; MELO, 2005).

Freitas (2016) após revisão de literatura busca uma compreensão de competências gerenciais, afirmando que se trata de comportamentos observáveis ou possíveis de acontecer, os quais são evidenciados os seus conhecimentos, habilidades e atitudes ou a sinergia entre eles, agregando valor a si, aos outros e a organização, conforme o contexto, os recursos e a estratégia.

Já Resende (2000) ao classificar diferentes conceitos e tipos de competências, afirma que competências gerenciais são capacitações (habilidades pessoais e conhecimentos de técnicas de administração ou gerenciamento) mais específicas do nível gerencial aplicadas em quando o indivíduo se encontrar em situações de direção, coordenação ou supervisão.

Competências gerenciais são uma mistura de competências funcionais (tomada de decisões, definição de estratégias) e comportamentais (relações, liderança, aprendizado com os próprios erros, capacidade de motivar, influenciar outros, enfocar resultados e processos, comportamento ético) (NEAGU, 2015).

Levando em consideração aspectos diferentes abordados por alguns autores, a competência gerencial deve ser tratada como um agir através do qual se coloque em prática conhecimentos, habilidades e atitudes pessoais e profissionais com um objetivo a cumprir, em um determinado contexto (RUAS, 2005). Assim, a competência gerencial está muito mais ligada a colocação em prática desses recursos/atributos (saber, capacidades, habilidades) do que especificamente no conceito de recursos/atributos (RUAS, 2000). Apontando para essa inferência o estudo de Godoy e D'Amelio (2012) é importante, pois, ao identificarem, descreverem e analisarem, comparativamente, as competências gerenciais desenvolvidas e utilizadas por gestores de origens profissionais distintas, perceberam que o processo de mobilização e articulação das competências gerenciais se constituiu como um processo dinâmico, contínuo e baseado em sucessivas experiências, integração entre aprendizagem formal e informal. Constataram ainda que, quando os sujeitos passaram da carreira profissional para a gerencial, houve mudança na forma de enxergar o trabalho, sobretudo pelo redimensionamento da responsabilidade.

Para Moura e Bitencourt (2006) focar a busca de um entendimento sobre competências gerenciais tão somente em mensurar atributos (um grupo de competências), privilegia um modelo genérico, aplicável a qualquer organização, independente de suas diferenças culturais. No entanto, Sandberg (1996), contrapondo essa concepção racionalista, propõe um modelo fenomenológico e interpretativo das competências gerenciais, buscando 
avaliar porque determinados atributos passam a ser mais relevantes que outros. Como foi o caso dos resultados encontrados por Baisch et al. (2012), que identificaram um conjunto de competências necessárias ao gestor de marketing para a otimização da gestão estratégica da organização e para um eficiente desempenho de suas funções.

Brandão, Borges-Andrade e Guimarães (2012), verificaram em um estudo sobre agências bancárias, que as competências relativas à gestão estratégica e à gestão financeira dos gerentes revelaram-se preditoras de diferentes dimensões do desempenho das agências. Outras competências (gestão de processos e gestão socioambiental), o número de horas dedicadas a treinamentos e a percepção dos gestores acerca das práticas de gestão de desempenho da empresa (uma dimensão do suporte organizacional) apresentaram efeitos menos abrangentes.

Bündchen, Rossetto e Silva (2011) evidenciaram que as competências gerenciais identificadas e requeridas, na percepção dos gerentes de agências bancárias e consideradas como mais importantes no desenvolvimento de suas atividades foram as competências sociais, quer dizer, as interações humanas foram sinalizadas como importantes para o bom desempenho de suas atividades, porém, esses mesmos gestores acreditam que não recebem apoio para o desenvolvimento proporcional as suas respectivas importâncias, indicando haver aí um "gap" entre a percepção dos gerentes e os programas de encorajamento das competências gerenciais feitos pela organização estudada.

Levando em consideração todo esse contexto de pesquisa empíricas realizadas e estudos teóricos, é importante entender que esse perfil exaltado do gestor do século XXI que contém um determinado conjunto de atributos, não é tarefa de um, mas de um ou mais coletivos de gestores, portanto, é a gestão, como um todo, e não um gestor, individualmente, que deve se mobilizar para alcançar um desenvolvimento e alcançar melhores resultados (RUAS, 2000). Bitencourt (2002) dá a sua contribuição, relatando que para cada organização existe uma lista de atributos para a definição de competência gerencial, e que esses precisam está intimamente ligados com o negócio da organização.

Ferigotti e Fernandes (2014) estudaram gerentes e líderes de projetos, no intuito de examinar as relações entre competências individuais destes, as rotinas/processos organizacionais e inovação tecnológica e chegaram a constatação que não são as competências gerenciais isoladamente consideradas que contribuem para o desempenho em inovação, no estudo de caso, a inovação está sendo desenvolvida a partir de capacidade dinâmica em rotinas organizacionais relacionadas à competência dos gerentes de criar, estender ou modificar a base de recursos da organização, assim a capacidade dinâmica como 
combinação de rotinas/procesos e competências gerenciais é que influencia a inovação quando ocorre a interação entre níveis organizacionais.

Seate, Pooe e Chinomona (2016) ao discutir a essência das competências gerenciais e relacionar as percepções no desempenho do trabalho, a partir da visão de alguns autores, afirmam que essas consistem em conjuntos identificáveis de ações que os indivíduos realizam e que levam a certos resultados. Porém, competência gerencial não é um fenômeno universal que possa ser definido e medido de forma clara e objetiva. Em vez disso, essas competências gerenciais são particularistas, situadas, contextuais e socialmente construídas (SEATE; POOE; CHINOMONA, 2016). Como por exemplo, Sousa e Valadão Junior (2013) identificaram e analisaram que as competências gerenciais contempladas em ementas de disciplinas dos cursos superiores de Administração que contribuem para o desenvolvimento de competências relevantes ao gestor que pretende seguir carreira no exterior são a visão estratégica e capacidade de tomada de decisão.

Seguindo essa linha de raciocínio Pelissari, Gonzalez e Vanalle (2011), analisando o contexto de pequenas empresas, concluíram, a partir de seus estudos que as competências gerenciais, consideradas essenciais na visão dos gestores desse tipo de organização, são eminentemente competências técnica (conhecimento do mercado e monitorar o ambiente) e conceitual (raciocínio abstrato, planejamento, criatividade e inovação e adaptação), visto que consideraram ser de maior relevância para eles enquanto administradores, o conhecimento do negócio da organização e seu ambiente, e a identificação das vantagens competitivas e oportunidades.

\subsection{A abordagem de valores concorrentes na gestão}

Este modelo foi selecionado sobre outros modelos porque este não limita os atributos de melhor gestão de um gerente, mas deixa claro os atributos que são altamente valorizados pelos gerentes eficazes. Além disso, salienta a contribuição positiva de todos os atributos que podem ser necessários em um momento ou outro. Dado que a competência é um fenômeno complexo, que envolve um conjunto de elementos e condições para se desenvolver, para a análise do objeto de estudo em questão, foi utilizado o modelo da abordagem de valores concorrentes na gestão de Quinn et al. (2015). Destaca-se, também, a importância desse framework em pesquisas realizadas em todo o mundo por diversos estudiosos, confirmando a importância dos autores e de suas proposições. Freitas (2016) relatou em sua pesquisa entre os anos de 2005 a 2015 que 12 (doze) estudos sobre competências gerenciais 
tinham como base o modelo de Quinn et al. (2015). É importante destacar que o modelo atual é uma evolução da primeira proposta originalmente produzida pelo autor, no ano de 1988, através de sua obra. Em uma pesquisa simples na base de dados do "Google Scholar" constata-se que o título da obra de Quinn et al. "Becoming a master manager: a competency framework" é citada 1.151 vezes por diversos pesquisadores.

Para Quinn et al. (2015) ser um gestor e líder com mais efetividade em suas ações é uma situação que exige todo um caminhar de aprendizados durante a vida com o propósito de transpassar situações conflitantes, principalmente no que se refere ao processo de aprendizagem. Assim, os autores sugerem que o alcance da efetividade na função de gestor deve ser encarada como uma navegação em um mundo cheio de paradoxos, portanto a abordagem ideal seria a de valores concorrentes na gestão, pois, frequentemente, os gestores são levados a tomar decisões que à primeira vista as opções parecem ser mutuamente exclusivas: pensar no futuro e no presente ao mesmo tempo, realizar mais com menos, estimular a inovação e garantir a estabilidade (QUINN et al., 2015).

Para estes autores a abordagem de valores concorrentes na gestão procura justamente maneiras de ir além desse limites paradoxais existentes e redefinir o que estiver ao alcance. No entanto, existem as crenças, os valores e os pontos de vista que quase todos possuímos e define a maneira de agir, geralmente chamada de modelos nos estudos administrativos, que de certa forma afetam o que acontece nas organizações e seus resultados (QUINN et al., 2015).

$\mathrm{O}$ atual cenário mundial, onde as pessoas, a sociedade e as organizações passam por rápidas mudanças culturais, sociais e tecnológicas, a principal questão que surge é como gerenciar, tomar decisões, em um ambiente tão volátil, complexo e ambíguo. Além disso, têmse dúvidas sobre como obter cooperação, quais as maneiras que se pode conseguir motivação e lealdade sem segurança empregatícia de funcionários. Quinn et al. (2015) afirmam que essas interrogações levam a situação preocupante ainda maior: a necessidade de alcançar efetividade organizacional nesse ambiente e com exigências paradoxais. É nesse ínterim que surge a estrutura de valores concorrentes como uma ferramenta poderosa e testada pelo tempo que pode auxiliar os tomadores de decisão a obter respostas para essas questões.

Para Quinn et al. (2015) a ideia da estrutura de valores concorrentes é dar respostas complexas a essas situações complexas. Em certas ocasiões, as organizações necessitam de estabilidade e outras vezes se beneficiam da mudança. Nesse sentido, indo de encontro à abordagens anteriores, o desenvolvimento da estrutura de valores concorrentes não considera que estabilidade e mudança possam ser mutuamente exclusivas, a ideia é justamente 
eliminar essa suposição e evidenciar que comportamentos contrastantes podem ser necessários e desempenhados ao mesmo tempo. Surge assim, conforme Quinn et al. (2015) o cerne da ideia da estrutura de valores concorrentes, aparentemente paradoxal, mas que considera o modelo de meta racional, o modelo de processo interno, o modelo de relações humanas e o modelo de sistema aberto, como elementos de um modelo integrado maior, como mostra a figura 03 .

Figura 03: estrutura de valores concorrentes: critérios de efetividade

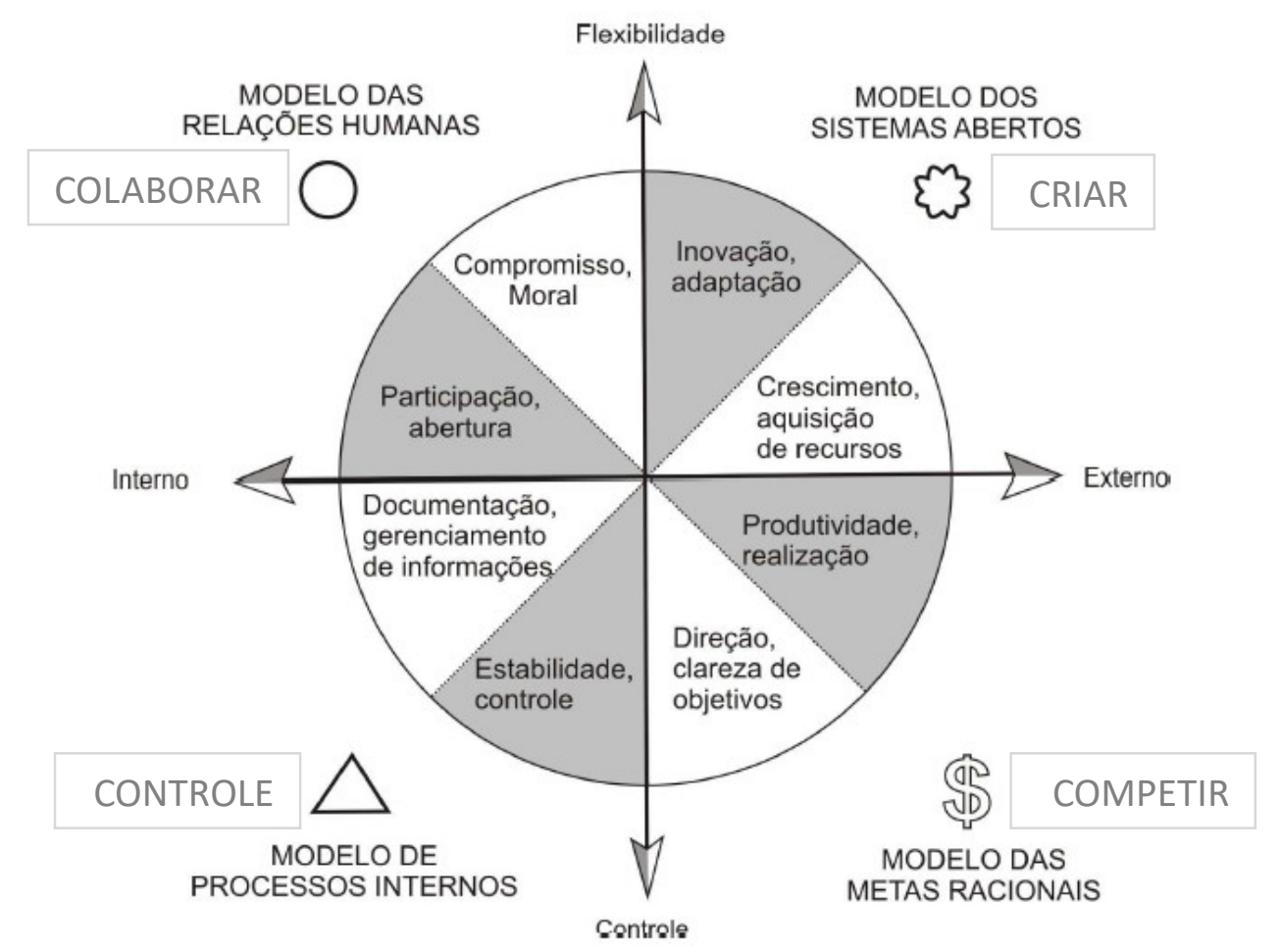

Fonte: Quinn et al. (2015), com adaptações

Os focos de pensamento e valores de cada um dos quatros modelos de gestão (Meta racional, processo interno, relações humanas e sistema aberto) estão encaixados em cada um dos quadrantes e seus inter-relacionamentos podem ser observados em termos dos eixos, onde o vertical varia de flexibilidade na parte superior a controle na inferior e o eixo horizontal varia de um foco organizacional interno à esquerda a um foco externo à direita (QUINN et al., 2015). Conforme demonstrado na figura 03, Colaborar, Controlar, Competir e Criar são estruturas de valores concorrentes, porém, representam tipos de ações em que os gestores necessariamente, precisam se envolver e os modelos dentro da construção da efetividade organizacional estão relacionados e podem ser observados quanto aos dois eixos: o eixo horizontal (que varia de um foco organizacional interno à esquerda a um foco externo à 
direita) e o eixo vertical (que varia de flexibilidade na parte superior a controle na inferior) (QUINN et al., 2015).

Com o intuito de transformar esses quatro modelos teóricos em práticas de gestão os autores conceituaram cada quadrante conforme a ideia central de ação relacionada a cada modelo: Colaborar equivalente ao modelo de relações humanas, Controlar vinculado ao processo interno, Competir para o modelo de meta racional e Criar resultante do sistema aberto. Os valores gerais também são adicionados modelo, enfatizando os contrastes, um oposto perceptivo (QUINN et al., 2015).

Portanto, a inserção e a nítida relação conflitante desses quatro modelos são a base para a discussão de diferentes competências centrais necessárias para uma gestão efetiva, surgindo esse modelo de gerenciamento integrado chamado estrutura de valores concorrentes. A ideia é que esses interesses opostos colocados pelos modelos de gestão possam ser colocados em prática em sistemas reais, representando os valores invisíveis pelos quais pessoas, programas, políticas e organizações vivem e morrem (QUINN et al., 2015).

Colaborar é o imperativo de ação que reflete os valores do modelo de relações humanas, que para ser alcançado deve-se criar e sustentar compromisso e coesão. Nesse sentido espera-se que todos os funcionários busquem comunicação aberta e respeitosa entre si, o que demanda necessariamente profundo entendimento e interesse pelos outros, assim como por si mesmo. As pessoas ao orientar e desenvolver os outros colaboradores, ao gerenciar grupos e liderar equipes acabam beneficiando toda a organização. Nesse item, o que mais se torna importante é que os colaboradores saibam lidar com conflitos, tanto os que geram construções coletivas quanto os que destroem (QUINN et al., 2015). Observadas o modelo de uma forma mais abrangente, como demonstrado no Quadro 01, fica claro o foco, o imperativo de ação a ser adotado pelos gestores nas possíveis situações que venham a acontecer, as competências necessárias para o fator e o que significa cada uma. 
Quadro 01 - competências associadas ao modelo de relações humanas

\begin{tabular}{|c|c|c|c|c|}
\hline Modelo & $\begin{array}{c}\text { Imperativo } \\
\text { de ação }\end{array}$ & Foco & Competências & Definições específicas \\
\hline \multirow{5}{*}{ 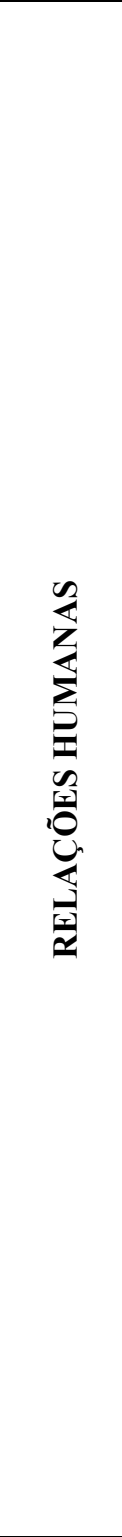 } & \multirow{5}{*}{ 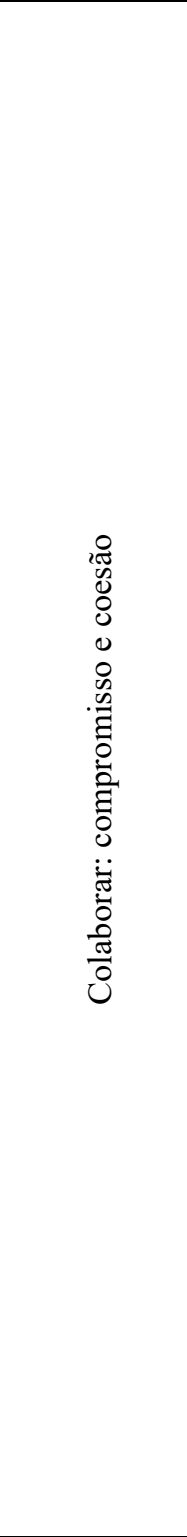 } & \multirow{5}{*}{ 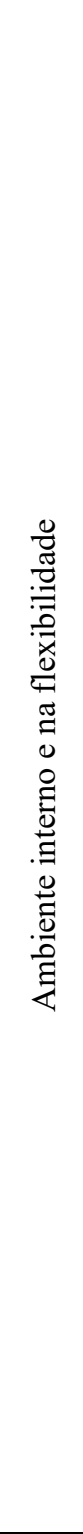 } & $\begin{array}{l}\text { Entender a si } \\
\text { mesmo e os } \\
\text { outros }\end{array}$ & $\begin{array}{l}\text { Reconhecer os sentimentos das pessoas; estar ciente de } \\
\text { quando as pessoas estão se esgotando; Encorajar pessoas } \\
\text { a ter um equilíbrio trabalho/vida; usar escuta empática e } \\
\text { mostrar minha preocupação pelos problemas das outras } \\
\text { pessoas; Trabalhar eficazmente com pessoas cujas } \\
\text { personalidades são diferentes das minhas. }\end{array}$ \\
\hline & & & $\begin{array}{c}\text { Comunicar com } \\
\text { honestidade e } \\
\text { efetividade }\end{array}$ & $\begin{array}{l}\text { Conhecer meu público e ter um claro entendimento de } \\
\text { meu propósito quando eu me comunico; comunicar-se } \\
\text { persuasivamente ao fornecer evidência sólida e } \\
\text { argumentos teóricos fortes que apoiam minha posição; } \\
\text { eliminar ou minimizar barreiras comuns para } \\
\text { comunicação eficaz; expressar minha discordância de } \\
\text { maneira que encorajam a discussão aberta e a resolução } \\
\text { de problemas; perceber pistas não verbais e usar escuta } \\
\text { reflexiva para garantir que eu entendo o que as outras } \\
\text { pessoas estão dizendo para mim. }\end{array}$ \\
\hline & & & $\begin{array}{l}\text { Orientar e } \\
\text { desenvolver } \\
\text { pessoas }\end{array}$ & $\begin{array}{l}\text { Certificar-se de que todos têm um plano para ajudá-los a } \\
\text { desenvolver; Treinar pessoas com problemas } \\
\text { profissionais; Encorajar outros a pensar sobre seu } \\
\text { desenvolvimento profissional; Desenvolver outros ao } \\
\text { delegar tarefas que exigem deles aprender novas } \\
\text { habilidades; Fornecer feedback de desempenho oportuno } \\
\text { que inclui exemplos específicos de comportamentos } \\
\text { desejáveis e não desejáveis. }\end{array}$ \\
\hline & & & $\begin{array}{c}\text { Gerenciar } \\
\text { grupos e liderar } \\
\text { equipes }\end{array}$ & $\begin{array}{l}\text { Manter um ambiente aberto para discussão; Tornar } \\
\text { legítimo para as pessoas contribuir com suas opiniões; } \\
\text { Empregar técnicas de tomada de decisão participativa; } \\
\text { Prestar atenção aos papeis e processos da equipe assim } \\
\text { como as metas da tarefa; Planejar e implementar } \\
\text { reuniões que são produtivas, eficientes, e com a } \\
\text { presença de muitos. }\end{array}$ \\
\hline & & & $\begin{array}{l}\text { Gerenciar e } \\
\text { estimular o } \\
\text { conflito } \\
\text { produtivo }\end{array}$ & $\begin{array}{l}\text { Evitar facilitar prematuramente conflitos construtivos } \\
\text { relacionados à tarefa; Estimular conflito usando grupos } \\
\text { de apoio para encorajar decisões de maior qualidade; } \\
\text { Distinguir entre diferentes fontes de conflito; Usar } \\
\text { diferentes abordagens para o gerenciamento de conflito } \\
\text { dependendo da situação específica; Resolver conflitos } \\
\text { interpessoais destrutivos. }\end{array}$ \\
\hline
\end{tabular}

Fonte: elaborada pelo autor (2018), com base em Quinn et al. (2015)

Controlar refere-se ao estabelecimento e a manutenção da estabilidade e continuidade, diretamente relacionado ao modelo de processo interno. Espera-se que os gestores tenham excelência em entendimento dos mínimos detalhes da organização, especialmente no que se refere a sua unidade, suas regras e metas. Porém, devido à complexidade da maioria das organizações, exige-se que os gestores tenham a capacidade de trabalhar em outra unidade, exercendo outras funções. No controle o papel do gestor está atrelado ao planejamento e a coordenação de projetos que exigem manipulação de dados e formulários, além de revisar e responder informações de rotinas está atento aos acontecimentos diários e preparar revisões de relatórios e outros documentos. Avaliar o 
desempenho quanto à eficiência e quanto à efetividade e fornecer feedback oportunamente $\mathrm{e}$ com relevância são atribuições de quem busca por esse imperativo de ação (QUINN et al., 2015). Segue as especificações do quadro 02.

Quadro 02 - competências associadas ao modelo de processos internos

\begin{tabular}{|c|c|c|c|c|}
\hline Modelo & $\begin{array}{c}\text { Imperativo } \\
\text { de ação }\end{array}$ & Foco & Competências & Definições específicas \\
\hline \multirow{5}{*}{ 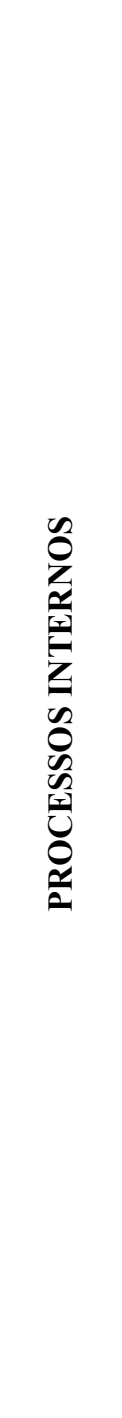 } & \multirow{5}{*}{ 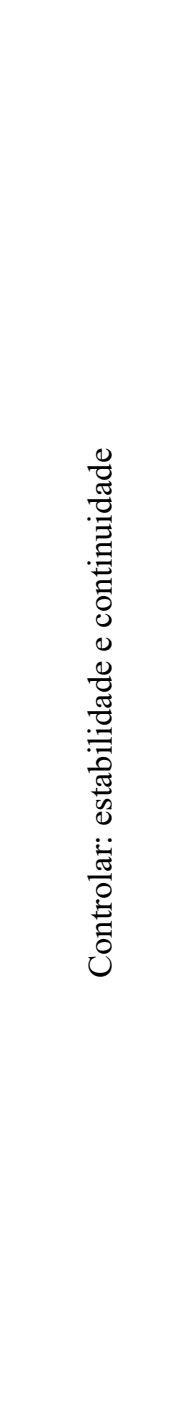 } & \multirow{5}{*}{ 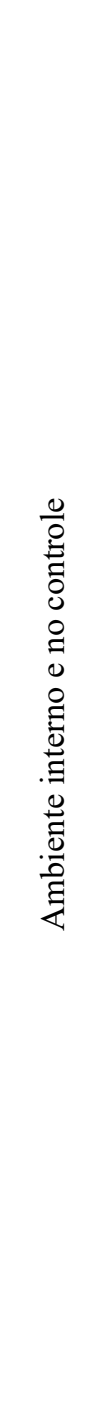 } & $\begin{array}{c}\text { Organizar } \\
\text { fluxos de } \\
\text { informações }\end{array}$ & $\begin{array}{l}\text { Decidir quando uma interação face a face é mais apropriada que } \\
\text { um email, chamada telefônica ou memorando; Gerir mensagens } \\
\text { e materiais que eu recebo eficientemente para que eu apenas } \\
\text { tenha que lidar com eles uma vez; Enviar mensagens eletrônicas } \\
\text { concisas, amigáveis, e mensagens de voz que são eficazes em } \\
\text { fazer os outros responderem pronta e apropriadamente aos meus } \\
\text { pedidos; Priorizar meus itens de ação para que eu gaste a maior } \\
\text { parte do tempo no que é importante, em vez de em coisas que } \\
\text { parecem urgentes mas que não são importantes; Distinguir entre } \\
\text { informação útil e dados que são irrelevante }\end{array}$ \\
\hline & & & $\begin{array}{l}\text { Trabalhar e } \\
\text { gerenciar entre } \\
\text { funções }\end{array}$ & $\begin{array}{l}\text { Escolher as pessoas corretas para trabalhar em uma equipe } \\
\text { multifuncional; Usar equipes multifuncionais para fornecer } \\
\text { integração em uma organização tradicionalmente estruturada; } \\
\text { Superar os desafios das equipes multifuncionais; Capitalizar as } \\
\text { vantagens de usar uma equipe multifuncional; Trabalhar com } \\
\text { sucesso em equipes multifuncionais. }\end{array}$ \\
\hline & & & $\begin{array}{l}\text { Planejar e } \\
\text { coordenar } \\
\text { projetos }\end{array}$ & $\begin{array}{l}\text { Manter projetos sob controle; Gerenciar projetos } \\
\text { cautelosamente; Fornecer administração de projeto rigorosa; } \\
\text { Preparar e usar ferramentas de planejamento de projeto básicas } \\
\text { tais como uma estrutura de divisão do trabalho; Preparar gráfico } \\
\text { de Gantt e usá-lo para acompanhar o progresso no projeto }\end{array}$ \\
\hline & & & $\begin{array}{l}\text { Medir e } \\
\text { monitorar o } \\
\text { desempenho e a } \\
\text { qualidade }\end{array}$ & $\begin{array}{l}\text { Comunicar minha expectativa de que as pessoas precisam } \\
\text { entender corretamente os detalhes de seu trabalho; Enfatizar a } \\
\text { necessidade de precisão nos esforços de trabalho; Enfatizar a } \\
\text { precisão nos esforços de trabalho; Identificar as melhores } \\
\text { medidas de desempenho baseadas em sua objetividade, } \\
\text { integridade, e responsividade; Distinguir entre medidas de } \\
\text { desempenho apropriadas e inapropriadas com respeito às metas } \\
\text { de uma unidade organizacional. }\end{array}$ \\
\hline & & & $\begin{array}{c}\text { Estimular e } \\
\text { possibilitar a } \\
\text { conformidade }\end{array}$ & $\begin{array}{l}\text { Ver que os procedimentos são entendidos; Certificar-se de que } \\
\text { as diretrizes formais estão claras para as pessoas; Assegurar que } \\
\text { políticas sejam conhecidas; Usar abordagens múltiplas para } \\
\text { encorajar a conformidade com as regras; Criar sistemas que } \\
\text { tornam mais fácil para os outros seguir procedimentos }\end{array}$ \\
\hline
\end{tabular}

Fonte: elaborada pelo autor (2018), com base em Quinn et al. (2015)

Competir está relacionado ao modelo de meta racional e visa efetivamente melhorar e aumentar a produtividade e a lucratividade. Para tanto, requer que todos entendam a missão da organização e o qual sua contribuição no alcance daquela. Os gestores que buscam esse imperativo de ação devem entender o ambiente externo por completo para em seguida transformar em realidade a visão da organização, comunicando não somente esta, mais também deixando claras as expectativas para os colaboradores por meio de planejamento e definição de metas, e projetando e organizando o trabalho. E, por fim, esses gestores devem 
transformar metas em ações que funcionem na prática. Dessa forma gestores competitivos devem ser éticos, ter a capacidade de executar ações rápidas e decisivas, além de serem orientados a tarefas e concentrados no trabalho. Genericamente, têm um perfil que se mostram altamente interessados, motivados, cheio de energia e estimulados, aceitam responsabilidades, executam tarefas e mantém alta produtividade pessoal. Como consequência dessas características os membros da equipe/unidade são incentivados a aumentar a produção e alcançar metas definidas (QUINN et al., 2015). As competências específicas são apresentadas no quadro 03.

Quadro 03 - competências associadas ao modelo de metas racionais

\begin{tabular}{|c|c|c|c|c|}
\hline Modelo & $\begin{array}{c}\text { Imperativo } \\
\text { de ação }\end{array}$ & Foco & Competências & Competências específicas \\
\hline \multirow{5}{*}{ 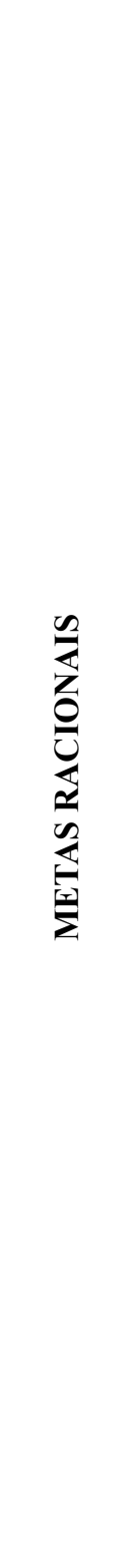 } & \multirow{5}{*}{ 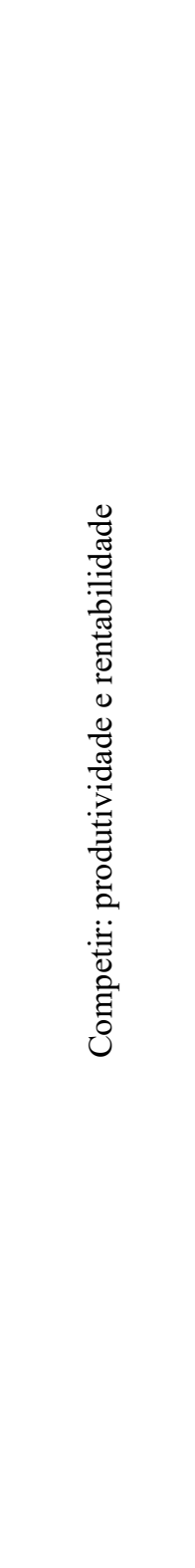 } & \multirow{5}{*}{ 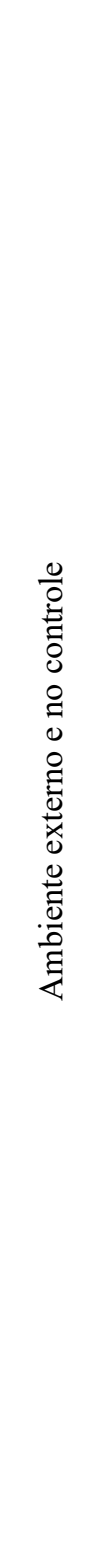 } & $\begin{array}{c}\text { Desenvolver e } \\
\text { comunicar uma } \\
\text { visão }\end{array}$ & $\begin{array}{l}\text { Enfatizar a necessidade de competir; Desenvolver um foco } \\
\text { competitivo; Insistir em vencer os concorrentes de fora; } \\
\text { Escrever uma visão que aborda a filosofia estratégica, } \\
\text { políticas e práticas táticas e emoções individuais; Contar } \\
\text { minha própria história de liderança para que as pessoas } \\
\text { entendam a paixão que me impulsiona e me sustenta }\end{array}$ \\
\hline & & & $\begin{array}{l}\text { Estabelecer } \\
\text { metas e } \\
\text { objetivos }\end{array}$ & $\begin{array}{l}\text { Identificar objetivos que não estão alinhados vertical ou } \\
\text { lateralmente na organização; Estabelecer metas e objetivos } \\
\text { que esclarecem as prioridades da unidade organizacional; } \\
\text { Avaliar um sistema de administração de desempenho para } \\
\text { ver se ele se relaciona apropriadamente aos objetivos de } \\
\text { desempenho organizacionais; Assegurar que metas são } \\
\text { desafiadoras, mas atingíveis, assim como relevantes para a } \\
\text { pessoa que tenta alcançar essas metas; Desenvolver metas } \\
\text { que são específicas, mensuráveis, e têm um prazo claro }\end{array}$ \\
\hline & & & $\begin{array}{l}\text { Motivar a si } \\
\text { mesmo e aos } \\
\quad \text { outros }\end{array}$ & $\begin{array}{l}\text { Mostrar um apetite por trabalho árduo; Modelar um intenso } \\
\text { esforço de trabalho; Demonstrar total empenho no trabalho; } \\
\text { Criar um ambiente de alto desempenho no qual os } \\
\text { funcionários podem se sentir capacitados e comprometidos; } \\
\text { Usar conhecimentos das teorias da motivação para } \\
\text { influenciar o comportamento dos outros }\end{array}$ \\
\hline & & & $\begin{array}{l}\text { Projetar e } \\
\text { organizar }\end{array}$ & $\begin{array}{l}\text { Melhorar desempenho ao aplicar apropriadamente os } \\
\text { conceitos de divisão do trabalho e especialização; Usar } \\
\text { diferentes ferramentas para criar integração através de uma } \\
\text { organização diferenciada; Diagnosticar a cultura } \\
\text { organizacional e determinar se a cultura existente está } \\
\text { alinhada com o ambiente competitivo; Distinguir entre } \\
\text { estruturas mecanicistas e organizacionais orgânicas; } \\
\text { Determinar se a departamentalização por função, divisão ou } \\
\text { matriz seria mais apropriada para uma determinada } \\
\text { organização }\end{array}$ \\
\hline & & & $\begin{array}{l}\text { Gerenciar a } \\
\text { execução e } \\
\text { buscar } \\
\text { resultados }\end{array}$ & $\begin{array}{l}\text { Fornecer respostas rápidas a questões emergentes; Enfatizar } \\
\text { a produção de resultados mais rápidos; Enfatizar que o } \\
\text { trabalho precisa ser feito mais rápido; Considerar as } \\
\text { questões humanas e de processo quando avaliando como } \\
\text { melhorar o desempenho; Administrar meu tempo para que } \\
\text { eu possa ter uma ideia precisa de quanto tempo estou } \\
\text { gastando em diferentes atividades }\end{array}$ \\
\hline
\end{tabular}

Fonte: elaborada pelo autor (2018), com base em Quinn et al. (2015) 
Criar representa os valores do modelo do sistema aberto e só alcança efetividade com base na capacidade de adaptação à mudança e aquisição de suporte externo. Consequentemente, como competência central os gestores devem facilitar a adaptação e a mudança, com particular relevância, está atento ao ambiente em transformação, identificar tendências cruciais e incentivar e orientar a inovação. Uma ressalva importante: para que os gestores possam colocar suas ideias em ação é necessária uma base sólida de poder e negociar acordos (QUINN et al., 2015). Apresenta-se o quadro 04 logo abaixo.

Quadro 04 - Competências associadas ao modelo de sistemas abertos

\begin{tabular}{|c|c|c|c|c|}
\hline Modelo & $\begin{array}{c}\text { Imperativo } \\
\text { de ação }\end{array}$ & Foco & Competências & Competências específicas \\
\hline \multirow{5}{*}{ 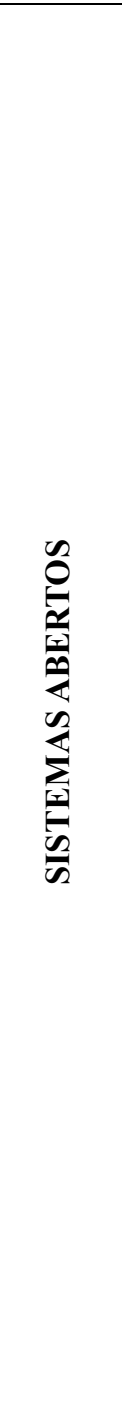 } & \multirow{5}{*}{ 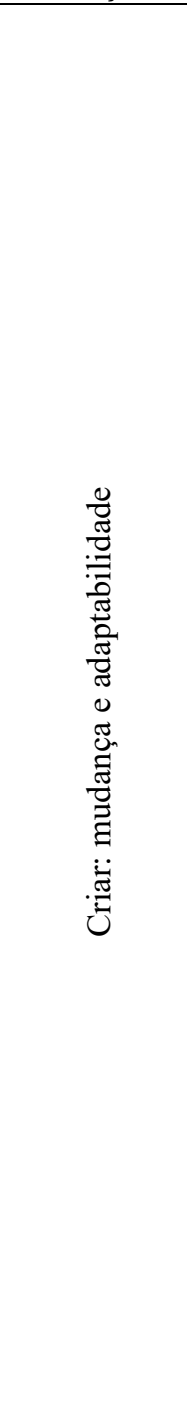 } & \multirow{5}{*}{ 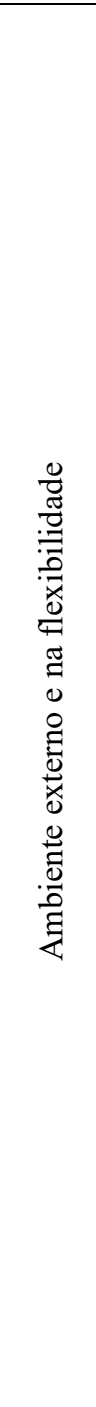 } & $\begin{array}{c}\text { Usar o poder e a } \\
\text { influência com } \\
\text { ética e } \\
\text { efetividade }\end{array}$ & $\begin{array}{l}\text { Reconhecer quando uma fonte de poder é sujeita a ser mais } \\
\text { útil do que outra fonte de poder; Construir poder pessoal } \\
\text { ao expandir minha rede pessoal; Usar diferentes táticas de } \\
\text { influência dependendo da situação; Aumentar meu poder } \\
\text { com constituintes específicos tais como meu supervisor, } \\
\text { colegas e subordinados; Entender como o poder pode ser } \\
\text { usado eficazmente }\end{array}$ \\
\hline & & & $\begin{array}{l}\text { Patrocinar e } \\
\text { vender novas } \\
\text { ideias }\end{array}$ & $\begin{array}{l}\text { Lançar novos esforços importantes; Iniciar projetos } \\
\text { ousados; Iniciar programas ambiciosos; Selecionar o estilo } \\
\text { de comunicação mais apropriado baseado no propósito de } \\
\text { minha mensagem; Antecipar contra-argumentos que outros } \\
\text { poderiam expressar quando eu faço uma recomendação }\end{array}$ \\
\hline & & & $\begin{array}{l}\text { Estimular e } \\
\text { promover } \\
\text { inovação }\end{array}$ & $\begin{array}{l}\text { Inspirar pessoas a serem criativas; Encorajar pessoas a } \\
\text { tentar novas coisas; Fazer as pessoas excederem os } \\
\text { padrões de desempenho tradicionais; Usar discussão e } \\
\text { técnicas de grupo nominais para promover o pensamento } \\
\text { inovador; Superar as barreiras individual e organizacional } \\
\text { ao pensamento criativo }\end{array}$ \\
\hline & & & $\begin{array}{c}\text { Negociar } \\
\text { acordos e } \\
\text { compromissos }\end{array}$ & $\begin{array}{l}\text { Identificar as necessidades mutáveis de clientes e outros } \\
\text { com quem eu negocio; Reunir-me com clientes e outros de } \\
\text { quem eu preciso obter um compromisso para discutir suas } \\
\text { necessidades; Antecipar o que os clientes e outros com } \\
\text { quem eu negocio quererá depois; Estabelecer propósito } \\
\text { mútuo, significado mútuo, e respeito mútuo quando } \\
\text { negociando com os outros; Focar em interesses, não } \\
\text { posições, quando eu negocio }\end{array}$ \\
\hline & & & $\begin{array}{c}\text { Implementar e } \\
\text { sustentar a } \\
\text { mudança }\end{array}$ & $\begin{array}{l}\text { Reduzir resistência à mudança; Determinar se uma } \\
\text { estratégia de mudança Participativa, Subjugadora, } \\
\text { Reveladora ou Transformacional seria a mais apropriada } \\
\text { em uma situação particular; Avaliar precisamente as forças } \\
\text { a favor e contra a mudança em uma determinada situação; } \\
\text { Reconhecer quando mudanças organizacionais propostas } \\
\text { são suscetíveis de provocar resistência do funcionário; } \\
\text { Planejar estratégias de mudança eficazes }\end{array}$ \\
\hline
\end{tabular}

Fonte: elaborada pelo autor (2018), com base em Quinn et al. (2015)

De forma geral é importante visualizar o modelo como um complexo estruturado de valores concorrentes e competências específicas para cada quadrante, para cada modelo de 
gestão (meta racional, processo interno, relações humanas e sistema aberto) e seus respectivos imperativos de ação gerencial (competição, controle, colaboração e criação).

Figura 04: Perfil de competência da abordagem de valores concorrentes

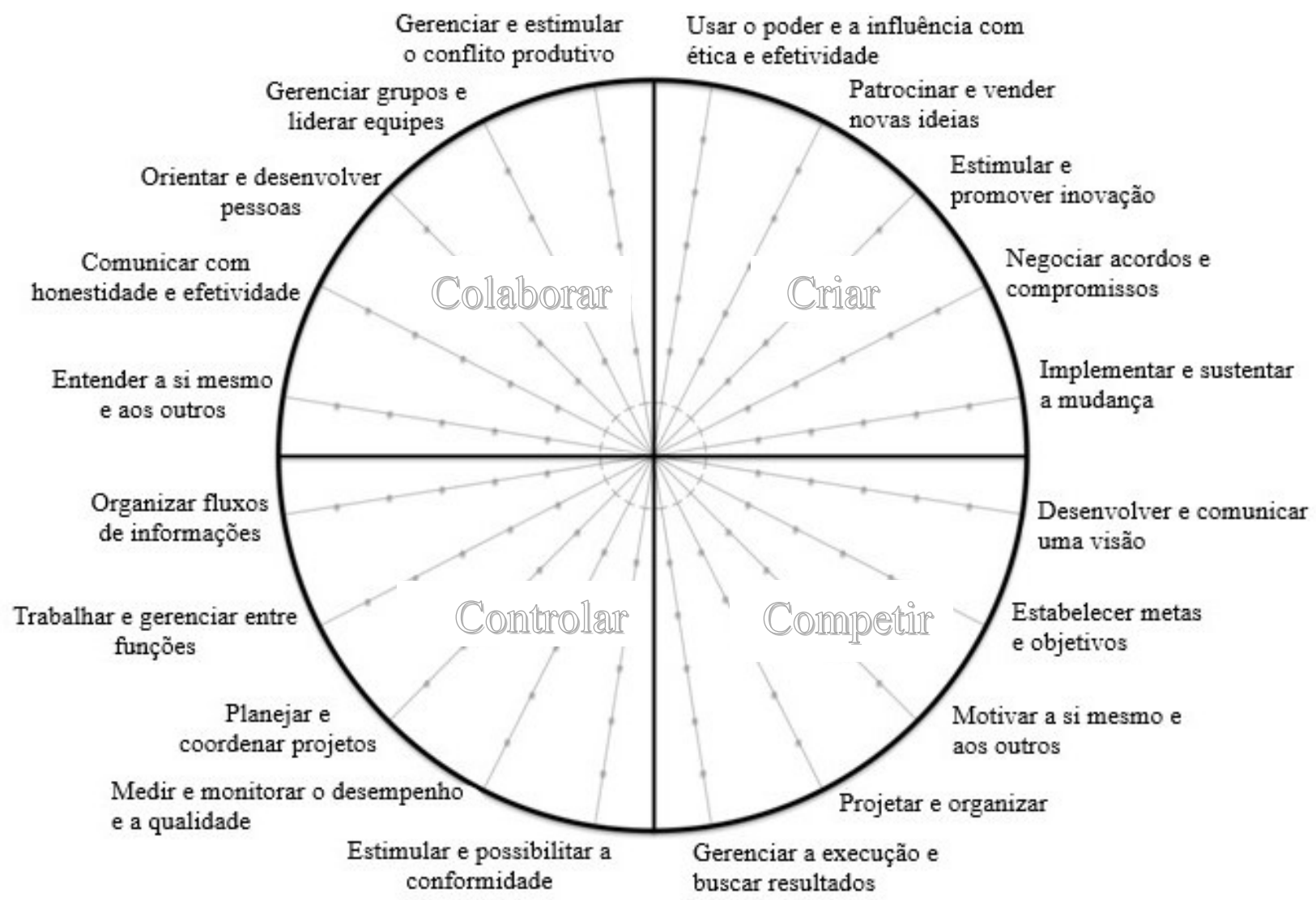

Fonte: Autor (2018), com base em Quinn et al. (2015)

A figura 04 nos mostra a ideia geral do modelo de Quinn et al. (2015) deixando evidente a complexidade com as quais os indivíduos irão se deparar nas organizações. $\mathrm{O}$ intuito é colocá-lo como um instrumento que amplie o pensamento e incremente as possibilidades de decisão e eficácia, o que, para Quinn et al. (2003), só é possível se o gestor desejar entender as vantagens e desvantagens de cada um dos quatro modelos, adquirir e colocar em prática as competências associadas a cada modelo e unificar de maneira dinâmica as competências de cada um dos modelos às situações gerenciais encontradas.

2.4.1 Cenários e sujeitos de estudos empíricos que utilizaram o modelo

$\mathrm{Na}$ seção anterior foram ressaltados todos os elementos que constituem a abordagem de valores concorrentes na gestão proposta por Quinn et al. (2015). Torna-se 
importante destacar que a teoria e o modelo proposto pelos autores, foi, inicialmente elaborada por Quinn (1988) e sofreram evoluções ao longo do tempo. No entanto, a ênfase na aceitação do paradoxo e o fato de que os gestores devem integrar as diferenças no contexto de suas atuações foram mantidos.

Determinadas as especificidades do modelo, segue-se com a caracterização dos estudos que utilizaram-se das propostas de Quinn e seus colaboradores. Nesse sentido, apresenta-se o Quadro 05 que demonstra genericamente as pesquisas encontradas na literatura brasileira e internacional, o contexto de aplicação dos estudos e os sujeitos pesquisados, representando, assim, um vasto e ampliado campo de aplicação das ideias dos autores e a ampla possibilidade de aplicação da abordagem de valores concorrentes na gestão.

Quadro 05: lócus e sujeitos estudados com base no modelo de Quinn e seus colaboradores

\begin{tabular}{|c|c|c|c|}
\hline Autor(es) & Objetivo & Metodologia & Resultados \\
\hline $\begin{array}{l}\text { Lima; Aragão; } \\
\text { Guimarães } \\
\text { (2016) }\end{array}$ & $\begin{array}{l}\text { Identificar as competências e } \\
\text { os papeis requeridos de } \\
\text { gerente de projetos que } \\
\text { atuam no setor da construção } \\
\text { civil }\end{array}$ & $\begin{array}{l}\text { Abordagem quantitativa/descritiva em } \\
\text { empresas de construção civil na região } \\
\text { metropolitana de Belo Horizonte - } \\
\text { MG; um survey com } 45 \text { gerentes de } \\
\text { projetos }\end{array}$ & $\begin{array}{l}\text { Demanda, sobretudo, competências } \\
\text { relacionadas aos papéis de Mentor, Produtor e } \\
\text { Diretor, predominando os modelos de metas } \\
\text { racionais e de relações humanas. }\end{array}$ \\
\hline $\begin{array}{l}\text { Lowen et al. } \\
\quad(2015)\end{array}$ & $\begin{array}{l}\text { Relacionar as competências } \\
\text { gerenciais requeridas dos } \\
\text { enfermeiros com o processo } \\
\text { de mudança vivenciado }\end{array}$ & $\begin{array}{l}\text { Estudo qualitativo, do tipo descritivo } \\
\text { e exploratório,realizado no programa } \\
\text { Estratégia Saúde da Família, em um } \\
\text { município do sul do Brasil; } 32 \\
\text { enfermeiros }\end{array}$ & $\begin{array}{l}\text { Competências gerenciais } \\
\text { implementar e sustentar mudanças, negociar } \\
\text { acordos e compromissos, usar o poder e } \\
\text { influenciar de forma etica e efetiva, } \\
\text { patrocinando e vendendo novas idéias e } \\
\text { incentivando e promovendo a inovação. }\end{array}$ \\
\hline $\begin{array}{l}\text { Pena et al. } \\
\text { (2015) }\end{array}$ & $\begin{array}{l}\text { Identificar as competências } \\
\text { que os líderes de turma } \\
\text { devem desenvolver para sua } \\
\text { atuação enquanto líderes no } \\
\text { contexto acadêmico e no } \\
\text { mercado de trabalho. }\end{array}$ & $\begin{array}{l}\text { Pesquisa qualitativa, exploratória, } \\
\text { descritiva em uma Organização de } \\
\text { ensino superior, grupos focais de } \\
\text { sujeitos estudantes de Administração, } \\
\text { líderes de turma e professores. }\end{array}$ & $\begin{array}{l}\text { Ocorrem contribuições do exercício da } \\
\text { liderança de turma para a formação do aluno, } \\
\text { principalmente, no que diz respeito ao } \\
\text { desenvolvimento das competências } \\
\text { comportamentais. Orientou-se a instituição } \\
\text { pesquisada observar a prática da liderança de } \\
\text { turma como uma oportunidade de desenvolver } \\
\text { os alunos, como líderes efetivos nos contextos } \\
\text { organizacionais. }\end{array}$ \\
\hline $\begin{array}{l}\text { Seabra; Paiva; } \\
\text { Luz (2015) }\end{array}$ & $\begin{array}{l}\text { Analisar como são } \\
\text { vivenciadas as competências } \\
\text { gerenciais, ideais e reais, de } \\
\text { coordenadores de cursos de } \\
\text { graduação }\end{array}$ & $\begin{array}{l}\text { Estudo descritivo qualitativo, com } 14 \\
\text { entrevistas feitas com roteiros semi- } \\
\text { estruturados, cujos dados foram } \\
\text { submetidos à análise de conteúdo }\end{array}$ & $\begin{array}{l}\text { Destacaram-se os papéis de mentor, diretor e } \\
\text { facilitador, cujas competências podem ser } \\
\text { aprimoradas continuamente em virtude das } \\
\text { demandas diferenciadas e permanentes a que } \\
\text { estão submetidos os sujeitos, além das } \\
\text { ambiguidades e contradições naturais da } \\
\text { função gerencial }\end{array}$ \\
\hline $\begin{array}{l}\text { Melo; Silva; } \\
\text { Parreira (2014) }\end{array}$ & $\begin{array}{l}\text { Identificar as percepções dos } \\
\text { enfermeiros liderados sobre o } \\
\text { desempenho dos papéis de } \\
\text { liderança pelo chefe de } \\
\text { enfermagem. }\end{array}$ & $\begin{array}{l}\text { Estudo descritivo e correlacional em } \\
\text { Instituições de saúde portuguesas, } \\
\text { com } 690 \text { enfermeiros }\end{array}$ & $\begin{array}{l}\text { Indicam que esses líderes são competentes. } \\
\text { Um mau desempenho do papel do facilitador } \\
\text { sugere a necessidade de os enfermeiros-chefe } \\
\text { adquirir habilidades de liderança que os } \\
\text { ajudem a gerenciar conflitos interpessoais e } \\
\text { promover a coesão e o trabalho em equipe. }\end{array}$ \\
\hline $\begin{array}{l}\text { Paiva; Santos; } \\
\text { Lacerda (2014) }\end{array}$ & $\begin{array}{l}\text { Analisar as competências } \\
\text { gerenciais e sua gestão no } \\
\text { setor hoteleiro }\end{array}$ & $\begin{array}{l}\text { Pesquisa de campo, descritiva, } \\
\text { abordagens quantitativa e qualitativa, } \\
\text { que contou com } 28 \text { gestores hoteleiros } \\
\text { de três estados brasileiros }\end{array}$ & $\begin{array}{l}\text { Percebeu-se a necessidade de harmonizar as } \\
\text { competências idealizadas e as efetivamente } \\
\text { vivenciadas; a gestão de suas competências } \\
\text { pauta-se em esforços do próprio sujeito, } \\
\text { contando também com o hotel onde trabalha } \\
\text { nesse sentido }\end{array}$ \\
\hline $\begin{array}{l}\text { Pinto et al. } \\
\text { (2014) }\end{array}$ & $\begin{array}{l}\text { Identificar as competências } \\
\text { gerenciais mais importantes } \\
\text { na percepção de gerentes }\end{array}$ & $\begin{array}{l}\text { Pesquisa descritiva em organização de } \\
\text { varejo atuante nos três estados da } \\
\text { região Sul do Brasil; com } 35 \text { gerentes }\end{array}$ & $\begin{array}{l}\text { Competências importantes aos gerentes: } \\
\text { estabelecimento de metas e objetivos, } \\
\text { desenvolvimento dos colaboradores e trabalho } \\
\text { produtivo }\end{array}$ \\
\hline
\end{tabular}

Continua... 


\begin{tabular}{|c|c|c|c|}
\hline Autor(es) & Objetivo & Metodologia & Resultados \\
\hline Seabra (2014) & $\begin{array}{l}\text { Analisar como se configuram } \\
\text { as competências gerenciais } \\
\text { de coordenadores de cursos } \\
\text { de graduação em } \\
\text { Enfermagem }\end{array}$ & $\begin{array}{l}\text { Estudo de caso e uma pesquisa de } \\
\text { campo, de caráter descritivo, com } \\
\text { abordagens qualitativa e quantitativa; } \\
\text { com } 14 \text { coordenadores de curso de } \\
\text { graduação em Enfermagem na cidade } \\
\text { de Belo Horizonte - MG. }\end{array}$ & $\begin{array}{l}\text { O perfil identificado para os coordenadores } \\
\text { pesquisados foi considerado eficaz e intitulado } \\
\text { de "agregadores pacíficos", o que demonstra } \\
\text { que as coordenadoras estão aptas a } \\
\text { desempenhar de forma competente os papéis } \\
\text { gerenciais considerando o equilíbrio entre } \\
\text { eles. }\end{array}$ \\
\hline $\begin{array}{l}\text { Paiva; Ferreira } \\
\text { (2013) }\end{array}$ & $\begin{array}{l}\text { Descrever as configurações } \\
\text { das competências gerenciais } \\
\text { de gestores da área de } \mathrm{TI} \text { em }\end{array}$ & $\begin{array}{l}\text { Pesquisa descritiva, com abordagem } \\
\text { quantitativa em organizações privadas } \\
\text { situadas no Triângulo Mineiro; com } \\
27 \text { gestores da área de TI }\end{array}$ & $\begin{array}{l}\text { Apontaram médias de performance real acima } \\
\text { do que eles consideram ser exigido pelas } \\
\text { empresas onde trabalham. }\end{array}$ \\
\hline $\begin{array}{l}\text { Barros et al. } \\
\quad(2013)\end{array}$ & $\begin{array}{l}\text { Identificar as competências } \\
\text { gerenciais desenvolvidas por } \\
\text { secretários executivos no } \\
\text { exercício da profissão }\end{array}$ & $\begin{array}{l}\text { Pesquisa quantitativa, levantamento } \\
\text { bibliográfico, com } 25 \text { profissionais } \\
\text { secretários executivos atuando como } \\
\text { gestor. }\end{array}$ & $\begin{array}{l}\text { As competências gerenciais são utilizadas, } \\
\text { contribuindo para o alcance de objetivos e } \\
\text { metas organizacionais, através da participação } \\
\text { no planejamento, na condução e estímulo às } \\
\text { pessoas e ao controle. }\end{array}$ \\
\hline $\begin{array}{l}\text { Nóbrega et al. } \\
\quad(2012)\end{array}$ & $\begin{array}{l}\text { Avaliar a percepção dos } \\
\text { nutricionistas gestores de } \\
\text { Unidades de Alimentação e } \\
\text { Nutrição Terceirizadas }\end{array}$ & $\begin{array}{l}\text { Pesquisa de campo, descritiva em } \\
\text { Unidades de Alimentação e Nutrição } \\
\text { terceirizadas de Natal/RN; } 12 \\
\text { Nutricionistas gestores }\end{array}$ & $\begin{array}{l}\text { Desenvolvem predominantemente suas } \\
\text { atividades voltadas ao desenvolvimento de um } \\
\text { ambiente de trabalho produtivo, tendo o foco } \\
\text { de seu trabalho para resultados, sendo pouco } \\
\text { requisitados os papéis gerenciais voltados para } \\
\text { a atividade de coordenação das equipes. }\end{array}$ \\
\hline Silva (2012) & $\begin{array}{l}\text { Identificar as competências } \\
\text { gerenciais dos gestores dos } \\
\text { hospitais públicos }\end{array}$ & $\begin{array}{l}\text { Pesquisa quanti-quali com } 13 \\
\text { diretores e } 30 \text { gerentes de } 15 \text { hospitais } \\
\text { públicos Hospitais da rede pública do } \\
\text { município de Belo Horizonte - MG. }\end{array}$ & $\begin{array}{l}\text { O estabelecimento de metas e objetivos, o } \\
\text { convívio com a mudança e a comunicação } \\
\text { eficaz foram as competências mais ressaltadas } \\
\text { pelos diretores; Já na concepção dos gerentes } \\
\text { as competências mais importantes foram a } \\
\text { negociação de acordos e compromisso, a } \\
\text { constituição e manutenção de uma base de } \\
\text { poder e a comunicação eficaz. }\end{array}$ \\
\hline Pires (2011) & $\begin{array}{l}\text { Compreender o elenco de } \\
\text { competências emergentes } \\
\text { requerido aos diretores da } \\
\text { Secretaria }\end{array}$ & $\begin{array}{l}\text { Pesquisa quali-quanti, descritiva, } \\
\text { explicativa com } 15 \text { diretores em cargo } \\
\text { de direção na Secretaria de Educação } \\
\text { da Bahia -Órgãos da Administração } \\
\text { Direta. }\end{array}$ & $\begin{array}{l}\text { Competências estão relacionadas aos papéis de } \\
\text { liderança os quais se sobressaíram o papel do } \\
\text { mentor (modelo das relações humanas) como } \\
\text { o de maior exigência e os papéis de inovador e } \\
\text { negociador como aqueles de menor frequêencia } \\
\text { de competências exigidas, cujo conjunto está } \\
\text { correlacionado aos valores competitivos da } \\
\text { inovação e adaptação e do crescimento e } \\
\text { aquisição de recurso. }\end{array}$ \\
\hline $\begin{array}{l}\text { Dias; Paiva } \\
\text { (2011) }\end{array}$ & $\begin{array}{l}\text { Analisar como se encontram } \\
\text { configuradas as competências } \\
\text { gerenciais, exigidas e } \\
\text { efetivas, dos enfermeiros }\end{array}$ & $\begin{array}{l}\text { Pesquisa de campo, descritiva, com } \\
\text { abordagem quantitativa com } 6 \\
\text { enfermeiros e } 4 \text { membros da equipe } \\
\text { de enfermagem em um Hospital da } \\
\text { rede privada em Belo Horizonte-MG }\end{array}$ & $\begin{array}{l}\text { Diferentes papéis e competências são exigidos } \\
\text { e efetivamente realizados pelos enfermeiros, } \\
\text { levando a questionamentos relativos às suas } \\
\text { competências gerenciais. }\end{array}$ \\
\hline $\begin{array}{l}\text { Dias; Paiva } \\
\text { (2009) }\end{array}$ & $\begin{array}{l}\text { Descrever e analisar como } \\
\text { variou a configuração das } \\
\text { competências profissionais e } \\
\text { gerenciais do estudante de } \\
\text { enfermagem, antes e depois } \\
\text { de cursarem duas disciplinas } \\
\text { de gestão }\end{array}$ & $\begin{array}{l}\text { Pesquisa de campo descritiva, } \\
\text { quantitativa com } 57 \text { estudantes do } \\
\text { curso de Enfermagem de uma } \\
\text { instituição privada em Belo } \\
\text { Horizonte-MG }\end{array}$ & $\begin{array}{l}\text { As disciplinas contribuíram para sua formação } \\
\text { em relação às competências gerenciais, } \\
\text { ampliando sua percepção a respeito das } \\
\text { competências envolvidas em todos os papéis } \\
\text { desempenhados, à exceção do papel de } \\
\text { mentor, cujos níveis de satisfação em termos } \\
\text { de atuação real não variaram e a média geral } \\
\text { variou muito pouco }\end{array}$ \\
\hline $\begin{array}{l}\text { Parumasur; } \\
\text { Govender } \\
\text { (2009) }\end{array}$ & $\begin{array}{l}\text { Avaliar em que medida o } \\
\text { gerenciamento em uma } \\
\text { divisão do setor público } \\
\text { exibe as funções e } \\
\text { competências descritas no } \\
\text { modelo }\end{array}$ & $\begin{array}{l}\text { Pesquisa quantitativa aplicada a } 202 \\
\text { gestores da Divisão do setor público } \\
\text { de uma província da África do Sul }\end{array}$ & $\begin{array}{l}\text { Imperativos necessários a realização de TQM: } \\
\text { necessidades e expectativas dos clientes; } \\
\text { Monitorando e controlando a qualidade } \\
\text { relacionada ao benchmarking competitivo; } \\
\text { Gestão participativa; equipes efetivas e } \\
\text { trabalho em equipe. }\end{array}$ \\
\hline Picchiai (2008) & $\begin{array}{l}\text { Descrever e comparar com o } \\
\text { modelo proposto, as } \\
\text { competências gerenciais dos } \\
\text { profissionais que ocupam } \\
\text { cargos de direção }\end{array}$ & $\begin{array}{l}\text { Estudo de caso, com análise } \\
\text { qualitativa e quantitativa dos dados e } \\
\text { informações. Organização hospitalar } \\
\text { pública de São Paulo; } 26 \text { ocupantes de } \\
\text { cargo de direção }\end{array}$ & $\begin{array}{l}\text { Preponderância do modelo de gestão de } \\
\text { recursos humanos e de sistemas abertos; Os } \\
\text { modelos de processos internos e de metas } \\
\text { racionais são menos percebidos e praticados } \\
\text { no todo }\end{array}$ \\
\hline Freitas (2007) & $\begin{array}{l}\text { Identificar, qual o nível de } \\
\text { desenvolvimento } \\
\text { competências e papéis do do } \\
\text { líder. }\end{array}$ & $\begin{array}{l}\text { Pesquisa quanti/quali; } 49 \text { gestores, } \\
\text { diretores e principais gerentes de uma } \\
\text { Organização multinacional francesa } \\
\text { do ramo de materiais de construção }\end{array}$ & $\begin{array}{l}14 \text { competências obtiveram o nível } \\
\text { desenvolvido e } 10 \text { competências atingiram o } \\
\text { nível pouco desenvolvido; necessário priorizar } \\
\text { o desenvolvimento dos líderes. }\end{array}$ \\
\hline Vilkinas (2000) & $\begin{array}{l}\text { Identificar oito funções } \\
\text { gerenciais que os gerentes } \\
\text { devem exibir se quiserem ser } \\
\text { eficazes }\end{array}$ & $\begin{array}{l}\text { Pesquisa quantitativa em organizações } \\
\text { diversas na Austrália; com uma } \\
\text { amostra de } 509 \text { gestores }\end{array}$ & $\begin{array}{l}\text { Não houve diferenças significativas na medida } \\
\text { em que os oito papéis foram exibidos nem o } \\
\text { nível de efetividade dos gerentes do sexo } \\
\text { masculino e feminino }\end{array}$ \\
\hline
\end{tabular}

Fonte: elaborado pelo autor (2018), com base nos dados de pesquisa 
Lima, Aragão e Guimarães (2016) buscaram entender quais seriam as competências e os papeis demandados de gerentes de projetos do ramo da construção civil, para tanto realizaram uma pesquisa do tipo survey junto a 45 gerentes, em 27 empresas de grande porte da região metropolitana de Belo Horizonte - MG, e chegaram a conclusão que o modelo de relações humanas e metas racionais são predominantes, haja vista que as competências requeridas e com maior nível de domínio dos gestores pesquisados são relacionadas aos papeis de mentor, produtor e diretor, são elas: convívio com as mudanças, administração de conflitos, comunicação eficaz, análise de informações com pensamento crítico, trabalho produtivo, compreensão de si mesmo e dos outros.

Lowen et al. (2015) entrevistaram 32 enfermeiros com o intuito de analisarem o processo de ampliação da Estratégia Saúde da Família, em um município do sul do Brasil, e relacioná-lo às competências gerenciais dos sujeitos para implementar as mudanças necessárias e no processo de análise qualitativa descobriram que o processo de ampliação da Estratégia Saúde da Família, os enfrentamentos e as potencialidades, a mobilização para a mudança e a inovação na consulta médica e na do enfermeiro foram questões dominantes nesse processo de mudança e para que isso acontecesse seria necessário competências gerenciais de implementar e sustentar a mudança, negociar acordos e compromissos, usar o poder e a influência com ética e efetividade, patrocinar e vender novas ideias e estimular e promover inovação.

O diferencial nesse estudo é que os autores focaram no Modelo de Sistema Aberto, associado ao imperativo Criar, o qual, conforme Quinn et al. (2015) busca promover a mudança e estimular a adaptabilidade através de suas 5 competências, conforme demonstrado em seção anterior.

Pena et al. (2015) inferiram, através de grupos focais em uma instituição de ensino superior, que o exercício de liderança de turma influencia no desenvolvimento de competências comportamentais e identificaram que as competências advindas dos papeis gerenciais propostos por Quinn et al. (2003), são essenciais à atuação dos líderes de turma no contexto acadêmico.

Seabra, Paiva e Luz (2015), analisaram através de entrevistas como são vivenciadas as competências gerenciais, ideais e reais, de coordenadores de cursos de graduação em Enfermagem na cidade de Belo Horizonte - MG, destacaram-se a partir da pesquisa os papéis de mentor, diretor e facilitador, cujas competências podem ser aprimoradas, além das ambiguidades e contradições naturais da função gerencial. Nesse sentido as autoras concluem que as instituições de ensino superior podem ajustar seus 
processos seletivos e avaliativos para tal cargo, compreendendo as dificuldades de formação das competências profissionais exigidas no exercício da função gerencial.

É importante inferir e citar do referido estudo a importância e o nível de aderência do framework de Quinn et al. (2015) ao contexto pesquisado, pois o arcabouço teórico com seus modelos e competências abrangeram com propriedade a gestão de projetos na construção civil, conforme sinalizado pelos autores da pesquisa, revelando assim o nível de amplitude do modelo.

Paiva, Santos e Lacerda (2014) analisaram a configuração e como são geridas as competências gerenciais (ideais e reais) no setor hoteleiro, com base em pesquisa quantitativa e qualitativa com 28 gestores hoteleiros, situados nos estados de São Paulo, Minas Gerais e Rio de Janeiro, e perceberam a partir dos resultados a necessidade de harmonizar as competências idealizadas (voltadas aos papeis de mentor e coordenador) e as efetivamente vivenciadas (direcionadas para os papeis de mentor e produtor) pelos gestores brasileiros pesquisados, dadas as diferenças observadas. Além disso, a gestão de suas competências pauta-se em esforços do próprio sujeito, contando também com o hotel onde trabalha nesse sentido.

Pinto et al. (2014) através de uma pesquisa descritiva identificaram que as competências gerenciais mais importantes na percepção de 35 gerentes de uma organização de varejo atuante nos estados do Rio Grande do Sul, Santa Catarina e Paraná são: o estabelecimento de metas e objetivos, o desenvolvimento dos colaboradores e trabalho produtivo. Os sujeitos apontaram, em média, que não possuem totalmente as competências presentadas pelo modelo, identificou-se ainda que a experiência profissional e pessoal do gerente dentro da organização é o principal fator que contribui para a aquisição de competências.

Melo, Silva e Parreira (2014) ao realizarem um estudo descritivo e correlacional, com o intuito de compreender a percepção dos enfermeiros sobre os papéis de liderança desempenhados pelos enfermeiros gestores, descobriram a partir de uma amostra composta por 690 enfermeiros, que as percepções dos enfermeiros subordinados ficaram acima do ponto médio da escala em todos os papeis de liderança propostos no modelo, deixando evidente que esses líderes são competentes, no entanto, os resultados mostraram um mau desempenho no papel de facilitador, exigindo, dessa forma a necessidade de adquirir habilidades de liderança que os ajudem a gerenciar conflitos interpessoais e promover coesão e trabalho em equipe.

Seabra (2014) analisou a configuração das competências gerenciais de coordenadores de cursos de graduação em Enfermagem na cidade de Belo Horizonte e 
concluiu que os sujeitos pesquisados são "agregadores pacíficos", pois conforme o modelo teórico adotado de Quinn et al. (2003) os coordenadores estão aptos a desempenharem os papeis gerenciais considerando o equilíbrio entre eles, com destaque para os papeis de mentor, diretor, coordenador e facilitador, isso seria o ideal na perspectiva dos sujeitos da pesquisa, porém, quanto ao que conseguem realmente executar os sujeitos atribuíram valores medianos aos papeis de negociador e de monitor, demonstrando claramente que o ideal não é compatível com o real, além disso o papel de negociador alcançou o menor desempenho entre os sujeitos.

Paiva e Ferreira (2013) buscaram descrever as configurações das competências gerenciais de gestores da área de TI, em organizações situadas no Triângulo Mineiro, e concluíram que, na visão dos sujeitos pesquisados, as competências gerenciais ideais estariam fortemente relacionadas aos papeis de monitor e inovador e o modelo de metas racionais seria o menos indicado para função na percepção dos gestores pesquisados. No entanto quando se quis saber sobre as competências gerenciais efetivamente colocadas em prática, os gestores pesquisados demonstraram percentuais elevados para todos os oito papeis gerenciais, conforme modelo teórico de Quinn et al. (2003), com destaque positivo para o papel de produtor e menos representativo para o de monitor. Nesse sentido é importante ressaltar que os autores da pesquisa encontraram que os sujeitos pesquisados apontaram médias de performance real acima do que eles consideram ser exigido pelas organizações onde atuam.

Barros et al. (2013), a partir de um estudo quantitativo descritivo aplicado, tomando-se como sujeitos 25 (vinte e cinco) profissionais da área de secretariado executivo (ou em formação) que desenvolvessem atividades gerenciais, identificaram que esses sujeitos utilizam, principalmente as seguintes competências gerenciais: compreensão de si mesmo e dos outros, comunicação eficaz, construção de equipes, administração de informações por meio de pensamento crítico e coordenação de projetos e/ou eventos. Os autores consideram, a partir das conclusões da pesquisa, que o profissional Secretário Executivo utiliza as competências gerenciais abordadas pelo modelo de Quinn et al. (2003) no cotidiano de suas atividades e que aqueles contribuem para o desenvolvimento organizacional.

Nóbrega et al. (2012) realizaram sua pesquisa no âmbito de Unidades de Alimentação e Nutrição terceirizadas de Natal/RN, avaliando a percepção dos Nutricionistas gestores dessas unidades sobre suas competências gerenciais e chegaram a conclusão que dentre as competências efetivas destacadas pelos sujeitos estudados a que obteve maior média foi a necessidade de se estimular o desenvolvimento de um ambiente produtivo, sendo orientado para a tarefa, destacando-se o papel de produtor, já o papel de coordenador foi o 
menos presente. Os autores concluíram ainda que o perfil dos sujeitos aponta para o modelo de metas racionais e que essa percepção dos Nutricionistas gestores se aproxima do perfil denominado "Adaptativos Caóticos", gerencialmente sem eficácia, conforme aponta o modelo de Quinn et al. (2003).

Silva (2012) buscou identificar as competências gerenciais dos gestores que atuam em hospitais da rede pública do município de Belo Horizonte - MG, através de uma pesquisa descritiva e exploratória, a partir de análise quantitativa e qualitativa. Destacando-se, inicialmente, que os gestores sujeitos da pesquisa realizaram cursos formais de capacitação antes e durante suas atividades, o que não necessariamente leva a ação efetiva. O autor chegou a conclusão que o papel de diretor é predominante na visão dos gestores hospitalares, com destaque para os papeis de negociador e coordenador e para as competências "estabelecimento de metas e objetivos" e "planejamento e organização". Houve ainda discrepância entre a percepção e valorização dos diretores e dos gerentes quanto aos papéis gerenciais de facilitador e negociador. É importante ressaltar que o autor enfatiza que o modelo de Quinn et al. (2003) foi adequado ao contexto das organizações públicas, no entanto, chegou a conclusão no estudo que é necessário incluir o "papel político" no modelo para que ele fique mais completo e voltado a realidade dos hospitais públicos.

Pires (2011) desenvolveu seu estudo junto aos diretores da Secretaria de Educação da Bahia - Órgãos da Administração Direta, com o intuito de compreender as competências emergentes e os papéis de liderança requeridos e relacionar essas competências aos modelos de gestão vigentes. E concluiu que a secretaria estudada é caracterizada essencialmente como pertencente ao modelo dos processos internos, visto a freqüência das competências sociais exigidas aos seus diretores administrativos e cujos valores competitivos estão focados na estabilidade e controle e no ambiente interno. Dentre essas competências relacionadas aos papéis de liderança, o papel do mentor (modelo das relações humanas) foi relacionado como o de maior exigência e os papéis de inovador e negociador como aqueles de menor freqüência de competências exigidas. Assim, a autora conclui que a secretaria, apesar do equilíbrio representado para cada um dos modelos de gestão apresentado por Quinn et al. (2003) falta ainda um alinhamento tanto do entendimento, melhor aproveitamento das vantagens existentes, avaliação e foco de esforços voltados para o desenvolvimento das competências individuais.

Dias e Paiva (2011) analisaram qualitativamente a configuração das competências gerenciais, exigidas e efetivas, dos enfermeiros de um hospital da rede privada em Belo Horizonte - MG, na percepção dos enfermeiros e de outras categorias da Enfermagem e 
observaram que diferentes papéis e competências são exigidos e efetivamente realizados pelos enfermeiros, principalmente nos papéis de monitor, mentor e facilitador. Levando-se a questionamentos relativos às suas competências gerenciais.

Parumasur e Govender (2009) avaliaram até que ponto a gestão em uma divisão do setor público de uma província da África do Sul exibe os papéis e competências descritos no modelo de Quinn et al. (2003). O estudo foi realizado a partir de uma amostra aleatória estratificada de 202 gestores. Os dados foram coletados utilizando-se um questionário autodesenvolvido que mede as dimensões da gestão da qualidade total e os papéis/competências necessários para criar gerentes eficazes, cruciais para o aprimoramento da TQM e chegarma a conclusão que é necessário implementar estratégias e recomendações para reforçar os papéis gerenciais, criando assim mestres gerentes que serão equipados para atingir as dimensões que contribuem para TQM (foco nas necessidades e expectativas dos clientes, monitoramento e controle da qualidade, gestão participativa, equipes e trabalho em equipe e suporte contínuo da alta administração, treinamento e aprendizado) e acelerando a sua realização. Ressalta-se nesse estudo a relação estatistica que foi realizada com outra escala, a quantidade de sujeitos pesquisados e a aplicação no setor público.

Dias e Paiva (2009) descreveram e analisaram como variou a configuração das competências profissionais e gerenciais do estudante de enfermagem, antes e depois de cursarem duas disciplinas de gestão no curso de enfermagem de uma instituição de ensino superior (IES) privada, em Belo Horizonte - MG, e concluíram que do ponto de vista do "ideal", os sujeitos demonstraram que tais disciplinas contribuíram para sua formação, no entanto quanto aos papeis de mentor, coordenador e diretor não houve alteração em suas percepções.

Os autores do estudo relatado afirmaram que escolheram o modelo de Quinn et al. (2003) por este retratar melhor a realidade vivenciada pelos lidere de turma, demonstrando dessa forma outro contexto em que o framework se encaixou e foi usado como referência em pesquisas acadêmicas.

Picchiai (2008) descreveu como os profissionais que ocupam cargos de direção (diretores, gerentes e chefias) em uma organização hospitalar percebem as competências gerenciais e comparou estas descrições obtidas com as desenhadas no modelo de competências gerenciais proposto por Quinn et al. (2003). Através desse estudo de caso o autor conclui que o modelo de relações humanas e de sistema aberto foram os mais preponderantes, já os modelos de processos interno e metas racionais corresponderam ao de menor ênfase, segundo dados dos respondentes; já os papeis mais valorizados foram os de 
inovador e mentor, e os papéis de coordenador, monitor e negociador foram menos praticados e percebidos, o que pode ser explicado pela estrutura da organização, por sua cultura, por seus valores e pela lógica de suas atividades

Freitas (2007) através de um estudo de caso na sede de uma organização multinacional francesa do ramo de materiais de construção, utilizando-se de questionários e entrevistas, identificou o nível de desenvolvimento das competências e papéis do líder, chegando a conclusão de que 14 competências obtiveram o nível desenvolvido e 10 competências atingiram o nível pouco desenvolvido; seis papéis obtiveram o resultado de "desenvolvidos" (inovador, negociador, produtor, diretor, monitor e mentor) e dois papéis foram considerados "pouco desenvolvidos" (facilitador, coordenador), conforme modelo de Quinn et al. (2003). A partir desses dados, o autor inferiu onde é necessário priorizar o desenvolvimento dos líderes, visando a melhoria das competências e consequentemente do resultado dos negócios da organização.

Vilkinas (2000) em um estudo com 509 gestores, 127 dos quais eram do sexo feminino, responderam a uma pesquisa explorando o grau em que exibiam cada um dos papéis gerenciais de adotado no modelo de Quinn et al. (2003) Cada funcionário dos gestores foi solicitado a responder ao questionário. Quando se tomou em consideração o gênero dos gestores e dos seus outros significativos (pessoal, pares e chefe), não se registrou qualquer diferença significativa na medida em que os oito papeis foram exibidos nem no nível de eficácia dos gestores homens e mulheres. Os resultados deste estudo indicam que o gênero do gerente não tem impacto sobre como eles são percebidos pelos seus outros significativos. Em vez disso, é o quão eficaz eles são como gerentes que determinam as percepções dos outros.

A literatura pesquisada não apresenta considerações sobre competências gerenciais no âmbito dos Institutos Federais de Educação (IF's), porém há estudos consideráveis sobre o setor público, de um modo geral, e em especial em universidades federais. Do ponto de vista teórico, de pesquisa, não há estudos científicos suficientes voltados a examinar o gestor público no contexto de instituições públicas de ensino como os Institutos Federais de Educação, no entanto é perceptível, como afirma Esther (2011), um grande interesse sobre a gestão universitária em geral. Os Institutos Federais de Educação são equiparados às universidades federais (BRASIL, 2008), porém, tem todo um contexto de finalidades e objetivos particulares dessas instituições que não condizem com a realidade organizacional e administrativa das universidades federais brasileiras. Nesse sentido, segue a descrição da proposta metodológica do estudo. 


\section{ASPECTOS METODOLÓGICOS}

No intuito de descrever o enquadramento metodológico do estudo e buscar o alcance dos objetivos geral e específicos delimitados para a pesquisa, nesta seção apresentarse-á uma descrição do caminho metodológico adotado no que se refere à tipologia de pesquisa (natureza, meios e fins), o universo objeto de estudo, os métodos de coleta e análise de dados.

\subsection{Tipologia da pesquisa}

Conforme o objetivo proposto, a presente pesquisa possui natureza essencialmente descritiva, pois visa investigar as características da configuração do perfil de competências gerenciais nos Institutos Federais de Educação brasileiros. Dessa forma, o intuito é especificar as propriedades, as características e os perfis importantes dos sujeitos, objetos da análise (SAMPIERI; COLLADO; LUCIO, 2013), podendo assim, classificá-la como descritiva, já que tem esse intuito de descrever o comportamento do objeto de estudo em questão (COLLIS; HUSSEY, 2005). Portanto, o planejamento da pesquisa foi estruturado e criado para medir as características descritas no problema de pesquisa e fornecer um panorama dos elementos em um dado ponto no tempo, delimitando-se, dessa forma como um estudo descritivo transversal (HAIR Jr. et al., 2005). A pesquisa do tipo survey descritivo foi usada nesse estudo, pois ela permite descobrir a distribuição de certos traços e atributos da população em estudo (BABIE, 2005).

Quanto à forma de abordagem do problema, essa pesquisa classifica-se como quantitativa. Para Creswell (2010) o cenário da abordagem de pesquisa quantitativa tipicamente usa declarações de conhecimento pós-positivista, emprega estratégia de investigação de levantamento, usa métodos com questões fechadas, abordagens predeterminadas e dados numéricos, onde o pesquisador testa ou verifica teorias ou explicações, observa e avalia as informações numericamente, empregando procedimentos estatísticos.

A abordagem da pesquisa adotou como padrão teórico o modelo de Quinn et al. (2015), que enfatiza a inserção e uma nítida relação conflitante de quatro modelos (meta racional, relações humanas, sistema aberto e modelo de processo interno) que são a base para a discussão de diferentes competências centrais necessárias para uma gestão efetiva, surgindo esse modelo de gerenciamento integrado chamado estrutura de valores concorrentes.

A seguir será apresentado com maior profundidade o objeto de estudo em questão, os respondentes, suas características e definições que servirão de base para a pesquisa. 


\subsection{População e amostra da pesquisa}

O universo populacional da pesquisa é constituído pelos Institutos Federais de Educação, Ciência e Tecnologia (Institutos Federais - If's), tendo como respondentes diretos os ocupantes do cargo de Direção Geral de todos os campi dos Institutos Federais de Educação espalhados pelo Brasil. Portanto, o elemento populacional, a unidade de estudo, é o ocupante da função de Direção Geral dos campi de todos os Institutos Federais, pois conforme Coooper e Schindler (2011) o elemento da população é a pessoa que está sendo considerada para mensuração.

Nesse sentido o campus na configuração organizacional dos institutos federais e os seus respectivos diretores gerais de campi são importantes para o alcance dos objetivos de cada unidade da federação na medida em que detêm o poder de tomar decisões que implique em consecução ou não dos objetivos organizacionais, pois eles compõem o Colégio de Dirigentes que, juntamente com o Conselho Superior, integram os órgãos máximos da administração dos Institutos Federais, conforme detalhado na seção posterior (BRASIL, 2008).

A população é o conjunto completo de elementos sobre os quais se faz algumas inferências, já o censo é a contagem de todos os elementos em uma população (COOPER; SCHINDLER,2011). Portanto, essa pesquisa atende toda a população, pois serão considerados todos os 38 (trinta e oito) Institutos Federais e todos os 602 (seiscentos e dois) campi e respectivos Diretores Gerais, conforme tabela 01.

Tabela 01: Quantidade de IF's e Campi por Unidade da Federação

\begin{tabular}{rcc}
\hline UF & Institutos Federais & Campi \\
\hline Acre & 1 & 6 \\
Alagoas & 1 & 16 \\
Amapá & 1 & 5 \\
Amazonas & 1 & 15 \\
Bahia & 2 & 23 \\
Ceará & 1 & 31 \\
Distrito Federal & 1 & 11 \\
Espírito Santo & 1 & 22 \\
Goiás & 2 & 14 \\
Mato Grosso & 1 & 19 \\
Maranhão & 1 & 28 \\
Mato Grosso do Sul & 1 & 10 \\
\hline
\end{tabular}




\begin{tabular}{rcc}
\hline Minas Gerais & 5 & 18 \\
Pará & 1 & 18 \\
Paraíba & 1 & 18 \\
Paraná & 1 & 25 \\
\hline Pernambuco & 2 & 15 \\
Piaú & 1 & 20 \\
\hline Rio de Janeiro & 2 & 12 \\
\hline Rio Grande do Norte & 1 & 20 \\
\hline Rio Grande do Sul & 3 & 17 \\
\hline Rondônia & 1 & 9 \\
\hline Roraima & 1 & 5 \\
São Paulo & 1 & 38 \\
\hline Santa Catarina & 2 & 22 \\
Sergipe & 1 & 9 \\
\hline Tocantins & 1 & 11 \\
\hline Total & $\mathbf{3 8}$ & $\mathbf{6 0 2}$ \\
\hline
\end{tabular}

Fonte: elaborada pelo autor (2018), com base em pesquisa documental

No entanto, como a população a ser estudada abrange 602 diretores gerais de campi, relativamente expressiva, embora finita, torna-se indispensável selecionar uma amostra representativa. Nesse sentido, de acordo com a formulação do problema, com a hipótese apresentada, com o desenho da pesquisa, optou-se por uma amostragem probabilística, caracterizada como um subgrupo da população em que todos os elementos desta têm a mesma possibilidade de ser escolhidos e que proporciona reduzir o erro amostral ao mínimo e maximizar o nível de confiança (SAMPIERI; COLLADO; LUCIO, 2013).

Dessa forma, o tamanho amostral selecionado foi determinado usando o fator de correção para população finita proposto por Triola (2013), conforme expressão a seguir:

$$
n=\frac{N p q\left[z_{\alpha / 2}\right]^{2}}{p q\left[z_{\alpha / 2}\right]^{2}+(N-1) E^{2}}
$$

Sendo que: $n$ : tamanho da amostra; $N$ : tamanho da população; $p$ : proporção amostral; $q: 1-p ; z_{\alpha / 2}$ : valor crítico; $E$ : margem de erro $\left(\mathrm{E}=z_{\alpha / 2} p q / n\right)$.

$\mathrm{O}$ valor crítico $\left(z_{\alpha / 2}\right)$ na fórmula acima descrita é um número de fronteira que separa estatísticas amostrais que têm chance de ocorrer daquelas que não têm; a margem de erro, representada por $E$, é a diferença máxima provável (com probabilidade $1-\alpha$, tal como $0,95)$ entre a proporção amostral observada e o verdadeiro valor da proporção populacional (TRIOLA, 2013). 
Para Triola (2013) um intervalo de confiança é uma faixa ou um intervalo de valores usada para se estimar o verdadeiro valor de um parâmetro populacional; já o nível de confiança é a probabilidade $1-\alpha$ (em geral expressa em porcentagem - 90\%, 95\% e 99\%) de que o intervalo de confiança realmente contenha o parâmetro populacional. Portanto, $\alpha$ é o complementar do nível de confiança. Para um nível de confiança de 0,90 (ou 90\%), $\alpha=0,10$. Para um nível de confiança de 0,95 (ou 95\%), $\alpha=0,05$. E para um nível de confiança de 0,99 (ou $99 \%$ ), $\alpha=0,01$.

Conforme expressão adotada e características da pesquisa, segue a tabela 02 , na qual consta os tamanhos das amostras conforme nível de confiança, margem de erro e valores críticos.

Tabela 02 - Tamanho da amostra para a população da pesquisa

\begin{tabular}{c|c|c|c}
\hline Nível de confiança & $\boldsymbol{\alpha}$ & Valor crítico, $z_{\alpha / 2}$ & $\boldsymbol{n}$ \\
\hline $90 \%$ & 0,10 & 1,645 & 58 \\
$95 \%$ & 0,05 & 1,96 & 229 \\
$99 \%$ & 0,01 & 2,575 & 580 \\
\hline
\end{tabular}

Fonte: elaborada pelo autor (2018)

Partindo desses resultados e de pesquisas que fundamentaram o presente estudo, adotou-se como tamanho da amostra $n=229$, considerando um nível de confiança de $95 \%$ e erro máximo aceitável de $5 \%, \alpha=0,05$. A escolha é justificada por ser a abordagem mais conservadora e mais rígida, na visão de Sampierri, Collado e Lucio (2013) e por não encontrar na literatura estudos anteriores que apontassem o valor proporcional aplicável ao fenômeno das competências gerenciais no âmbito dos institutos federais de educação.

\subsubsection{Os Institutos Federais}

Os Institutos Federais são autarquias e, conforme propõe a Lei n ${ }^{0}$ 11.892/2008, têm a missão de articular a educação superior, básica e profissional nas mais diversas áreas, com foco especial na oferta de educação profissional e tecnológica nas diferentes modalidades de ensino. Administrativamente são autônomos, possuem suas regras, gerenciam seu patrimônio, decidem sobre suas finanças e sobre sua postura didático-pedagógica e disciplinar, funcionando através de multicampi espalhados pelos territórios onde atuam (BRASIL, 2008).

O Institutos Federais de Educação fazem parte da Rede Federal de Educação Profissional, Científica e Tecnológica, instituída no âmbito do sistema federal de ensino, 
vinculada ao Ministério da Educação e constituída pelos Institutos Federais de Educação, Ciência e Tecnologia (Institutos Federais), pela Universidade Tecnológica Federal do Paraná (UTFPR), pelos Centros Federais de Educação Tecnológica Celso Suckow da Fonseca (CEFET-RJ) e de Minas Gerais (CEFET-MG), pelas Escolas Técnicas Vinculadas às Universidades Federais e pelo Colégio Pedro II (BRASIL, 2008).

Observa-se pela tabela 01 que a estrutura multicampi dos Institutos Federais favorece ao alcance de suas finalidades e objetivos para os quais foram criados, além disso a descentralização das ações administrativas ficam mais evidentes, já que a administração dos Institutos Federais é exercida pelo Colégio de Dirigentes e pelo Conselho Superior, nota-se a figura 05 que demonstra a estrutura organizacional dos IF's.

Figura 05: estrutura organizacional genérica dos Institutos Federais

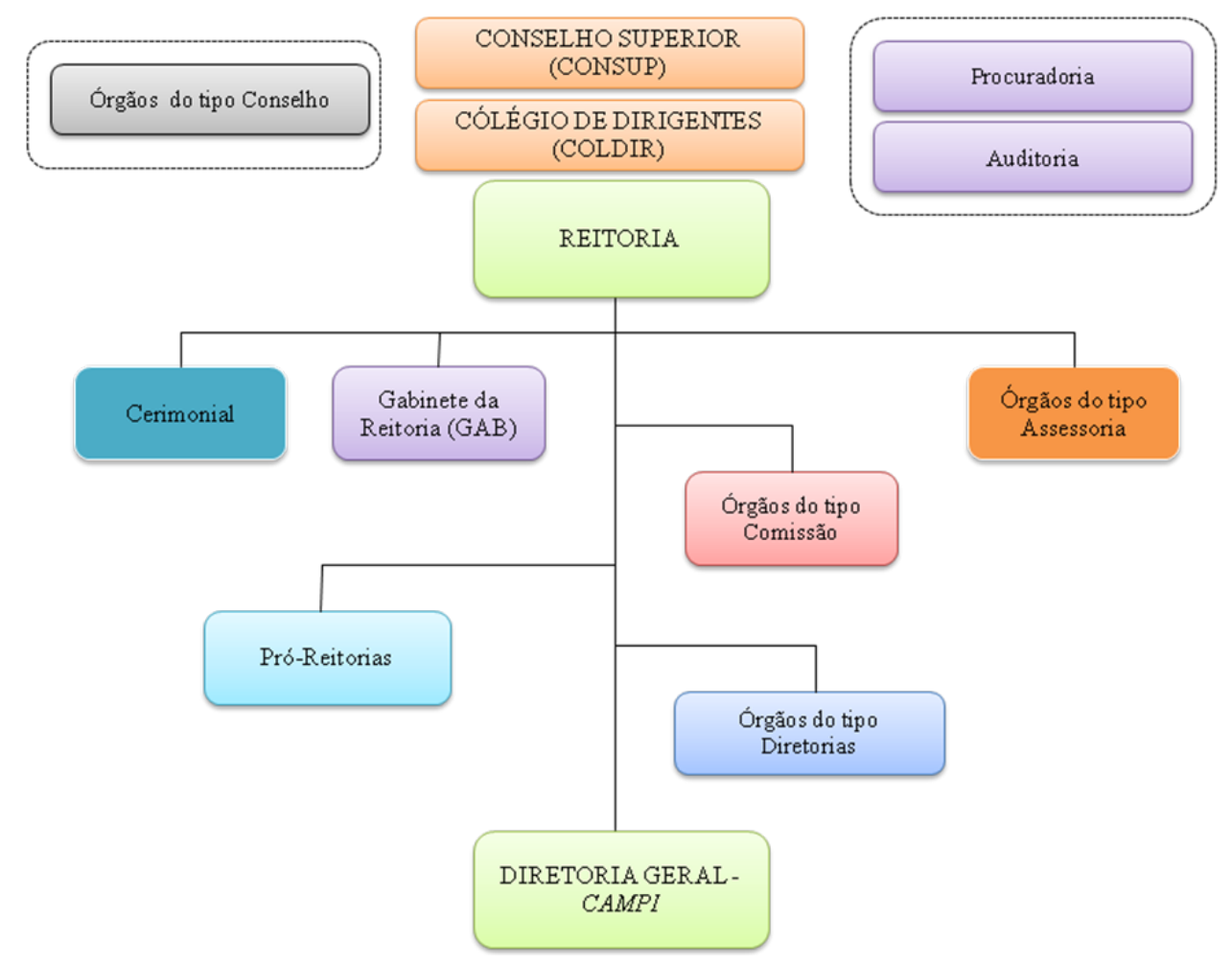

Fonte: elaborada pelo autor (2018), com base em pesquisas documentais

Conforme aponta a Lei 11.892/2008 as presidências do Colégio de Dirigentes e do Conselho Superior serão exercidas pelo Reitor do Instituto Federal, sendo que o Colégio de Dirigentes (órgão de caráter consultivo) será composto pelo Reitor, pelos Pró-Reitores e pelo Diretor-Geral de cada um dos campi. Já o Conselho Superior, também de caráter consultivo, porém deliberativo, será composto por representantes dos docentes, dos estudantes, dos servidores técnico-administrativos, dos egressos da instituição, da sociedade civil, do Ministério da Educação e do Colégio de Dirigentes, assegurando-se a representação paritária 
dos segmentos que compõem a comunidade acadêmica (BRASIL, 2008).

Conforme exposto na Figura 01 os Institutos Federais terão como órgão executivo a reitoria, composta por 1 (um) Reitor e 5 (cinco) Pró-Reitores e as Direções gerais de campi, composta pelos respectivos diretores gerais, nomeados pelo Reitor para mandato de 4 (quatro) anos, permitida uma recondução, após processo de consulta à comunidade do respectivo campus (BRASIL, 2008). Para a Lei 11.892/2008 só pode assumir essa função de Direção Geral de campus os servidores ocupantes de cargo efetivo da carreira docente ou de cargo efetivo de nível superior da carreira dos técnico-administrativos do Plano de Carreira dos Cargos Técnico-Administrativos em Educação, desde que possuam o mínimo de 5 (cinco) anos de efetivo exercício em instituição federal de educação profissional e tecnológica e que preencher os requisitos exigidos para a candidatura ao cargo de Reitor do Instituto Federal; ou possua o mínimo de 2 (dois) anos de exercício em cargo ou função de gestão na instituição; ou tenha concluído, com aproveitamento, curso de formação para o exercício de cargo ou função de gestão em instituições da administração pública (BRASIL, 2008).

No que se refere à estrutura organizacional dos Institutos Federais, é importante destacar que "[...] cada Instituto Federal é organizado em estrutura multicampi, com proposta orçamentária anual identificada para cada campus e a reitoria, exceto no que diz respeito a pessoal, encargos sociais e benefícios aos servidores" (BRASIL, 2008). Com o objetivo de ministrar educação profissional técnica de nível médio, ministrar cursos de formação inicial e continuada de trabalhadores, realizar pesquisas aplicadas, desenvolver atividades de extensão, estimular e apoiar processos educativos que levem à geração de trabalho e renda e à emancipação do cidadão e atuar na educação superior (cursos de tecnologia, de licenciaturas, de bacharelados e engenharia e pós-graduação lato sensu e stricto sensu), os Institutos Federais têm a função especial de ofertar educação profissional e tecnológica nas diferentes modalidades de ensino por todo o país (BRASIL, 2008).

Portanto, a finalidade, os objetivos e a missão dos Institutos Federais de Educação serão alcançados com a participação efetiva dos tomadores de decisão, dos gestores responsáveis pelas unidades administrativas detalhadas acima. Entender como estão configuradas as competências gerenciais destes atores é crucial para subsidiar uma política de desenvolvimento de pessoal com o intuito de preparar esses gestores para os papeis que cada um exerce no seu contexto de atuação, consequentemente alcançar os resultados almejados pela organização. 


\subsection{Instrumento e a coleta dos dados}

Genericamente, adotou-se uma postura em que a busca pelas respostas do estudo foi adquirida através de fatos observáveis e mensuráveis, através da aplicação de um questionário com perguntas fechadas. Para Collis e Hussey (2005) o questionário é uma lista de perguntas cuidadosamente estruturadas, escolhidas após a realização de vários testes e que tem como objetivo descobrir o que um grupo selecionado de participantes faz, pensa ou sente. Nesse sentido, tomou-se como fundamento para o questionário o framework elaborado por Quinn et al. (2015), o qual foi aplicado ao estudo, onde os sujeitos participantes da pesquisa foram convidados a participarem de uma survey via questionário autoadministrado. Para Sampieri, Callado e Lucio (2013) autoadministrado significa que o questionário foi entregue diretamente ao sujeito participante do estudo, sem intermediários e que as respostas serão assinaladas por eles. Seguindo esse parâmetro, usou-se da $41^{\text {a }}$ Reunião de Dirigentes das Instituições Federais de Educação Profissional e Tecnológica (Reditec 2017), que aconteceu entre os dias 20, 21, 22 e 23 de novembro de 2017, no município de João Pessoa - PB. A Reditec é um momento onde os gestores dos Institutos Federais, Cefets e Colégio Pedro II se encontram anualmente para discutir sobre o contexto educacional e delinearem políticas de gestão, consolidar projetos institucionais e parcerias. O evento é direcionado para reitores, pró-reitores, diretores sistêmicos e diretores-gerais dos campi, incluindo os de Ensino e de Administração. Portanto, oportunidade ímpar para aplicar os questionários junto aos Diretores Gerais de campi dos Institutos Federais, sujeitos da pesquisa.

Foram aplicados 350 (trezentos e cinquenta) questionários com perguntas fechadas englobando dados sociais, demográficos e profissionais, além da matriz de avaliação de competências gerenciais com base em Quinn et al. (2015) com 20 afirmações, onde o respondente sinalizou seu nível de domínio e nível de frequência de uso das competências enquanto diretor geral de campus.

Para Babbie (2005) uma pesquisa de survey pode ter como objetivos gerais descrever (descobrir a distribuição de certos traços e atributos de alguma população), explicar (fazer asserções explicativas sobre a população) e explorar (fornecer um mecanismo de busca quando se está começando a investigação). Hair Jr. et al. (2005) afirmam que a survey é um procedimento usado para coletar dados primários de uma grande amostra de participantes, onde esses sujeitos sabem claramente que o propósito do estudo é coletar informações sobre seus comportamentos e/ou atitudes. Nesse sentido a pesquisa com o formato survey oferece um método que pode ser empiricamente verificado, se adequa à intersubjetividade e facilita a 
abertura da ciência, na medida em que envolve a coleta e a quantificação de dados, onde esses dados coletados se tornam fonte permanente de informações (BABBIE, 2005).

Para garantir uma maior precisão nessa etapa de coleta de dados foi necessário um questionário que possibilitasse medir corretamente as características que se deseja descobrir com o estudo. Nesse sentido esse conjunto predeterminado de perguntas criado para coletar dados dos sujeitos participantes da pesquisa (HAIR JR. et al., 2005) foi baseado nos estudos de Quinn et al. (2015), onde as competências principais associadas aos quatro quadrantes da estrutura de valores concorrentes provêm de estudos anteriores realizados por Faerman et al. (1987) e Lawrence, Lenk e Quinn (2009), os quais foram apresentadas, inicialmente, mais de 250 competências por gerentes em atividades de nível intermediário e sênior, administradores, representantes sindicais e estudiosos.

Os questionários, de acordo com o Apêndice A, foram autoadministrados, respondidos sem a presença do pesquisador (HAIR JR. et al., 2005), através de uma abordagem preliminar, sendo o ambiente da Reditec 2017 o escolhido para a coleta dos dados. Os questionários foram direcionados e respondidos pelos ocupantes da função de Direção Geral de cada campus dos Institutos Federais de Educação, sendo aquele composto de três seções ou etapas:

Seção 01 - questões de caráter sociodemográfico e profissional;

Seção 02 - nível atual de domínio das competências gerenciais; e

Seção 03 - nível de frequência de uso (importância) das competências gerenciais no exercício da função de Diretor geral.

Nas seções 02 e 03 os respondentes emitiram sua opinião em questionário auto avaliativo denominado 'matriz de avaliação de competências' composto por 20 (vinte) afirmações que descrevem práticas administrativas (competências específicas), as quais os respondentes indicaram o seu nível atual de domínio e nível de frequência de uso no desempenho de suas atividades como diretores gerais de campus. Os questionários foram estruturados através de uma escala com resposta de múltipla escolha e do tipo Likert, sendo esta de 5 (cinco) pontos variando de 1 a 5, conforme Apêndice A e descrito no quadro 07. 
Quadro 06: Pontuação da escala da matriz de avaliação de competências nos quesitos domínio e frequência de uso

\begin{tabular}{|l|c|c|}
\hline Nível de domínio & Nível de frequência de uso & Pontuação \\
\hline Nenhum & Nunca & 1 \\
\hline Baixo & Raramente & 2 \\
\hline Moderado & Ocasionalmente & 3 \\
\hline Alto & Frequentemente & 4 \\
\hline Total & Sempre & 5 \\
\hline
\end{tabular}

Fonte: elaborada pelo autor (2018), com base em Quinn et al. (2015)

O instrumento de coleta de dados dessa pesquisa (Apêndice A) é fundamentado no modelo proposto por Quinn et al. (2015) através de sua 'matriz de avaliação de competências', baseadas em quatro imperativos de ação (Colaborar, Controlar, Competir e Criar) associados a quatro modelos de gerenciamento (Relações Humanas, Processo Interno, Meta Racional e Sistema Aberto) respectivamente. Em cada modelo e imperativo de ação são propostas 5 (cinco) competências ou condutas administrativas ideais para se chegar a excelência na gestão nos respectivos modelos e imperativos de ação, totalizando 20 (vinte) competências específicas detalhadas no instrumento de pesquisa e que foram avaliadas pelos sujeitos da pesquisa. Destaca-se o quadro 06 que especifica o instrumento construído.

Quadro 07 - competências específicas do instrumento de coleta associadas aos modelos

\begin{tabular}{|c|c|c|c|}
\hline Modelo & $\begin{array}{l}\text { Imperativo de } \\
\text { ação }\end{array}$ & Foco & Competências \\
\hline \multirow{5}{*}{$\begin{array}{l}\text { Relações } \\
\text { humanas }\end{array}$} & \multirow{5}{*}{$\begin{array}{l}\text { Colaborar: } \\
\text { compromisso e } \\
\text { coesão }\end{array}$} & \multirow{5}{*}{$\begin{array}{l}\text { Ambiente interno e } \\
\text { na flexibilidade }\end{array}$} & Entender a si mesmo e os outros \\
\hline & & & Comunicar com honestidade e efetividade \\
\hline & & & Orientar e desenvolver pessoas \\
\hline & & & Gerenciar grupos e liderar equipes \\
\hline & & & Gerencias e estimular o conflito produtivo \\
\hline \multirow{5}{*}{$\begin{array}{l}\text { Sistemas } \\
\text { abertos }\end{array}$} & \multirow{5}{*}{$\begin{array}{l}\text { Criar: mudança e } \\
\text { adaptabilidade }\end{array}$} & \multirow{5}{*}{$\begin{array}{c}\text { Ambiente externo e } \\
\text { na flexibilidade }\end{array}$} & Usar o poder e a influência com ética e efetividade \\
\hline & & & Patrocinar e vender novas ideias \\
\hline & & & Estimular e promover inovação \\
\hline & & & Negociar acordos e compromissos \\
\hline & & & Implementar e sustentar a mudança \\
\hline \multirow{5}{*}{$\begin{array}{l}\text { Metas } \\
\text { racionais }\end{array}$} & \multirow{5}{*}{$\begin{array}{l}\text { Competir: } \\
\text { produtividade e } \\
\text { rentabilidade }\end{array}$} & \multirow{5}{*}{$\begin{array}{l}\text { Ambiente externo e } \\
\text { no controle }\end{array}$} & Desenvolver e comunicar uma visão \\
\hline & & & Estabelecer metas e objetivos \\
\hline & & & Motivar a si mesmo e aos outros \\
\hline & & & Projetar e organizar \\
\hline & & & Gerenciar a execução e buscar resultados \\
\hline \multirow{5}{*}{$\begin{array}{l}\text { Processos } \\
\text { internos }\end{array}$} & \multirow{5}{*}{$\begin{array}{l}\text { Controlar: } \\
\text { estabilidade e } \\
\text { continuidade }\end{array}$} & \multirow{5}{*}{$\begin{array}{l}\text { Ambiente interno e } \\
\text { no controle }\end{array}$} & Organizar fluxos de informações \\
\hline & & & Trabalhar e gerenciar entre funções \\
\hline & & & Planejar e coordenar projetos \\
\hline & & & Medir e monitorar o desempenho e a qualidade \\
\hline & & & Estimular e possibilitar a conformidade \\
\hline
\end{tabular}

Fonte: elaborada pelo autor (2018), com base em Quinn et al. (2015) 
Quinn et al. (2015) afirmam que estas etapas aplicadas em conjunto fornecem resultados mais amplos e não somente um perfil 'instantâneo' ou uma avaliação final, assim, essa configuração do perfil de competências gerenciais será baseada nas percepções dos sujeitos sobre suas experiências, forças e fraquezas atuais, podendo, dessa forma ser utilizado para criar um plano de desenvolvimento desses gestores com base nas necessidades e interesses dos indivíduos e da organização.

Todos esses questionários, conforme originalmente produzidos por Quinn et al. (2015) são parametrizados, arranjados em uma escala do tipo Likert. Nessa as respostas dos pesquisados foram colocadas em um contínuo de atitudes, onde os enunciados são planejados para medir um aspecto particular no qual o pesquisador está interessado (MAY, 2004).

Collis e Hussey (2005) afirmam que se os dados coletados são um retrato fidedigno do que está sendo estudado, se as descobertas da pesquisa representam de maneira precisa o que está acontecendo naquela situação o estudo adquire validade.

\subsection{Análise e tratamento dos dados}

Nessa seção serão apresentados a análise e tratamento dos dados, as quais ocorreram em três fases: i - exame para verificar a validade e a confiabilidade dos dados; ii estatística descritiva; e iii - análise fatorial exploratória e confirmatória do modelo. Fases essas que serão descritas e melhor explicadas adiante.

Fase I - validade e confiabilidade

Conforme Hair Jr. et al. (2005) antes de se analisar os dados coletados propriamente ditos é necessário que o pesquisador examine-os para certificar de sua validade. Sendo assim adotou-se essa prescrição dos autores e foi conduzida uma inspeção com o intuito de encontrar incoerências, os dados faltantes foram verificados e os respondentes codificados ao ingressarem no banco de dados. Para Gibbs (2009, p.16) a análise indica determinado tipo de mudança, onde se inicia uma coleta de dados e "depois se processa por meio de procedimentos analíticos, até que se transformem em uma análise clara, compreensível, criteriosa, confiável e até original”.

Para Collis e Hussey (2005) a confiabilidade da pesquisa está relacionada às suas descobertas, caso outra pesquisador repita o estudo e obtenha os mesmos resultados. Já a validade está diretamente relacionada à coleta dos dados, se estes representam a realidade do que está sendo estudado, se as descobertas retratam fielmente o que está acontecendo na 
situação (COLLIS; HUSSEY, 2005). Hair Jr. et al. (2005) complementa afirmando que a precisão está associada com o termo validade, enquanto que a coerência está ligada ao termo confiabilidade. Nesse estudo o instrumento de pesquisa, o questionário, composto por 4 (quatro) dimensões, contendo, cada uma, 5 (cinco) variáveis (competências gerenciais), passará por validação de conteúdo, além de usar o critério de confiabilidade de coerência interna.

Para validade de conteúdo e de face foi realizado um pré-teste com 10 (dez) colaboradores, sendo 3 (Três) Doutores em Administração, 2 (Dois) Mestres em Administração e 5 (Cinco) mestrandos em Administração, onde esses colaboradores avaliaram se os itens do questionário são representativos quanto ao conteúdo e cobrem as dimensões do construto, além de verificarem a clareza dos enunciados dos itens, confirmando ou não o que eles se propõe a medir.

Fase II - estatística descritiva conforme modelo

A estatística descritiva entendida numa perspectiva de análise de dados e também como um conjunto de técnicas (COOPER; SCHINDLER, 2011) foi usada substancialmente no estudo. Conforme descrito anteriormente a coleta de dados foi predominantemente quantitativa, gerando dessa forma valores numéricos que representam o número total de observações ou frequências para as variáveis indicadas na abordagem de valores concorrentes proposta por Quinn et al. (2015). A análise exploratória de dados tem o intuito de resumir, descrever ou apresentar dados em tabelas, quadros, gráficos ou alguma outra forma diagramática, possibilitando um maior discernimento dos padrões e relações que não estariam visíveis em dados não analisados (COLLIS; HUSSEY, 2005).

Técnicas estatísticas foram usadas para a apresentação de frequências. Para Collis e Hussey (2005, p.188) uma frequência é "um valor numérico que representa o número total de observações para uma variável que está sendo estudada". Portanto, apresentar os dados dessas frequências coletadas em formas de tabelas, quadros, tabulações cruzadas, diagramas e gráficos foram adequados para a análise dos dados quantitativos coletados. As chamadas distribuições de frequências têm o objetivo de demonstrar o número de respostas associadas com cada valor de uma variável (HAIR Jr. et al., 2005). Para descrever esse conjunto de dados por meio de um único valor foi necessário calcular a média aritmética $\left({ }^{\bar{x}}=\frac{\sum x_{i}}{n}\right)$, uma medida de tendência central; pode-se calcular ainda a frequência relativa de percentagem $\left(F \%=\frac{F}{F_{t}} \cdot 100\right)$ sendo necessário ainda descrever a disseminação dos valores na distribuição dos 
dados coletados, a chamada mensuração de dispersão, especificamente foi calculado o desvio padrão $\left(s=\sqrt{\frac{\sum\left(x_{i}-\bar{x}\right)^{2}}{n-1}}\right)$, o qual “descreve a dispersão da variabilidade dos valores de distribuição da amostra a partir da média" e "indica algo sobre o nível de concordância entre os respondentes quando eles respondem uma determinada questão" (HAIR Jr. et al., 2005, p.273).

Os dados coletados através da aplicação dos questionários foram inseridos em um arquivo do Microsoft Office Excel 2010 e importados para o tratamento e análise dos dados utilizando o software IBM SPSS Statistics Desktop [US], versão 23.

Fase III - análise fatorial exploratória e confirmatória

A análise fatorial, de uma forma geral, está incluída em um conjunto de técnicas estatísticas de análise multivariada e que tem o objetivo de reduzir a um número administrável, muitas variáveis que formam um grupo e se sobrepõem às características de mensuração (COOPER; SCHINDLER, 2011; VIDAL, 2016). A análise fatorial pode ser uma análise fatorial exploratória e/ou confirmatória. A análise fatorial exploratória é usada quando não se possui uma teoria específica que determine a natureza e quantidade de fatores subjacentes aos dados (HAIR Jr. et al., 2005).

Para confirmar a estrutura fatorial hipotética demonstrada pelo framework realizou-se uma análise fatorial confirmatória, com o objetivo de verificar se a estrutura dos fatores se adequava às variáveis observadas pelo instrumento utilizado e confirmar o modelo teórico. Assim, conforme Hair Jr. et al. (2005), a análise fatorial confirmatória é usada quando se tem um modelo que especifica claramente quantos fatores estão subjacentes aos itens e quais itens que possuem cargas em qual fator, permitindo, também, testar se os dados obtidos a partir de uma amostra se ajustam bem a essa estrutura teórica hipotetizada pelo modelo.

Inicialmente houve a necessidade de aplicar o teste Kaizer-Meyer-Olkin (KMO) para verificar a adequação da amostra. Em seguida foi levado em consideração o teste de esfericidade Bartlett no qual examina se a matriz é proporcional à matriz identidade (FIELD, 2009). Para Field (2009) a estatística KMO mede a adequação da amostra e varia de 0 a 1 , onde o 0 (zero) indica uma análise inadequada dos fatores, portanto uma difusão no padrão da correlações. Já valores próximos de 1 (um) denotam que os padrões de correlações são relativamente compactos. Assim, valores entre 0,5 e 0,7 são considerados medíocres, valores entre 0,7 e 0,8 são bons, valores entre 0,8 e 0,9 são ótimos e valores acima de 0,9 são excelentes (FIELD, 2009). 
Os autovalores (eigenvalues) são a soma das variâncias dos valores do fator e quando dividido pelo número de variância gera uma estimativa da quantidade de variação total explicada pelo fator (COOPER; SCHINDLER, 2011). As comunalidades, que, conforme Cooper e Schindler (2011), são conceituadas como as estimativas da variância em cada variável que é explicada por dois ou mais fatores, também foram observadas.

Foi realizada uma análise das dimensões que compõem o questionário (Colaborar, Competir, Criar e Controlar) através do método de rotação Varimax. Outra etapa colocada em prática foi a análise se cada afirmativa das quatro dimensões fornecem "factor loadings" (cargas fatoriais) por meio de sua correlação com outras afirmativas.

Para garantir a confiabilidade do instrumento de pesquisa foi calculado a confiabilidade de coerência interna através do alfa de coeficiente ou alfa de Cronbach, o qual é obtido através da média dos coeficientes de todas as combinações possíveis das metades divididas ( $\alpha=\frac{K}{K-1}\left[1-\frac{\sum S_{t}^{2}}{S_{T}^{2}}\right]$ ), considerando-se como confíavel a variação do coeficiente alfa estando entre 0,7 a 0,9 onde a intensidade da associação será caracterizada como "boa", "muito boa" ou "excelente".

As medidas de ajuste absoluto e os índices de ajuste comparativo foram utilizados para a avaliação do modelo fatorial, levando em consideração os resultados obtidos com a aplicação dos resultados dos testes de Qui-quadrado, RMSEA (Root Mean Square Error of Approximation), CFI (Comparative Fit Index), TLI (Tucker-Lewis index) e GFI (Goodness of it Index). Considerou-se que os valores absolutos de Curtose $(\mathrm{Ku}>7)$ e de Assimetria $(\mathrm{SK}<3)$ não indicavam desvios severos à distribuição normal das respostas e consequentemente sensibilidade para a medição das variáveis conforme o modelo. 


\section{ANÁLISE E DISCUSSÃO DOS RESULTADOS}

Nesta seção serão apresentados os resultados do estudo, demonstrando, inicialmente como se chegou a uma confiabilidade e validade dos dados coletados. $\mathrm{Na}$ sequência apresentar-se-á uma análise fatorial confirmatória do modelo utilizado no estudo e por fim, para alcançar os objetivos do estudo serão descritas as variáveis relevantes ao contexto da pesquisa.

\subsection{Análises preliminares necessárias}

Para alcançar o objetivo desse estudo, analisar a configuração do perfil de competências gerenciais foi necessário aplicar um questionário aos sujeitos da pesquisa, conforme detalhado. O questionário foi aplicado de maneira autoadministrada, sem intermediários e as respostas marcadas pelos sujeitos e recolhidos posteriormente. No entanto, após recolhimento e análises dos questionários devolvidos, foi necessário eliminar os questionários incompletos ou totalmente sem resposta alguma.

No que se refere ao instrumento de pesquisa propriamente dito, procedeu-se a verificação da validade teórica. Onde os juízes, doutores, mestres e mestrandos na área de Administração avaliaram se os 20 itens representam adequadamente o construto e a compreensão dos itens, análise semântica, conforme recomenda Pasquali (2010). Aqueles decidiram que o instrumento tem evidências de validade teórica, no entanto propuseram modificações nas construções das assertivas que representam as 20 (vinte) variáveis do modelo, as quais foram devidamente registradas e adequadas.

Para análise tabulação dos dados provenientes da aplicação do questionário, usouse o software Microsoft Office ${ }^{\circledR}$ Excel, versão 2010, para tabular os dados em planilha, em seguida os dados inseridos no software IBM SPSS Statistics Desktop [US], versão 23, através de importação da planilha, buscando inicialmente todos os outliers e missing, eliminando dados faltantes. 


\subsection{Análise descritiva inicial dos resultados obtidos}

Os dados obtidos relativos aos diretores gerais de campus dos institutos federais foram provenientes da primeira parte do questionário, das questões 1 (um) a 9 (nove), permitindo conhecer desde o instituto do qual faz parte, o tempo em que atua na instituição como funcionário público e como gestor do campus, o cargo que ocupa, passando pela caracterização desses sujeitos quanto ao sexo, faixa etária, estado civil, nível de escolaridade até a área de formação de cada respondente. E na segunda parte os respondentes declararam o quanto usam no dia a dia de sua função como diretor geral de campus e o quanto dominam cada competência descrita pela abordagem de valores concorrentes na gestão para ser um líder gerencial efetivo.

É importante lembrar que os dados da pesquisa foram obtidos através de observações independentes em que os sujeitos (ocupantes da função de Diretor Geral de campus dos IF's) responderam apenas uma vez o instrumento de pesquisa, foram dados nãopareados. Portanto, pode-se usar a regra que determina a razão entre sujeitos e variáveis, que recomenda usar a razão 10:1 (HAIR Jr. et. al, 2015). Isso implica que para cada variável observável é necessário ter, no mínimo, 10 (dez) respondentes, no caso desse estudo se enquadra dentro dos parâmetros.

Conforme descrito em seção anterior, foram aplicados 350 questionários, no entanto, após recolhimento e análises prévias, restaram 241 ( $N$ amostral) questionários devidamente assinalados conforme exigia o estudo. Portanto, a amostra do estudo retrata bem as características que representa a população, sendo adequada para um nível de confiança de 0,95 (ou 95\%), $\alpha=0,05$, que exigiria um $N$ amostral de 229 sujeitos, o qual foi ultrapassado, conforme o tamanho amostral selecionado e que foi determinado usando o fator de correção para população finita proposto por Triola (2013).

Participaram como respondentes do estudo os servidores ocupantes do cargo de direção geral de campus de todos os institutos federais do Brasil, conforme detalhado na Tabela 03. 
Tabela 03 - representação dos respondentes por instituto federal

\begin{tabular}{|c|c|c|c|c|}
\hline Or. & Organização & $\begin{array}{c}\text { Quantidade de } \\
\text { Campus/Diretores }\end{array}$ & $\begin{array}{l}\text { Frequência de } \\
\text { respondentes }\end{array}$ & $\begin{array}{c}\text { Percentagem } \\
(\%)\end{array}$ \\
\hline 1 & Instituto Federal do Acre & 6 & 3 & 50,00 \\
\hline 2 & Instituto Federal de Alagoas & 16 & 8 & 50,00 \\
\hline 3 & Instituto Federal do Amapá & 5 & 2 & 40,00 \\
\hline 4 & Instituto Federal do Amazonas & 15 & 5 & 33,33 \\
\hline 5 & Instituto Federal da Bahia & 23 & 10 & 43,48 \\
\hline 6 & Instituto Federal Baiano & 37 & 1 & 2,70 \\
\hline 7 & Instituto Federal do Ceará & 31 & 7 & 22,58 \\
\hline 8 & Instituto Federal de Brasília & 11 & 10 & 90,91 \\
\hline 9 & Instituto Federal do Espírito Santo & 22 & 9 & 40,91 \\
\hline 10 & Instituto Federal de Goiás & 14 & 11 & 78,57 \\
\hline 11 & Instituto Federal Goiano & 12 & 6 & 50,00 \\
\hline 12 & Instituto Federal de Mato Grosso & 19 & 13 & 68,42 \\
\hline 13 & Instituto Federal do Maranhão & 28 & 9 & 32,14 \\
\hline 14 & Instituto Federal do Mato Grosso do Sul & 10 & 5 & 50,00 \\
\hline 15 & Instituto Federal de Minas Gerais & 18 & 4 & 22,22 \\
\hline 16 & Instituto Federal do Norte de Minas Gerais & 11 & 4 & 36,36 \\
\hline 17 & Instituto Federal do Sudeste de Minas & 10 & 8 & 80,00 \\
\hline 18 & Instituto Federal do Sul de Minas & 8 & 7 & 87,50 \\
\hline 19 & Instituto Federal do Triângulo Mineiro & 9 & 8 & 88,89 \\
\hline 20 & Instituto Federal do Pará & 18 & 9 & 50,00 \\
\hline 21 & Instituto Federal da Paraíba & 18 & 4 & 22,22 \\
\hline 22 & Instituto Federal do Paraná & 25 & 14 & 56,00 \\
\hline 23 & Instituto Federal de Pernambuco & 15 & 10 & 66,67 \\
\hline 24 & Instituto Federal do Sertão Pernambucano & 7 & 4 & 57,14 \\
\hline 25 & Instituto Federal do Piauí & 20 & 11 & 55,00 \\
\hline 26 & Instituto Federal do Rio de Janeiro & 15 & 2 & 13,33 \\
\hline 27 & Instituto Federal Fluminense & 12 & 4 & 33,33 \\
\hline 28 & Instituto Federal do Rio Grande do Norte & 20 & 8 & 40,00 \\
\hline 29 & Instituto Federal do Rio Grande do Sul & 17 & 5 & 29,41 \\
\hline 30 & Instituto Federal Farroupilha & 11 & 5 & 45,45 \\
\hline 31 & Instituto Federal Sul-rio-grandense & 14 & 7 & 50,00 \\
\hline 32 & Instituto Federal de Rondônia & 9 & 2 & 22,22 \\
\hline 33 & Instituto Federal de Roraima & 5 & 3 & 60,00 \\
\hline 34 & Instituto Federal de São Paulo & 38 & 3 & 7,89 \\
\hline 35 & Instituto Federal de Santa Catarina & 22 & 7 & 31,82 \\
\hline 36 & Instituto Federal Catarinense & 15 & 5 & 33,33 \\
\hline 37 & Instituto Federal de Sergipe & 9 & 5 & 55,56 \\
\hline \multirow[t]{2}{*}{38} & Instituto Federal do Tocantins & 11 & 3 & 27,27 \\
\hline & Total & 606 & 241 & 39,77 \\
\hline
\end{tabular}

Fonte: elaborada pelo autor (2018), com base nos dados da pesquisa 
É importante destacar que o estudo conseguiu representatividade de todos os 38 (trinta e oito) institutos federais em funcionamento no país. Levando-se em consideração o total de campi desses institutos, dos 606 (seiscentos e seis) obteve-se um número considerável de respondentes, chegando aos 241 (duzentos e quarenta e um), conforme tabela 03, equivalente a 39,77\% desse total. Assim, a amostra é considerada altamente representativa. Ressalta-se, porém, a ínfima representatividade dos Institutos Federais Baiano e de São Paulo.

A questão seguinte do instrumento de pesquisa procurou entender qual o cargo que ocupa esses sujeitos, pois conforme legislação vigente, a função de diretor geral de campus dos institutos federais pode ser ocupada por qualquer categoria de servidor de nível superior, desde que atenda às regras, a Tabela 04 demonstra claramente os resultados obtidos.

Tabela 04 - cargo que ocupa como servidor público

\begin{tabular}{rlrc}
\hline Or. & Cargo & Frequência & Percentagem (\%) \\
\hline 1 & Professor do Ensino Básico, Técnico e Tecnológico & 217 & 90,04 \\
2 & Técnico Administrativo em Educação & 24 & 9,96 \\
\hline \multicolumn{2}{c}{ Total } & $\mathbf{2 4 1}$ & $\mathbf{1 0 0 , 0 0}$ \\
\hline
\end{tabular}

Fonte: elaborada pelo autor (2018), com base nos dados da pesquisa

Nota-se que o servidor docente é quem predomina na ocupação do cargo de direção geral, sendo um pouco mais de $90 \%$ dentre os campi e sujeitos pesquisados. Indiscutivelmente o docente se torna a figura principal nesse tipo de organização educacional e ascende aos cargos de direção muito mais facilmente perante os servidores técnicos administrativos.

Fleck e Pereira (2011) ao verificarem o perfil de competências gerenciais de professores gestores de programas de pós-graduação em instituições federais percebeu-se que aqueles são mais direcionados para administrar tarefas, preocupam-se com as regras e repassar a equipe em que atua. Perfil este que pode ser diferente ou não quando gerenciado por não docentes, sejam em universidades, sejam nos campi dos institutos federais de educação.

Outro fator importante que deve ser considerado no estudo é o tempo de atuação como servidor público do instituto federal. Nota-se pela tabela 05 que o índice de sujeitos que são servidores há mais de 16 anos é proporcionalmente relevante, representa $28,63 \%$ do total. 
Tabela 05 - tempo que atua como servidor público

\begin{tabular}{lcc}
\multicolumn{1}{c}{ Tempo } & Frequência & Percentagem (\%) \\
\hline Até 3 anos & 9 & 3,73 \\
Entre 4 e 7 anos & 70 & 29,05 \\
Entre 8 e 11 anos & 82 & 34,02 \\
Entre 12 e 15 anos & 11 & 4,56 \\
Há mais de 16 anos & 69 & 28,63 \\
\hline \multicolumn{1}{c}{ Total } & $\mathbf{2 4 1}$ & $\mathbf{1 0 0 , 0 0}$ \\
\hline
\end{tabular}

Fonte: elaborada pelo autor (2018), com base nos dados da pesquisa

O outro extremo evidencia que $3,73 \%$ dos diretores gerais ainda não conseguiram ao menos sair do estágio probatório e já estão sendo gestores de campus, o que vai demandar alguma característica específica da abordagem de valores concorrentes. No outro segmento percebe-se que $63,07 \%$ os servidores que são gestores estão atuando no serviço público entre 4 (quatro) e 11 (onze) anos. Levando em consideração o fator tempo de atuação no serviço público, destaca-se o estudo de Gloria Junior, Zouain e Almeida (2014) que, ao descreverem as competências técnicas e habilidades necessárias para um perito criminal federal no exercício da função de chefe de unidade de perícia da Polícia Federal inferiram que o tempo de atuação na função de perícia não é fator determinante para que o gestor possa dominar ou não determinadas competências.

O quesito experiência é um fator importante na configuração do perfil de competências gerenciais dos gestores de campus dos institutos federais, veja como se configura a experiência dos servidores enquanto gestores, seguem dados obtidos na tabela 06.

Tabela 06 - tempo que atua como diretor geral

\begin{tabular}{lcc}
\hline \multicolumn{1}{c}{ Tempo } & Frequência & Percentagem (\%) \\
\hline Até 1 ano & 72 & 29,88 \\
Entre 2 e 3 anos & 81 & 33,61 \\
Entre 4 e 5 anos & 55 & 22,82 \\
Entre 6 e 7 anos & 22 & 9,13 \\
Há mais de 8 anos & 11 & 4,56 \\
\hline \multicolumn{1}{c}{ Total } & $\mathbf{2 4 1}$ & $\mathbf{1 0 0 , 0 0}$ \\
\hline
\end{tabular}

Fonte: elaborada pelo autor (2018), com base nos dados da pesquisa

Estima-se que esse percentual apresentado na tabela 06 evidencia que a maior parte dos diretores gerais está cumprindo seu primeiro ciclo de gestão, quer dizer, $63,49 \%$ dos diretores estão nos cargos há menos de 4 anos, os demais, 36,51\%, estão entre 4 e 8 anos. Genericamente, os campi são novos, houve nos últimos 8 (oito) anos uma expansão 
significativa e surgimento de novos campi na rede federal de educação profissional e tecnológica o que demandou a efetivação de gestores para essas unidades. O que se pode destacar é que em uma determinada pesquisa no contexto do setor público federal, constatouse que há diferenças quanto ao nível de domínio de competências de sujeitos gestores mais jovens e com menos tempo de experiência e outros tipos de chefes com maior tempo de atuação no serviço público e também em gestão (GLORIA JUNIOR; ZOUAIN; ALMEIDA, 2014).

A seguir são apresentados os dados sociodemográficos que caracterizam os gestores quanto ao sexo, faixa etária, estado civil e nível de escolaridade. Esse conjunto de variáveis torna-se importante indicador de como os sujeitos estão caracterizados de forma mais abrangente, podem não fazer parte dos objetivos específicos e geral do estudo, de maneira explícita, no entanto, são de suma importância para consubstanciar as análises que se seguem e as conclusões que respondem ao problema de pesquisa. Esses dados estão descritos de maneira geral na tabela 07 e apresentam as frequências e níveis percentuais para cada variável analisada, conforme parâmetros.

Tabela 07 - características gerais dos respondentes

\begin{tabular}{|c|c|c|c|}
\hline \multicolumn{2}{|c|}{ Características } & \multirow{2}{*}{$\begin{array}{c}\text { Frequência } \\
46\end{array}$} & \multirow{2}{*}{$\begin{array}{c}\text { Percentagem (\%) } \\
19,09 \%\end{array}$} \\
\hline Sovo & Feminino & & \\
\hline SCגU & Masculino & 195 & $80,91 \%$ \\
\hline & & 241 & 100,00 \\
\hline \multirow{7}{*}{ Faixa etária } & Até 20 anos. & 0 & $0,00 \%$ \\
\hline & Entre 21 e 30 anos. & 13 & $5,39 \%$ \\
\hline & Entre 31 e 40 anos. & 79 & $32,78 \%$ \\
\hline & Entre 41 e 50 anos. & 83 & $34,44 \%$ \\
\hline & Entre 51 e 60 anos. & 55 & $22,82 \%$ \\
\hline & 61 anos ou mais. & 11 & $4,56 \%$ \\
\hline & & 241 & 100,00 \\
\hline \multirow{5}{*}{ Estado civil } & Casado(a) & 196 & $81,33 \%$ \\
\hline & Solteiro(a). & 34 & $14,11 \%$ \\
\hline & Divorciado(a) & 11 & $4,56 \%$ \\
\hline & Viúvo(a). & 0 & $0,00 \%$ \\
\hline & & 241 & $\begin{array}{r}\mathbf{1 0 0 , 0 0} \\
\text { continua... }\end{array}$ \\
\hline
\end{tabular}




\begin{tabular}{clcc} 
& Ensino superior & 5 & $2,07 \%$ \\
Nível de & Especialização & 25 & $10,37 \%$ \\
escolaridade & Mestrado & 105 & $43,57 \%$ \\
& Doutorado & 100 & $41,49 \%$ \\
& Pós-doutorado & 6 & $2,49 \%$ \\
& & $\mathbf{2 4 1}$ & $\mathbf{1 0 0 , 0 0}$ \\
\hline
\end{tabular}

Fonte: elaborada pelo autor (2018), com base nos dados da pesquisa

A tabela 07 revela inicialmente um dado que merece reflexão, pois 80,91\% dos servidores que ocupam o cargo de direção geral de campi são do sexo masculino. Por mais que não seja objeto de estudo da pesquisa, a temática sucinta questionamentos e proposições. Porém, uma pesquisa realizada em organizações diversas da Austrália identificou oito funções gerenciais que os gerentes devem exibir se quiserem ser eficazes e concluiu que, quanto ao gênero dos gerentes e outros significatidos (equipe, colegas e chefe) foram relacionados e não houve diferenças significativas na medida em que os oito papéis foram exibidos nem o nível de efetividade dos gerentes do sexo masculino e feminino (VILKINAS, 2000)

Ouro quesito a se destacar é a faixa etária desses ocupantes da função de direção geral, a tabela 07 evidencia que $67,22 \%$ dos sujeitos têm entre 31 e 50 anos, o que pode sugerir uma relativa experiência profissional, característica de relativa importância para as tomadas de decisões no dia a dia da direção geral de campus. Os diferentes pesos que cada competência assume no perfil do líder gerencial é resultado de tudo aquilo que cada um é e foi sendo vivenciado, assim como aprendido através das experiências na própria vida (BERGAMINI, 2012).

O estado civil predominante no perfil dos gestores é casado, sendo eles em um total de 196, equivalente a $81,33 \%$ dos sujeitos pesquisados. Outra variável que pode influenciar diretamente na configuração do perfil de competências gerenciais dos diretores gerais de campus é o nível de escolaridade. Nota-se que a maioria absoluta dos diretores gerais tem Mestrado ou Doutorado, equivalente a $85,05 \%$ do total de sujeitos pesquisados, denotando um alto grau de instrução.

Estabelecidas e destacadas as considerações iniciais sobre esse perfil geral dos diretores de campi dos Institutos Federais, chega-se ao ponto crucial e determinante para se alcançar os objetivos específicos do estudo e consequentemente o objetivo geral. Nesse sentido destacam-se na seguinte as médias e os desvios padrão das 20 (vinte) competências específicas da abordagem de valores concorrentes, conforme resultados obtidos na aplicação do questionário. 
Faz-se importante mencionar que o sujeito respondente deveria assinalar seu nível de domínio numa escala do tipo Likert, de cinco pontos, que variava de 1 (Nenhum domínio) a 5 (total domínio). Assim como para o nível de frequência de uso, através de uma escala que variava de 1 (nunca uso) a 5 (sempre uso). Assim ao final o respondente teria uma média para cada conjunto de 5 (cinco) competências representativas de cada fator ou construto ou variável latente (Colaborar, Criar, Competir e Controlar). A média representativa do modelo de relações humanas corresponde as assertiva de 1 a 5; do modelo sistema aberto as competências de 6 a 10; do modelo de meta racional as competências de 11 a 15; e por fim, as afirmativas 16 a 20 são representativas do modelo de processo interno.

Nas seções que seguem serão analisados os dados conforme as dimensões do modelo e suas respectivas competências, ao final, será descrito a configuração geral do perfil de competências dos diretores gerais quanto ao nível de domínio e quanto à frequência de uso das 20 (vinte) competências para se chegar a maestria gerencial, conforme preconiza Quinn et al. (2015) e sua abordagem de valores concorrentes na gestão.

Em todas as demonstrações de resultados obtidos no estudo foram descritas as médias e os respectivos desvios padrões, pois, conforme fundamenta Field (2013) o desvio padrão é considerado uma medida de quão bem a média representa os dados. Nas seções posteriores o foco será a caracterização de cada dimensão e suas respectivas competências, assim como do modelo como um todo, de maneira geral, demonstrando assim, a caracterização do perfil de competências gerenciais dos diretores gerais de campi dos institutos federais de educação.

\subsection{Análise descritiva da dimensão relações humanas}

O fator relações humanas no âmbito da abordagem de valores concorrentes proposto por Quinn et al. (2015) tem como premissa a criação e sustentação do compromisso e da coesão no âmbito organizacional. A tabela 08 descreve a percepção dos sujeitos especificamente relacionada ao imperativo de ação colaborar, com suas respectivas competências. 
Tabela 08 - média e desvio padrão da dimensão relações humanas

\begin{tabular}{|c|c|c|c|c|c|c|}
\hline \multirow{2}{*}{\multicolumn{2}{|c|}{ Competências do fator relações humanas }} & \multicolumn{2}{|c|}{$\begin{array}{l}\text { Nível de } \\
\text { Domínio }\end{array}$} & \multicolumn{2}{|c|}{$\begin{array}{c}\text { Nível de } \\
\text { frequência de } \\
\text { Uso } \\
\end{array}$} & \multirow{2}{*}{$\begin{array}{c}\text { Diferença } \\
\text { entre as } \\
\text { médias } \\
\text { (Uso e } \\
\text { Domínio) }\end{array}$} \\
\hline & & Média & $\begin{array}{l}\text { Desvio } \\
\text { Padrão }\end{array}$ & Média & $\begin{array}{l}\text { Desvio } \\
\text { Padrão }\end{array}$ & \\
\hline Comp1 & Entender a si mesmo e os outros & 3,88 & ,604 & 4,24 & ,646 & 0,36 \\
\hline Comp2 & $\begin{array}{l}\text { Comunicar com honestidade e } \\
\text { efetividade }\end{array}$ & 4,21 &, 590 & 4,46 & ,612 & 0,25 \\
\hline Comp3 & Orientar e desenvolver pessoas & 3,80 & ,632 & 4,14 & ,643 & 0,34 \\
\hline Comp4 & Gerenciar grupos e liderar equipes & 3,86 & ,621 & 4,12 & ,702 & 0,26 \\
\hline Comp5 & $\begin{array}{l}\text { Gerenciar e estimular o conflito } \\
\text { produtivo }\end{array}$ & 3,63 &, 651 & 3,87 & ,747 & 0,24 \\
\hline
\end{tabular}

Fonte: elaborada pelo autor (2018), com base nos dados da pesquisa

Nota-se que a maior média, tanto no nível de domínio quanto na frequência de uso das referidas competências, conforme tabela 08 , foi comunicar com honestidade e efetividade, com média $=4,21$ para domínio e 4,46 para frequência de uso. Comunicar com honestidade $e$ efetividade está no centro de todas as outras competências, pois a comunicação denota troca de informações, fatos, ideias e significados (QUINN et al., 2015). Agora o ponto crítico dentro da dimensão foi gerenciar e estimular o conflito produtivo, que ficou com os menores índices, com média $=3,63$ para nível de domínio e 3,87 para frequência de uso. Pode-se inferir que os gestores de campus dos institutos federais não se consideram aptos ou não costumam estimular pessoas e grupos a trabalharem juntos para resolver problemas de maneira criativa e desenvolver soluções integradas, conforme preconizam os autores do modelo.

Infere-se ainda que as diferenças de médias entre nível de frequência de uso e nível de domínio das cinco competências da dimensão não são altamente discrepantes, sendo a variável entender a si mesmo e os outros como a maior. No geral os gestores se autoavaliaram como detentores de um nível de domínio abaixo do que é exigido nas praticas administrativas da função de direção geral relativas às cinco competências da dimensão relações humanas.

Os gestores, quando focados na dimensão relações humanas, se preocupam com as pessoas e com os grupos, além de buscarem permitir a flexibilidade para ajudar os colaboradores a crescer e se desenvolverem na organização do qual faz parte (QUINN et al., 2015). 


\subsection{Análise descritiva da dimensão processo interno}

$\mathrm{O}$ quadrante a que se refere o processo interno tem como imperativo de ação controlar, com foco $\mathrm{n}$ estabelecimento e manutenção da estabilidade e da continuidade, portanto, conforme a abordagem de valores concorrentes vai existir o paradoxo entre a necessidade de adaptação e suporte externo (QUINN et al., 2015). A tabela 09 deixa visível a percepção dos diretores gerais sobre as competências inerentes ao fator processo interno, equivalentes às funções de monitor e coordenador.

Tabela 09 - média e desvio padrão da dimensão processo interno

\begin{tabular}{|c|c|c|c|c|c|c|}
\hline \multirow{2}{*}{\multicolumn{2}{|c|}{ Competências do fator processo interno }} & \multicolumn{2}{|c|}{$\begin{array}{l}\text { Nível de } \\
\text { Domínio }\end{array}$} & \multicolumn{2}{|c|}{$\begin{array}{c}\text { Nível de } \\
\text { frequência de } \\
\text { Uso }\end{array}$} & \multirow{2}{*}{$\begin{array}{c}\text { Diferença } \\
\text { entre as } \\
\text { médias } \\
\text { (Uso e } \\
\text { Domínio) }\end{array}$} \\
\hline & & Média & $\begin{array}{l}\text { Desvio } \\
\text { Padrão }\end{array}$ & Média & $\begin{array}{l}\text { Desvio } \\
\text { Padrão }\end{array}$ & \\
\hline Comp6 & Organizar fluxos de informações & 3,57 & ,710 & 3,92 & ,723 & 0,35 \\
\hline Comp7 & Trabalhar e gerenciar entre funções & 3,68 & ,661 & 3,89 & ,707 & 0,21 \\
\hline Comp8 & Planejar e coordenar projetos & 3,61 & ,687 & 3,85 & ,689 & 0,24 \\
\hline Comp9 & $\begin{array}{l}\text { Medir e monitorar o desempenho e a } \\
\text { qualidade }\end{array}$ & 3,35 &, 760 & 3,64 & ,767 & 0,29 \\
\hline Comp10 & $\begin{array}{l}\text { Estimular e possibilitar a } \\
\text { conformidade }\end{array}$ & 3,85 & 637 & 4,13 & ,661 & 0,28 \\
\hline
\end{tabular}

Fonte: elaborada pelo autor (2018), com base nos dados da pesquisa

Destaca-se das informações da tabela 09 a competência estimular e possibilitar a conformidade, que apresenta os maiores escores no nível de domínio, assim como no nível de frequência de uso, com médias de 3,85 e 4,13, respectivamente. Para Quinn et. al (2015) essa competência indica o quanto os membros da organização e a própria organização cumprem regras, políticas e procedimentos formais.

Dentre as competências do quadrante a que apresentou menores níveis de domínio e frequência de uso foi medir e monitorar o desempenho e a qualidade, apresentando uma média de 3,35 para o domínio e 3,64 para frequência de uso. Isso significa que os gestores de campi não demonstram um alto grau de importância para suas atividades diárias e ao mesmo tempo não se percebem detentores de capacidades para o uso de métricas que avaliem o desempenho no sentido de alcançar resultados críticos no ambiente organizacional. As três primeiras competências ficaram entre na media das outras, de uma forma geral, elas são práticas administrativas voltadas para as diferentes maneiras de se executar tarefas. 


\subsection{Análise descritiva da dimensão meta racional}

Meta racional significa que o gestor deve ter como imperativo de ação competir, enfatizando a importância da visão, da definição de metas e da execução para competir de maneira efetiva (QUINN et al., 2015). Assim acaba que promovendo mais uma vez paradoxos, o que deve ser entendido como algo positivo, reafirmando mais uma vez as proposições defendidas pelos autores. Pois, nesse quadrante, conforme Quinn et al. (2015), um verdadeiro líder gerencial deve buscar equilíbrio entre aumentar a produtividade e a lucratividade enquanto se cria e se sustenta o compromisso dos funcionários. A tabela 10 mostra os resultados obtidos pela pesquisa justamente das competências que geram essa tensão dentro do fator meta racional.

Tabela 10 - média e desvio padrão da dimensão meta racional

\begin{tabular}{|c|c|c|c|c|c|c|}
\hline & \multirow{2}{*}{ Competências do modelo } & \multicolumn{2}{|c|}{$\begin{array}{l}\text { Nível de } \\
\text { Domínio }\end{array}$} & \multicolumn{2}{|c|}{$\begin{array}{c}\text { Nível de } \\
\text { frequência de } \\
\text { Uso } \\
\end{array}$} & \multirow{2}{*}{$\begin{array}{c}\text { Diferença } \\
\text { entre as } \\
\text { médias } \\
\text { (Uso e } \\
\text { Domínio) }\end{array}$} \\
\hline & & Média & $\begin{array}{l}\text { Desvio } \\
\text { Padrão }\end{array}$ & Média & $\begin{array}{l}\text { Desvio } \\
\text { Padrão }\end{array}$ & \\
\hline Comp11 & Desenvolver e comunicar uma visão & 3,70 & ,703 & 4,00 & ,698 & 0,30 \\
\hline Comp12 & Estabelecer metas e objetivos & 3,76 & ,695 & 3,98 & ,689 & 0,22 \\
\hline Comp13 & Motivar a si mesmo e aos outros & 3,96 & 670 & 4,20 &, 720 & 0,24 \\
\hline Comp14 & Projetar e organizar & 3,71 & ,650 & 3,97 & ,638 & 0,26 \\
\hline Comp15 & $\begin{array}{l}\text { Gerenciar a execução e buscar } \\
\text { resultados }\end{array}$ & 3,69 & ,662 & 3,99 & ,636 & 0,30 \\
\hline
\end{tabular}

Fonte: elaborada pelo autor (2018), com base nos dados da pesquisa

Conforme dados obtidos e descritos na tabela 10 a competência motivar a si mesmo e aos outros, mostra-se em destaque e recebe as maiores médias quanto ao domínio $(3,96)$ e quanto ao nível de frequência de uso $(4,20)$. Motivar a si mesmo e aos outros implica fazer com quê cada uma das pessoas na organização dêem o melhor de si e, por consequência sejam mais produtivas, levando as organizações a serem mais vencedoras (QUINN et al., 2015).

As outras variáveis do modelo apresentam números de resultado de média muito próximos, o que denota uma aproximação de percepção dos sujeitos pesquisados sobre um futuro desejado, sobre a estrutura e a cultura dos institutos federais e a execução e a busca por resultados. 


\subsection{Análise descritiva da dimensão sistema aberto}

O imperativo de ação do modelo é criar, tendo como pressuposto principal a busca pela promoção da mudança e estimular a adaptabilidade, requisitos essenciais para adquirir os recursos externos necessários para a organização ter sucesso (QUINN et al., 2015). Na tabela 11 são apresentados os resultados das competências do quadrante que tendem a ressaltar a obtenção de suporte externo por meio de adaptação política e resolução criativa de problemas.

Tabela 11 - média e desvio padrão da dimensão sistema aberto

\begin{tabular}{|c|c|c|c|c|c|}
\hline \multirow{2}{*}{ Competências do modelo de sistema aberto } & \multicolumn{2}{|c|}{$\begin{array}{l}\text { Nível de } \\
\text { Domínio }\end{array}$} & \multicolumn{2}{|c|}{$\begin{array}{c}\text { Nível de } \\
\text { frequência de } \\
\text { Uso } \\
\end{array}$} & \multirow{2}{*}{$\begin{array}{c}\text { Diferença } \\
\text { entre as } \\
\text { médias } \\
\text { (Uso e } \\
\text { Domínio) }\end{array}$} \\
\hline & Média & $\begin{array}{l}\text { Desvio } \\
\text { Padrão }\end{array}$ & Média & $\begin{array}{l}\text { Desvio } \\
\text { Padrão }\end{array}$ & \\
\hline $\begin{array}{ll}\text { Comp16 } & \begin{array}{l}\text { Usar o poder e a influência com ética } \\
\text { e efetividade }\end{array}\end{array}$ & 4,33 & ,636 & 4,50 & 665 & 0,17 \\
\hline Comp17 Patrocinar e vender novas ideias & 3,97 & ,667 & 4,12 & 675 & 0,15 \\
\hline Comp18 Estimular e promover inovação & 3,66 &, 731 & 3,82 &, 740 & 0,16 \\
\hline Comp19 Negociar acordos e compromissos & 3,89 & 677 & 4,11 & ,762 & 0,22 \\
\hline Implementar e sustentar a mudança & 3,73 & ,688 & 3,87 & ,706 & 0,14 \\
\hline
\end{tabular}

Fonte: elaborada pelo autor (2018), com base nos dados da pesquisa

Para Quinn et. al (2015) usar o poder e a influência com ética e efetividade significa os verdadeiros líderes efetivos mantêm sua influência no ambiente organizacional construindo e mantendo confiança e ajudando os liderados a desempenhar em um nível de efetividade cada vez maior. Essa competência apresentou os maiores índices de média, sendo 4,33 para o nível de domínio e 4,50 para o nível de frequência de uso nas ações diárias da função de direção geral de campi dos institutos federais.

Já estimular e promover a inovação não foi considerada importante na visão dos sujeitos, pois obtiveram a menor média dentre as competências do modelo de sistema aberto, chegando a 3,66 para o nível de domínio e 3,82 para a frequência de uso. Significa dizer que os gestores de campi percebem pouca usabilidade e pouco grau de domínio quanto aos processos inovativos próprios do ser líder gerencial quanto no ambiente organizacional. 


\subsection{Análise descritiva geral das dimensões}

As quatro dimensões ou fatores ou quadrantes da estrutura de valores concorrentes na gestão assumem critérios de efetividades diferentes. O modelo de relações humanas está voltado para participação, abertura e para o compromisso moral; a dimensão sistema aberto busca inovação, adaptação, crescimento e aquisição de recursos; enquanto o quadrante meta racional se diferencia em busca de produtividade, realização, direção e clareza de meta; já o modelo de processo interno foca a estabilidade, o controle, documentação e o gerenciamento de informações (QUINN et al., 2015). A tabela 12 caracteriza os achados levando em consideração as dimensões, assim pode-se verificar com mais clareza como os gestores de instituições públicas federais de ensino percebem seu nível de domínio e o quanto eles percebem a utilização das competências do modelo no cotidiano de suas atividades gerenciais nos campi dos institutos federais de educação.

Tabela 12 - média e desvio padrão das dimensões do modelo

\begin{tabular}{|c|c|c|c|c|c|}
\hline \multirow{2}{*}{ Dimensões do modelo } & \multicolumn{2}{|c|}{$\begin{array}{l}\text { Nível de } \\
\text { Domínio }\end{array}$} & \multicolumn{2}{|c|}{$\begin{array}{c}\text { Nível de } \\
\text { frequência de Uso }\end{array}$} & \multirow{2}{*}{$\begin{array}{c}\text { Diferença entre as } \\
\text { médias } \\
\text { (Uso e Domínio) }\end{array}$} \\
\hline & Média & $\begin{array}{l}\text { Desvio } \\
\text { Padrão }\end{array}$ & Média & $\begin{array}{l}\text { Desvio } \\
\text { Padrão }\end{array}$ & \\
\hline Fator 1 Relações Humanas & 3,88 & ,428 & 4,17 & ,468 & 0,29 \\
\hline Fator 2 Processos Internos & 3,61 & ,496 & 3,89 &, 518 & 0,28 \\
\hline Fator 3 Metas Racionais & 3,77 &, 490 & 4,03 &, 500 & 0,26 \\
\hline Fator 4 Sistemas Abertos & 3,91 & ,486 & 4,08 &, 515 & 0,17 \\
\hline
\end{tabular}

Fonte: elaborada pelo autor (2018), com base nos dados da pesquisa

Analisando a tabela 12, no nível de domínio das competências, percebe-se que o menor valor encontrado de desvio padrão é de 0,428 e o maior valor de desvio padrão obtido é de 0,496. Valendo-se do mesmo raciocínio, agora no nível de frequência de uso têm-se o menor valor sendo 0,468 e o maior valor de desvio padrão no nível frequência de uso 0,518. Portanto, uma primeira análise que pode ser realizada é que existem pequenos desvios padrões, relativos ao valor da própria média, indicado que os pontos de dados estão próximos da média, assim, a média é uma representação precisa dos dados, com boa aderência.

Pode-se inferir ainda que os gestores pesquisados perceberam-se com um maior nível de domínio das competências relacionadas ao modelo de sistema aberto, apresentada média de 3,91 e com o menor nível de domínio para o modelo de processos internos, com 
média de 3,61. Já quando a análise é voltada para a frequência de uso das competências gerenciais de cada modelo é nítido o direcionamento para o modelo de relações humanas com uma média de 4,17 e o modelo de processos internos apresentando a menor média, 3,89, assim como aconteceu no nível de domínio das competências.

Outro fator importante a ser considerado é a relação entre os gaps de competências de cada modelo, o que pode denotar outras constatações e modificar a visão do perfil de competências gerenciais dos diretores gerais de campi dos institutos federais de educação. Nesse sentido, conforme tabela 12 a média do fator relações humanas foi percebida como a de maior frequência de uso, no entanto, quando se faz um comparativo com o nível de domínio das competências gerenciais do próprio fator relações humanas consegue-se demonstrar que a diferença de médias é a maior que existe $(0,29)$, podendo-se inferir que os sujeitos demonstram muito mais uma necessidade de uso do que demonstram segurança no nível conceitual e prático das competências do modelo.

Na outra extremidade têm-se um menor grau de percepção de diferenças de média entre frequência de uso e domínio, no valor de 0,17, na dimensão sistemas abertos, deste modo, os diretores gerais percebem quase semelhantemente a necessidade de uso das competências do modelo e o nível de domínio de cada prática administrativa.

Destarte, refletir sobre esses achados da pesquisa torna-se fundamental para uma análise mais aprimorada sobre o perfil de competência gerencial demonstrada pelos gestores de campi, por mais que eles demonstrem que possuem um nível mais intenso de frequência de uso das competências relacionadas ao modelo de relações humanas, isso não significa necessariamente que eles atestem domínio dessas mesmas práticas administrativas, o que ficou claro no resultado da lacuna existente entre domínio e frequência de uso da dimensão relações humanas, sendo o maior. Assim como os gestores demonstraram, através dos resultados descritos nas médias, que dominam mais as competências relacionadas ao modelo de sistema aberto, no entanto, as competências do modelo não são as mais usadas pelos gestores no seu dia a dia de trabalho como ocupante da função de direção geral de campus.

Assim para se obter uma análise mais apropriada e melhor entender a configuração do perfil de competências gerenciais dos diretores gerais de campi dos institutos federais é indispensável verificar através de um gráfico que exiba os dados coletados e ao mesmo tempo o direcionamento de cada quadrante, uma estruturação completa está posta na figura 06. 
Figura 06 - perfil de competências gerenciais na estrutura de valores concorrentes na gestão

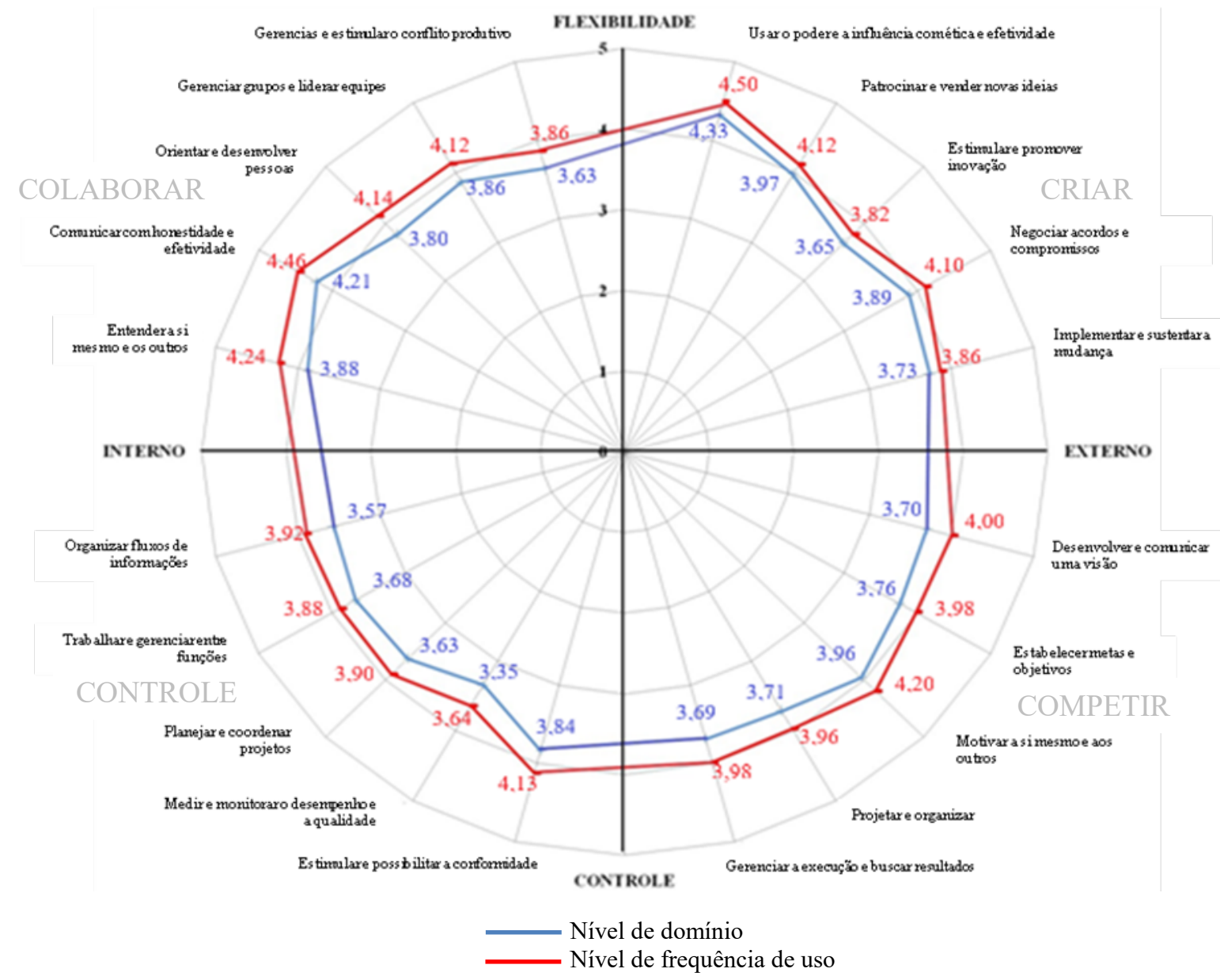

Fonte: elaborada pelo autor (2018), com base nos dados da pesquisa

A demonstração visual através na figura 06 deixa evidente, inicialmente, a preponderância do nível de frequência de uso em relação ao nível de domínio das competências gerenciais em todas as dimensões do framework. Os gestores de campi perceberam e declararam através do resultado de suas médias que eles possuem uma necessidade de uso das práticas administrativas, mas, sem estarem devidamente confortáveis quanto ao seu domínio. Consequentemente, os gestores devem se concentrar em elevar os padrões de todas as variáveis do modelo não somente para serem aptos tecnicamente, mas para agirem como gerentes-mestres, através de atitudes mais complexas e com a integração de pensamentos e possibilidades de tomada de decisão de modos inovadores que atendem às necessidades da situação, usando de competências aparentemente contrárias (QUINN et. al, 2015).

Seguindo essa linha de pensamento dos propositores da abordagem de valores concorrentes e corroborando com os achados encontrados, Bergamini (2012) afirma que tudo 
aquilo que cada um realiza, decide ou o torna evidente, vai depender das características próprias do conjunto de competências que possui ou não. Sendo necessário, dessa forma, uma apropriação mais contundente das competências citadas no modelo pelos gestores de campus, seja por vias individuais e/ou por iniciativa da rede ou de cada instituto federal, de forma individualizada, devendo uma análise mais aprofundada para essa situação.

Os autores Brito, Paiva e Leone (2012) ao investigarem o perfil de competências gerenciais das pessoas que estão a frente das organizações de ensino superior tecnológicas encontraram evidências e concluíram que o desenvolvimento profissional daqueles sujeitos é uma busca pessoal deles e as próprias organizações pouco contribuem, sendo que esses gestores desenvolvem suas competências no dia a dia do labor administrativo.

A figura 06 expõe a percepção dos sujeitos pesquisados sobre a estrutura de valores concorrentes na gestão que pode ser analisada como um resultado positivo ou negativo. Para Quinn et. al (2015) buscar ser um gerente-mestre não necessariamente o gestor deve ser ótimo em todas as competências do modelo, exige-se também um nível de tomada de decisão com mistura e equilíbrio no uso das diferentes variáveis dos quatro modelos de modo apropriado para cada situação.

Conforme a figura 06 entende-se que os diretores gerais estão no limiar de uma zona positiva para uma zona negativa do líder na estrutura de valores concorrentes. Isso significa que, no quadrante colaborar estão saindo de gestores orientados a processo e facilitadores de interação para diretores gerais muito democráticos e participativos, tornando a produtividade lenta; no quadrante criar os gestores se mostram caminhando para serem irrealistas, pouco práticos e desperdiçando energia; já nos fatores competir e controlar os diretores estão mais voltados para a zona positiva do líder na estrutura de valores concorrentes, por suas médias, em sua maioria, menores que 4,0 , podendo ser caracterizados pela orientação às tarefas, possuidores de iniciativas, direcionadores, fornecedores de estrutura, seguros, confiáveis, especialistas técnicos e coletores de informações.

\subsection{Analise Fatorial Exploratória e Confirmatória do modelo teórico}

O modelo teórico proposto por Quinn et al. (2015) é fruto de pesquisas e contribuições ao longo do tempo, tornou-se um construto consolidado em pesquisas organizacionais, porém, com sujeitos objetos de estudo dessa pesquisa, não se pode verificar estudos que demonstrassem e confirmassem as ideias do framework e a unidade de análise escolhida na proposta metodológica e teórica. No entanto, sabe-se a partir das proposições dos 
autores, como as variáveis se comportam e relacionam, quer dizer, a estrutura de fatores é conhecida. Nesse sentido tornou-se de fundamental importância analisar e testar se o modelo teórico confirmava as hipóteses especificas sobre as estruturas e relações entre as variáveis latentes (modelo de relações humanas, sistema aberto, meta racional e processo interno) e as variáveis observáveis (20 competências) subjacentes aos dados.

O primeiro procedimento realizado foi medir a adequação da amostra de kaiserMeyer-Olkin (KMO) e o teste de esfericidade de Bartllet, conforme dados especificados na tabela 13.

Tabela 13 - teste de KMO e Bartlett

\begin{tabular}{llr|r}
\hline & Domínio & \multicolumn{1}{c|}{$\begin{array}{c}\text { Frequência } \\
\text { de uso }\end{array}$} \\
\hline Medida Kaiser-Meyer-Olkin de adequação de amostragem & 0,927 & 0,921 \\
\hline Teste de esfericidade de Bartlett & Aprox. Qui-quadrado & 1778,650 & 1972,793 \\
\cline { 2 - 4 } & Graus de liberdade & 190 & 190 \\
\cline { 2 - 4 } & Significância & 0,000 & 0,000 \\
\hline
\end{tabular}

Fonte: elaborada pelo autor (2018), com base nos dados da pesquisa

A medida Kaiser-Meyer-Olkin $(0,927)$ para o nível de domínio e $(0,921)$ para frequência de uso, indica um grau excelente de ajuste dos dados a análise fatorial e o teste de Bartlett foi altamente significativo [ $\mathrm{X}^{2}(190)=1778,650, \mathrm{p}$ menor que 0,001$]$ para o nível de domínio e $\left[\mathrm{X}^{2}(190)=1972,793\right.$, p menor que 0,001] para frequência de uso; portanto, a realização da análise fatorial é apropriada, indicando, conforme Field (2009), que padrões de correlações são relativamente compactos.

Em seguida aplicou-se uma análise de componente principal com rotação Varimax aos 20 itens em análise, após a verificação da sua adequabilidade aos dados em questão, por via do teste de esfericidade de Bartlett da estatística de Kaiser-Meyer-Olkin (KMO), conforme tabela 14. 
Tabela 14 - matriz de componente rotativa* e comunalidades

\begin{tabular}{|c|c|c|c|c|c|c|}
\hline \multirow[b]{2}{*}{ Variáveis } & \multicolumn{4}{|c|}{ Componentes } & \multicolumn{2}{|c|}{ Comunalidades } \\
\hline & 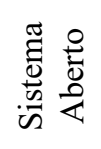 & 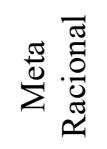 & 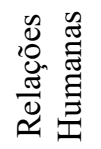 & 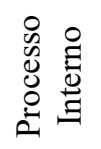 & . & 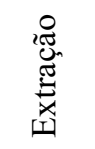 \\
\hline $\begin{array}{l}\text { 19. Negociar acordos e compromissos com as pessoas na } \\
\text { organização }\end{array}$ & ,652 &, 162 &, 160 & , 165 & 1,000 &, 505 \\
\hline $\begin{array}{l}\text { 13. Motivar a si mesmo e as outras pessoas no ambiente de } \\
\text { trabalho }\end{array}$ & ,650 &, 101 &, 275 & ,084 & 1,000 & ,515 \\
\hline $\begin{array}{l}\text { 16. Usar o poder com ética e efetividade no ambiente de } \\
\text { trabalho }\end{array}$ & ,640 &,- 031 & ,423 & ,069 & 1,000 & ,594 \\
\hline 17. Comunicar novas ideias no ambiente de trabalho & ,610 &, 165 & ,102 & ,376 & 1,000 & ,552 \\
\hline 20. Implantar e sustentar a mudança na organização &, 587 &, 374 &,- 021 & ,042 & 1,000 & ,487 \\
\hline $\begin{array}{l}\text { 18. Estimular e promover inovação no ambiente } \\
\text { organizacional }\end{array}$ &, 581 & ,336 &,- 049 & ,242 & 1,000 &, 511 \\
\hline $\begin{array}{l}\text { 5. Gerenciar e estimular o conflito construtivo e produtivo no } \\
\text { ambiente de trabalho }\end{array}$ & ,477 &, 250 &, 219 & ,281 & 1,000 & ,417 \\
\hline $\begin{array}{l}\text { 12. Estabelecer metas, objetivos, planos e estratégias } \\
\text { organizacionais }\end{array}$ & ,263 & ,702 & ,161 & ,093 & 1,000 & ,596 \\
\hline 14. Projetar a estrutura e organizar o trabalho na organização & ,248 &, 670 & 079 &, 159 & 1,000 &, 542 \\
\hline $\begin{array}{l}\text { 9. Medir e monitorar o desempenho e a qualidade dos } \\
\text { processos e resultados organizacionais }\end{array}$ &, 144 &, 653 &, 112 &, 314 & 1,000 &, 558 \\
\hline 6. Organizar os fluxos de informação na organização &,- 060 &, 613 & ,241 & ,278 & 1,000 &, 514 \\
\hline $\begin{array}{l}\text { 15. Gerenciar a execução das estratégias e buscar o alcance } \\
\text { efetivo dos resultados desejados da organização }\end{array}$ &, 428 &, 593 & ,198 &, 052 & 1,000 &, 577 \\
\hline $\begin{array}{l}\text { 11. Desenvolver e comunicar uma visão organizacional para } \\
\text { os funcionários }\end{array}$ &, 184 &, 503 & 417 &, 180 & 1,000 & ,493 \\
\hline $\begin{array}{l}\text { 10. Estimular e possibilitar que os funcionários e a própria } \\
\text { organização busquem a conformidade }\end{array}$ & ,441 & ,456 & 239 &,- 023 & 1,000 & ,459 \\
\hline $\begin{array}{l}\text { 4. Gerenciar grupos de trabalho e liderar equipes na } \\
\text { organização }\end{array}$ & ,375 & ,401 & ,399 &, 176 & 1,000 & ,491 \\
\hline $\begin{array}{l}\text { 1. Entender a si mesmo } \\
\text { organizacional }\end{array}$ & 075 &, 073 & ,692 & ,304 & 1,000 &, 582 \\
\hline $\begin{array}{l}\text { 2. Comunicar com honestidade e efetividade no ambiente de } \\
\text { trabalho }\end{array}$ & ,314 &, 225 & ,631 &,- 108 & 1,000 &, 559 \\
\hline 3. Orientar e desenvolver os funcionários da organização &, 145 & ,358 &, 614 &, 136 & 1,000 &, 544 \\
\hline 7. Trabalhar e gerenciar em equipes multifuncionais & 218 &, 257 & 185 & ,808 & 1,000 &, 801 \\
\hline \multirow[t]{2}{*}{ 8. Planejar e coordenar projetos } & ,283 & ,266 &, 122 &, 783 & 1,000 & ,780 \\
\hline & 17,50 & 17,07 & 10,87 & 9,93 & & \\
\hline
\end{tabular}

*Atributo selecionado para o fator da coluna

Método de Extração: Análise de Componente Principal

Método de Rotação: Varimax com Normalização de Kaiser

a. Rotação convergida em 9 iterações.

Fonte: elaborada pelo autor (2018), com base nos dados de pesquisa

A tabela 14 demonstra destaca cargas fatoriais com um valor absoluto maior que 0,4 pois Stevens (1992) recomenda que estudos com amostras acima de 200 e menores que 300 esse seja o número para que uma carga fatorial seja considerada significativa. Percebe-se pelos valores na tabela 14 que os 4 (quatro) fatores explicam quantias consideráveis das 
variâncias, permitindo a extração de 4 componentes (conforme framework) que explicam $55,38 \%$ da variância total, quando considerado o nível de domínio e, 57,00\% quando se refere ao nível de frequência de uso, equivalente ao factor loading após a rotação. Percebe-se ainda que os graus de comunalidades das variáveis estão próximos de 1, portanto, o modelo possui um poder relativo de explicação de cada variável, já que existem 5 (cinco) variáveis, tanto no nível de dominio quanto na frequência de uso, com valores de comunalidade um pouco abaixo do valor mínimo $(0,500)$ usualmente aceitável.

Analisando-se a tabela 14, a qual as suas variáveis estão ordenada pelo tamanho da carga fatorial, verifica-se que duas variáveis carregadas no fator "sistema aberto" são diferentes do modelo proposto por Quinn et.al (2015), são elas: competência "5. Gerenciar e estimular o conflito construtivo e produtivo no ambiente de trabalho" e competência "13. Motivar a si mesmo e as outras pessoas no ambiente de trabalho". O fator "sistema aberto" é relacionado diretamente ao aspecto da criação, da busca pela inovação, adaptação, crescimento e aquisição de recursos, nesse sentido os dados mostram que a competência 5 pode estimular a mudança na medida em que gestão do conflito seja de maneira produtiva. Já a competência 13 se alinha com essa perspectiva pois ela exige que cada uma das pessoas na organização dê o melhor de si, por consequência as pessoas motivadas, empoderadas e comprometidas são mais produtivas e podem criar mais.

O fator 4 , meta racional, na tabela 4 , revela 4 competências não associadas originalmente ao modelo, são elas: competência "9. Medir e monitorar o desempenho e a qualidade dos processos e resultados organizacionais", competência "6. Organizar os fluxos de informação na organização", competência “10. Estimular e possibilitar que os funcionários e a própria organização busquem a conformidade" e competência "4. Gerenciar grupos de trabalho e liderar equipes na organização". O componente meta racional está relacionado a competição, buscando melhorar a produtividade e aumentar a lucratividade, assim a competência 10 está, em um primeiro momento, destoante do contexto do fator, no entanto, pode-se afirmar que a busca pela conformidade em alto grau pode causar também perdas de oportunidade e que agir de acordo com uma solicitação ou regra são situações que podem se encaixar dentro do construto meta racional perfeitamente.

Analisando ainda a tabela 14 e o fator relações humanas e suas variáveis agregadas, nota-se que todas as três variáveis estão de acordo com o modelo proposto por Quinn et. al (2015), porém, as competências 4 e 5 não foram associadas ao fator relações humanas. Esse fator preconiza o desenvolvimento dos membros da organização quanto aos seus envolvimentos e comprometimentos, assim o(a) gestor(a) foca o interno organizacional e a flexibilidade. 
Já o fator processo interno foi o que obteve menos associações de variáveis, ficando somente as competências "7. Trabalhar e gerenciar em equipes multifuncionais" e "8. Planejar e coordenar projetos". Isso deixa claro que os dados obtidos na pesquisa evidenciam o que o modelo propõe, mas, destaca, também, que o controle organizacional visando a estabilidade e a continuidade são competências que devem ser melhor caracterizadas ou associadas a outros fatores, ficando o modelo com somente 3 fatores ou construtos, podendo gerar nomenclaturas, abrangências e conteúdos distintos do modelo original.

Para medir a confiabilidade interna do modelo (abordagem de valores concorrentes) foi calculado o alfa de Cronbach, conforme valores demonstrados na tabela 15.

Tabela 15 - teste de alfa de Cronbach

\begin{tabular}{c|c|c}
\hline Alfa de Cronbach & Alfa de Cronbach com base na padronização dos itens & $\begin{array}{c}\mathrm{N}^{\circ} \mathrm{de} \\
\text { itens }\end{array}$ \\
\hline 0,912 & 0,912 & 20 \\
\hline
\end{tabular}

Fonte: elaborada pelo autor (2018), com base nos dados da pesquisa

A tabela 15 evidencia a confiabilidade do instrumento refletindo o construto que está medindo. O valor para medir a consistência interna do instrumento foi de 0,912 , o que indica uma ótima consistência.

Continuando em busca de finalizar a análise fatorial confirmatória, foi necessário verificar as medidas de ajustes absolutos, medidas de ajuste incremental e os índices de ajustes parcimonioso, conforme resultados demonstrados na tabela 16.

\begin{tabular}{lcc}
\hline \multicolumn{3}{c}{ Tabela 16 - medidas de ajuste geral do modelo } \\
\hline \multirow{3}{*}{ Mjuste absoluto } & GFI & Valor \\
& $\chi 2$ & 312,030 \\
Ajuste incremental & RMSEA & 0,061 \\
Ajuste parcimonioso & TLI & 0,896 \\
\end{tabular}

Fonte: elaborada pelo autor (2018), com base nos dados da pesquisa

Com base nos resultados encontrados e evidenciados na tabela 16, percebe-se o grau de ajuste do modelo abordagem de valores concorrentes, na medida em que o índice de qualidade do ajuste (GFI) foi de 0,880 , valor próximo a 1 , indicando um ajuste. Já o valor do Qui-quadrado $(\chi 2)$, ficou 312,036, com um grau de liberdade de 164. A Raiz do erro quadrático médio de aproximação (RMSEA), resultou em 0,061, ficando abaixo de 0,08, valor aceitável para o parâmetro. Enquanto o índice de Tuker-Lewis (TLI) atingiu 0,896, onde o valor de 1 seria um ajuste perfeito e acima de 0,90 o recomendável, não atingiu, porém ficou 
bastante próximo do índice ideal. E, por fim, dentro da categoria do ajuste parcimonioso, temo um valor de 0,910 para o índice de ajuste comparativo (CFI), que é um valor considerado próximo ao ajuste perfeito.

Portanto, seguindo as recomendações e referências estatísticas de Vidal (2016), Lopes (2005) e Field (2013), encerra-se a análise fatorial exploratória e confirmatória do framework abordagem de valores concorrentes na gestão de Quinn et. al (2015). 


\section{CONCLUSÃO}

Depois de apresentados, analisados e discutidos os dados obtidos na pesquisa, busca-se conclusões e respostas para a indagação inicial do estudo: como se configura o perfil de competências gerenciais de gestores de instituições federais de educação brasileiras à luz do modelo da abordagem de valores concorrentes na gestão de Quinn et al. (2015)? Com o objetivo de descrever essa configuração sobre o perfil de competências gerenciais desses sujeitos e unidade de análise a pesquisa evidenciou que há uma convergência preponderante no perfil dos gestores para o modelo de relações humanas no nível de frequência de uso e no nível de domínio a tendência se volta para o modelo de sistema aberto. Portanto, os gestores de campi dos institutos federais de educação usam mais frequentemente as competências que buscam criar e sustentar o compromisso e a coesão, onde os gestores se direcionam para o desenvolvimento de recursos humanos; e dominam mais as competências associadas ao modelo de sistema aberto, orientados para a expansão e mudança, buscam efetivamente se adaptarem às mudanças e adquirirem suporte externo. É importante sublinhar como resultado que o perfil de competências gerenciais dos gestores, em todas as dimensões, é mais alto no nível de frequência de uso comparado ao domínio das competências, nesse sentido, os gestores usam as competências no dia a dia de suas atividades, porém, não demonstram capacidade conceitual e prática sobre as mesmas em igual proporção, existindo um hiato considerável de percepção de diferenças.

$\mathrm{Na}$ dimensão relações humanas os escores obtidos na competência gerencial comunicar com honestidade e efetividade no ambiente de trabalho foram os maiores, indicado que o gestor, além de perceberem a necessidade de uso, eles também deixaram dados conclusivos de que dominam aquela competência em comparação as demais do modelo. Nesse sentido os gestores estão mais voltados para um processo de comunicação aberta e respeitosa por parte de todos. Em direção oposta a competência que trata sobre gerenciamento de conflitos de maneira produtiva não foi bem avaliada pelos gestores quanto aos seus níveis de domínio e frequência de uso no exercício da função. Portanto, a referida competência não faz parte das que obtiveram significância positiva para enquadrar o perfil especificamente nesse fator.

Para o modelo de processo interno o perfil dos sujeitos tende a ser caracterizado de maneira efetiva para o eixo da competência que busca estimular e possibilitar que os funcionários e a própria organização cumpram as regras; e a competência medir e monitora o desempenho é a de menor valor para compor o perfil dos gestores de instituições federais de 
educação.

Dentre as características obtidas no modelo de meta racional os diretores gerais de campi são descritos como sujeitos que tendem mais predominantemente motivar a sim mesmo e as outras pessoas no ambiente organizacional, mas não são favoráveis a gerenciar as execuções das estratégias e nem buscar o alcance efetivo dos resultados desejados dos If's, saindo das características de seus perfis.

Já quando o foco é o modelo de sistema aberto os gestores se percebem com muito mais domínio e com necessidade de uso da competência que busca utilizar o poder com ética e efetividade no ambiente de trabalho, porém não tendem a ter um perfil que estimule e promova a inovação no contexto dos institutos federais.

A valorização e o distanciamento, em termos de resultado de médias de determinadas competências dentre os fatores do modelo pode ser representativa de um perfil que está em zona positiva, voltado a criação, quanto ao seu nível de domínio e voltado para a colaboração quanto a frequência de uso das competências, sendo um líder caracterizado que mostra consideração, orientado a processos, criativo, visualiza a mudança e politicamente astuto.

O perfil de competências gerenciais dos gestores de campi dos institutos federais medido pela abordagem de valores concorrentes obteve médias altas, o que pode ser constatado pelos resultados, indicando um nível de concordância em praticamente todas as práticas administrativas delimitadas pelo modelo, pode-se, dessa forma, concluir que o construto é eficiente para analisar o perfil de competências de gestores públicos de instituições federais de educação, ciência e tecnologia. Destaca-se as evidências que demonstram a validade teórica no que se refere a compreensão e a representatividade dos itens do instrumento.

O caminho percorrido durante a análise fatorial exploratória e confirmatória demonstra a segurança estatística, a validade e a confiabilidade do framework adotado nesta pesquisa, confirmando as hipóteses especificas sobre as estruturas e relações entre as variáveis latentes (modelo de relações humanas, sistema aberto, meta racional e processo interno) e as variáveis observáveis (20 competências) subjacentes aos dados, já que a medida KaiserMeyer-Olkin indicou um grau excelente de ajuste dos dados a análise fatorial e o teste de Bartlett foi altamente significativo, sendo que os 4 (quatro) fatores explicam quantias relativamente grandes das variâncias, permitindo a extração de 4 componentes (conforme framework) que explicam a maior parte da variância total. A análise fatorial do modelo também demonstrou evidencia da confiabilidade do instrumento refletindo o construto que 
está medindo, assim os resultados apontaram para uma ótima consistência interna do instrumento e o diagrama de caminho especificou o modelo fatorado, permitindo uma sólida relação entre as variáveis, percebe-se também, nitidamente, um alto grau de ajuste do modelo.

Na análise da configuração do perfil de competências gerenciais dos ocupantes da função de direção geral de campus dos institutos federais se conclui que, quanto ao nível de domínio, os dados demonstraram uma tendência, em valores absolutos, para a dimensão sistema aberto, em busca de ações criativas. Analisando, de maneira geral, as percepções dos gestores pesquisados quanto ao nível de frequência de uso das competências, aqueles se mostraram mais vinculados ao modelo de relações humanas, focados na atividade colaborativa no ambiente organizacional.

Ao se realizar a análise de componente principal com a rotação varimax das 20 variáveis em análise o modelo tomou uma configuração diferente da proposta original de Quinn et. al (2015), ficando assim distribuídos os fatores e suas respectivas competências:

Sistema aberto: negociar acordos e compromissos com as pessoas na organização; motivar a si mesmo e as outras pessoas no ambiente de trabalho; usar o poder com ética e efetividade no ambiente de trabalho; comunicar novas ideias no ambiente de trabalho; implantar e sustentar a mudança na organização; estimular e promover inovação no ambiente organizacional; e gerenciar e estimular o conflito construtivo e produtivo no ambiente de trabalho.

Meta racional: estabelecer metas, objetivos, planos e estratégias organizacionais; projetar a estrutura e organizar o trabalho na organização; medir e monitorar o desempenho e a qualidade dos processos e resultados organizacionais; organizar os fluxos de informação na organização; gerenciar a execução das estratégias e buscar o alcance efetivo dos resultados desejados da organização; desenvolver e comunicar uma visão organizacional para os funcionários; estimular e possibilitar que os funcionários e a própria organização busquem a conformidade; e gerenciar grupos de trabalho e liderar equipes na organização.

Relações humanas: entender a si mesmo e os outros no ambiente organizacional; comunicar com honestidade e efetividade no ambiente de trabalho; e orientar e desenvolver os funcionários da organização.

Processo interno: trabalhar e gerenciar em equipes multifuncionais; e planejar e coordenar projetos.

É importante destacar que a abordagem de valores concorrentes na gestão, modelo proposto e aprimorando ao longo dos anos por Quinn et. al (2015) estimulam a reflexão ativa, busca intensa por aprimoramento e mudança de lógica de pensamento no processo de tomada de decisão no ambiente organizacional. Nesse contexto o framework propõe estimular o 
gestor a desenvolver uma estratégia ampla que possa dominar a fundo para implantar e monitorar no futuro, sendo necessária uma auto avaliação para cada competência quanto ao que se sabe sobre seu desempenho atual, como ele poderia ser mais efetivo, quais pessoas poderiam servir como exemplo, quais cursos deveria realizar, livros importantes, quais objetivos e prazos o gestor deveria determinar, com que ele deveria compartilhar os seus resultados e como avaliará seus esforços para cumprir com o que o modelo pede. Cumprindo essas exigências, a partir dessa avaliação, a organização e o próprio gestor caminhariam para um desenvolvimento eficaz.

O modelo, no entanto, poderia esmiuçar um pouco mais as dimensões e demonstrar com mais evidências e práticas administrativas em forma de competências. Isso se deve ao fato que uma competência pode está tentando resumir muitas atividades, conhecimentos e habilidades necessárias ao líder gerencial em uma única variável do modelo, o que pode ser generalista e ao mesmo tempo ser vago e confuso para o entendimento e o desenvolvimento das referidas competências elencadas. Nesse sentido sugere-se a necessidade de pesquisas aprofundadas que busque o aprimoramento das competências chave da abordagem de valores concorrentes e a transforme em uma escala psicométrica com o objetivo de se construir uma ferramenta capaz de mensurar as percepções de gestores em diferentes tipos de organizações quanto a importância do uso de cada competência, assim como o nível de domínio daquelas para os gestores. Assim, torna-se importante que futuras pesquisas tenham como objetivo diagnosticar as competências gerenciais básicas e necessárias ao desenvolvimento de funções estratégicas em organizações públicas de ensino, em especial nos institutos federais de educação e, consequentemente propor programas de desenvolvimento para gestores com bases nessas competências gerenciais.

A pesquisa respondeu satisfatoriamente ao alcance dos objetivos propostos. Porém, pode-se inferir que, por se tratar de um estudo eminentemente descritivo carece de aprofundamento qualitativo em busca de entendimentos mais específicos sobre a função, sobre o contexto de cada unidade. É recomendável o complemento dos achados aqui encontrados com outras pesquisas que visem incluir outras populações, outros sujeitos, outros tipos de organizações, metodologias que empreguem uma abordagem diferente. Uma proposta viável seria entender na percepção dos sujeitos gestores e não gestores as competências inerentes a cada função gerencial e como a falta ou não desses atributos podem ocasionar resultados negativos para os diversos tipos de organizações.

Quanto a outras limitações, fica evidente que um questionário auto administrado como o aplicado na pesquisa pode não refletir de maneira satisfatória as subjetividades dos 
sujeitos enquanto detentores ou não de determinadas competências ou suas usabilidades no cotidiano da função gerencial, assim, importante seria um aprofundamento maior nessa questão. Outra situação que poderia limitar os achados aqui encontrados refere-se a não observação in loco das ações gerenciais dos sujeitos, uma observação participante e até mesmo uma metodologia diferente, como um estudo multicaso e utilizando o grupo focal poderiam evidenciar de maneira a entender melhor as competências gerenciais mais usadas e dominadas pelos gestores no dia a dia de suas funções. 


\section{REFERÊNCIAS}

AMARAL, Helena Kerr do. Desenvolvimento de competências de servidores na administração pública brasileira. Revista do Serviço Público, v. 57, n. 4, p. 549-563, Out./Dez., 2006.

ANTONACOPOULOU, Elena P.; FITZGERALD, Louise. Reframing competency in management development. Human Resource Management Journal, v. 6, n. 1, p. 27-48, 1996.

ARMSTRONG, Michae; TAYLOR, Stephen. Armstrong's handbook of human resource management practice. 13. ed. London: KoganPage, 2014.

BABBIE, Earl. Métodos de pesquisa de survey. 3. Ed. Belo Horizonte: UFMG, 2005.

BAISCH, Lindiane da Veiga et al. Gestão estratégica e as competências gerenciais no departamento de marketing: estudo de uma indústria de bebidas. Revista de Administração da UFSM, v. 5, edição especial, p. 729-748, dez., 2012.

BARROS, Conceição de Maria Pinheiro et al. As competências gerenciais desenvolvidas pelos secretários executivos. Revista de Gestão e Secretariado - GeSec, v. 4, n. 2, p. 25-47, /dez., 2013.

BITENCOURT, Claudia Cristina. A gestão de competências gerenciais e a contribuição da aprendizagem organizacional. RAE - Revista de Administração de Empresas, v. 44, n. 1, p. 58-69, Jan/Mar, 2004.

BITENCOURT, Claudia Cristina. A gestão de competências gerenciais e a contribuição da aprendizagem organizacional - a experiência de três empresas australianas. RAM - Revista de Administração Mackenzie, v. 3, n. 1, p. 135-157, 2002.

BOWMAN, James S.; WEST, Jonathan P.; BECK, Marcia A. Achieving competencies in public service: the professional edge. 2. ed. New York: Sharpe, 2010.

BOYATZIS, Richard E. The competent manager: a model for effective performance. New York: John Wiley \& Sons, 1982.

BOYATZIS, Richard E. Competencies in the 21 st century. Journal of Management Development, v. 27, n. 1, p. 5-12, 2008.

BRANDÃO, Hugo Pena. Aprendizagem, contexto, competência e desempenho: um estudo multinível. Tese (Doutorado em Psicologia Social, do Trabalho e das Organizações) Universidade de Brasília, 2009.

BRANDÃO, Hugo Pena; BORGES-ANDRADE, Jairo Eduardo; GUIMARÃES, Tomás de Aquino. Desempenho organizacional e suas relações com competências gerenciais, suporte organizacional e treinamento. Revista de Administração, v. 47, n. 4, p. 523-539, Out./Nov./Dez., 2012.

BRANS, M.; HONDEGHEM, A. Competency Frameworks in the Belgian Governments: Causes, Construction and Contents. Public Administration, v.83, n.4, p. 823-837, 2005. 
BRASIL. Lei n. 11.892, de 29 de dezembro de 2008. Institui a Rede Federal de Educação Profissional, Científica e Tecnológica, cria os Institutos Federais de Educação, Ciência e Tecnologia, e dá outras providências. Diário Oficial da União, Poder Executivo, Brasília, DF, 30 dez. 2008a. p.1.

BRITO, Lydia Maria Pinto; LEONE, Nilda Maria de Clodoaldo Guerra Pinto. Competências gerenciais requeridas em empresas familiares: um olhar feminino. Revista de Ciências da Administração, v. 14, n. 32, p. 50-64, 2012.

BRITO, Lydia Maria Pinto; PAIVA, Ionara Cortez Bezerra de; LEONE, Nilda Maria de Clodoaldo Guerra Pinto. Perfil de competências gerenciais no Ensino Superior Tecnológico.

Revista Ciências Administrativas, v. 18, n. 1, p. 189-216, Jan./Jun., 2012.

BÜNDCHEN, Edson; ROSSETTO, Carlos Ricardo; SILVA, Anielson Barbosa. Competências gerenciais em ação: o caso do Banco do Brasil. REAd - Revista Eletrônica de Administração, v. 69, n. 2, p. 396-423, Mai./Ago., 2011.

CAPUANO, Ethel Airton. Gestão por competências no setor público: experiências de países avançados e lições para o Brasil. Revista do Serviço Público, v. 66, n. 3, p. 371-394, Jul./Set., 2015.

CARVALHO, Ana Carolina Vilela de; STEFANO, Silvio Roberto; MUNCK, Luciano. Competências voltadas à sustentabilidade organizacional: um estudo de caso em uma indústria exportadora. Gestão e Regionalidade, v. 31, n. 91, p. 33-48, jan./abr., 2015.

CEITIL, Mário (Org.). Gestão e desenvolvimento de competências. Lisboa: Sílabo, 2007.

COOPER, Donald R.; SCHINDLER, Pamela S. Métodos de pesquisa em Administração. 10. ed. Porto Alegre: Bookman, 2011.

COTRIM FILHO, Valdir Valdivino; FARIAS, Josivania Silva. Competências relevantes ao papel ocupacional de gerência em nível operacional em um órgão da administração pública federal do Brasil. Revista Eletrônica de Gestão Organizacional, v. 11, n. 2, p. 422-185, Mai./Ago., 2013.

CRESWELL, J. W. Projeto de pesquisa: métodos qualitativo, quantitativo e misto. 3. ed. Porto Alegre: Artmed, 2010.

DIAS, Helane Cristine Vianna Barbosa; PAIVA, Kely César Martins de. Formação de competências gerenciais a partir de disciplinas de gestão no curso de Enfermagem: percepções de alunos de uma universidade privada. REME - Revista Mineira de Enfermagem, v. 13, n. 4, p. 474-484, /dez., 2009.

DIAS, Helaine Cristine; PAIVA, Kely César Martins de. Competências do enfermeiro: estudo em um hospital privado. Revista Brasileira de Enfermagem, v. 64, n. 3, p. 511-520, /jun., 2011.

DUTRA, Joel Souza. Competências: conceitos e instrumentos para a gestão de pessoas na empresa moderna. São Paulo: Atlas, 2013.

DUTRA, Joel Souza; FLEURY, Maria Tereza Leme; RUAS, Roberto. (Orgs.).

Competências: conceitos, métodos e experiências. São Paulo: Atlas, 2008. 
ÉSTHER, Angelo Brigato. As competências gerenciais dos reitores de universidades federais em Minas Gerais: a visão da alta administração. Cadernos EBAPE.BR, v.9, Edição especial, Rio de Janeiro, Jul. 2011, p.648-667.

FAERMAN, Sue R. et al. Bridging management practice and theory. Public Administration Review, v. 47, n. 4, p. jul./ago., p. 310-319, 1987.

FÉLIX, Cléa Mara Reis. A prática de competências gerenciais no setor público. RAP Revista de Administração Pública, v. 39, n. 2, p. 255-278, mar./abr., 2005.

FERIGOTTI, Cristina; FERNANDES, Bruno. Competências Gerenciais E Capacidade Para Inovação: O Caso Da Electrolux Do Brasil S/a. RAI - Revista de Administração e Inovação, v. 11, n. 1, p. 73-96, jan./mar., 2014.

FERREIRA, Patricia Itala. Gestão por competências. Rio de Janeiro: LTC, 2015.

FIELD, Andy. Descobrindo a estatística usando SPSS. 2. ed. Porto Alegre: Artmed, 2009.

FLECK, Carolina Freddo; PEREIRA, Breno Augusto Diniz. Professores e Gestores: análise do perfil das competências gerenciais dos coordenadores de pós-graduação das instituições federais de ensino superior (IFES) do RS, Brasil. Organizações e Sociedade - O\&S, v. 18, n. 57, p. 285-301, 2011.

FLEURY, Maria Tereza Leme; FLEURY, Afonso. Construindo o conceito de competência. Revista de Administração Contemporânea, v. 5, n. Edição Especial, p. 183-196, 2001.

FREITAS, Dante Bonetti de. Papéis e competências do líder: um estudo em organização multinacional francesa. Dissertação (Mestrado em Administração de empresas) - Pontifícia Universidade Católica de São Paulo, São Paulo, 2007.

FREITAS, Pablo Fernando Pessoa de. Relações entre competências gerenciais de líderes de grupos de pesquisa e resultados alcançados. Dissertação (Mestrado em Administração) Universidade de Brasília. Brasília, 2016.

GLÓRIA JUNIOR, Odair de Souza; ZOUAIN, Deborah Moraes; ALMEIDA, Gustavo de Oliveira. Competências e Habilidades Relevantes para um Chefe de Unidade Descentralizada de Perícia da Polícia Federal. RAM - Revista de Administração Mackenzie, v. 15, n. 4, p. 15-46, jul./ago., 2014.

GODOY, Arilda Schmidt; D’AMELLO, Marcia. Competências gerenciais desenvolvidas por profissionais de diferentes formações. Organizações e Sociedade - O\&S, v. 19, n. 63, p. 621-639, Out./Dez., 2012.

GUIMARÃES, Tomas de Aquino. A nova administração pública e a abordagem da competência. RAP - Revista de Administração Pública, v. 34, n. 3, p. 125-140, Maio/Jun, 2000 .

HAIR JR., Joseph F. et al. Fundamentos de métodos de pesquisa em administração. Porto Alegre: Bookman, 2005.

HAMEL, Gary. PRAHALAD, C. K. Competindo pelo futuro: estratégias inovadoras para obter o controle do seu setor e criar os mercados de amanhã. Rio de Janeiro: Campus, 1995. 
HAVE, Steven ten et al. Key management models: the management tools and practices that will improve your business. London: Pearson, 2003.

HONDEGHEM, Annie; HORTON, Sylvia; SCHEEPERS, Sarab. Modelos de gestão por competências na Europa. Revista do Serviço Público, v. 57, n. 2, p. 241-258, Abr/Jun, 2006.

HORNG, J. S. et al. Competency Analysis of Top Managers in the Taiwanese Hotel Industry. International Journal of Hospitality Management, v.30, p.1044-1054, 2011.

KANAANE, Roberto; FIEL FILHO, Alécio; FERREIRA, Maria das Graças. Gestão pública: planejamento, processos, sistemas de informação e pessoas. São Paulo: Atlas, 2010.

KENSKI, Julia Moreira; BRUNSTEIN, Janette. Limites e possbilidades do E-learning no desenvolvimento de competências gerenciais. REAd - Revista Eletrônica de Administração, v. 16, n. 67, p. 685-715, set./dez., 2010.

LAWLER, E.E. From Job-Based to Competency-Based Organizations. Journal of Organizational Behavior, V.15, n.1, p. 3-15, 1994.

LAWRENCE, Katherine A.; LENK, Peter; QUINN, Robert E. Behavioral complexity in leadership: The psychometric properties of a new instrument to measure behavioral repertoire. Leadership Quarterly, v. 20, n. 2, p. 87-102, 2009.

LE BOTERF, Guy. Desenvolvendo a competência dos profissionais. 3. ed. Porto Alegre: Artmed, 2003.

LIMA, Reginaldo de Jesus Carvalho; ARAGÃO, Silvano; GUIMARÃES, Eloísa Helena Rodrigues. Competências gerenciais em gestão de projetos: estudo em grandes empresas do stor da construção civil, em Minas Gerais. Revista de Gestão e Projetos - GeP, v. 7, n. 2, p. 42-53, Mai./Ago., 2016.

LOPES, Humberto Elias Garcia. Abrindo a caixa preta: considerações sobre a utilização da Análise Fatorial Confirmatória nas pesquisas em Administração. Revista Economia \& Gestão, v. 5, n. 11, p. 19-34, dez., 2005.

LOPES, Maurício Capobianco et al. Análise da relação entre aptidões cerebrais e competências gerenciais: o caso de uma empresa têxtil. Gestão \& Produção, v. 17, n. 1, p. 123-136, 2010.

LOUFRANI-FEDIDA, Sabrina. La gestion des ressources humaines au service de l'articulation entre management des compétences et organisation par projets. Revue de gestion des ressources humaines, v. 79, n. 1, p. 24, 2011.

LOWEN, Ingrid Margareth Voth et al. Competências gerenciais dos enfermeiros na ampliação da Estratégia Saúde da Família. Revista da Escola de Enfermagem USP, v. 49, n. 6, p. 967973, 2015.

MARRA, Adriana Ventola; MELO, Marlene Catarina de Oliveira Lopes. A prática social de gerentes universitários em uma instituição pública. Revista de Administração

Contemporânea, v. 9, n. 3, p. 9-31, 2005. 
MATIAS-PEREIRA, José. Manual de gestão pública contemporânea. 4. ed. São Paulo: Atlas, 2012.

MAY, Tim. Pesquisa social: questões, métodos e processos. 3.ed. Porto Alegre: Artmed, 2004.

MCCLELLAND, D C. Testing for competence rather than for intelligence. The American psychologist, v. 28, n. 1, p. 1-14, 1973.

MELO, Rosa Cândida; SILVA, Maria Júlia; PARREIRA, Pedro. Effective Leadership: Competing Values Framework. Procedia Technology, v. 16, p. 921-928, 2014.

MORAES, Valéria Vieira de; BORGES-ANDRADE, Jairo Eduardo; QUEIROGA, Fabiana. Construção e validação de medida para diagnóstico de competências relativas às funções de prefeito(a) e secretário(a) municipal. RAP - Revista de Administração Pública, v. 45, n. 5, p. 1445-1461, 2011.

MORASSUTTI, Alice Puperi Müller; GRISCI, Carmem Ligia Iochins. Competências gerenciais em tempos de reestruturação do trabalho bancário: o caso Caixa. REAd - Revista Eletrônica de Administração, v. 8, n. 2, p. 1-21, mar./abr., 2002.

MOURA, Maria Cristina Canovas de; BITENCOURT, Claudia Cristina. A articulação entre estratégia e o desenvolvimento de competências gerenciais. RAE - Revista de Administração de Empresas, v. 5, n. 1, jan./jun., 2006.

NEAGU, Associate Olimpia et al. A comparative analysis of managerial competencies based on evidence from Satu Mare County, Romania. Economics Series, v. 24, n. 4, p. 38-52, 2015.

NISEMBAUM, Hugo. A competência essencial. São Paulo: Editora Infinito, 2000.

NÓBREGA, Annamaria Barbosa do Nascimento et al. Competências gerenciais do nutiriconista gestor de unidades de alimentação terceirizada. Revista Eletrônica do Mestrado Profissional em Administração da Universidade Potiguar - RAUnP, v. 4, n. 2, p. 49-60, /set., 2012.

NUNES, F.; MARTINS, L.; DUARTE, H. Competency Management in EU Public Administrations. Survey commissioned by the Portuguese EU-Presidency, EUPAN Human Resources Working Group, 2007.

OLIVEIRA, Fátima Bayma de; SANT’ANNA, Anderson de Souza; VAZ, Samir Lofti. Liderança no contexto da nova administração pública: uma análise sob a perspectiva de gestores públicos de Minas Gerais e Rio de Janeiro. RAP - Revista de Administração Pública, v. 44, n. 6, p. 1453-1475, Nov/Dez, 2010.

OLIVEIRA, Patricia Whebber Souza; LIMA, Maria Dulcilene de. Competências e função gerencial: desvendando o Gap (lacuna) de competências de gestores públicos do núcleo de educação de uma niversidade federal brasileira. Revista Gestão Universitária na América Latina (GUAL), v. 6, n. 3, p. 44-60, set., 2013. 
PAIVA, Kely Cesar Martins; FERREIRA, Leandro dos Santos. Competências Gerenciais na área de Tecnologia de Informação: um estudo com gestores de empresas localizadas no Triângulo Mineiro. Revista Gestão \& Tecnologia, v. 13, n. 1, p. 205-229, /abr., 2013.

PAIVA, Kely; SANTOS, Andreia; LACERDA, Mario. Competências gerenciais e sua gestão na hotelaria: um estudo com gestores brasileiros. Tourism \& Management Studies, v. 10, n. 2, p. 84-93, 2014.

PARUMASUR, Sanjana Brijball; GOVENDER, Patsy. Managerial competencies as critical ingredients for a total quality management (TQM) initiative: Perceptions of managers in a KZN public sector division. SA Journal of Industrial Psychology, v. 35, n. 1, p. 153-165, 2009.

PASQUALI, L. (Org.). Análise fatorial para pesquisadores. Brasília: LabPAM Saber e Tecnologia, 2010.

PELISSARI, Anderson Soncini; GONZALEZ, Inayara Valéria Defreitas Pedroso; VANALLE, Rosângela Maria. Competências Gerenciais: Um Estudo Em Pequenas Empresas De Confecções. REAd - Revista Eletrônica de Administração, v. 17, n. 68, p. 149-180, jan./abr., 2011.

PENA, Felipe Gouvêa et al. "Hoje, líder de turma. Amanhã, líder organizacional”: um estudo sobre a oportunidade de desenvolvimento de competências aos graduandos em Administração. TPA - Teoria e Prática em Administração, v. 5, n. 1, p. 204-238, 2015.

PEREIRA, Aline Lucena Costa; SILVA, Anielson Barbosa da. As competências gerenciais nas instituições federais de educação superior. Cadernos EBAPE.BR, v. 9, Edição Especial, p. 627-647, Jul., 2011.

PEREIRA, Rafael Morais; MARQUES, Humberto Rodrigues; CASTRO, Fernando Luiz de; FERREIRA, Marco Aurélio Marques. Funções de confiança na gestão universitária: a dinâmica dos professores-gestores na Universidade Federal de Viçosa. Revista Gestão Universitária na América Latina - GUAL, v. 8, n. 1, p. 260-281, jan., 2015.

PICCHIAI, Djair. Competências gerenciais: estudo de caso de um hospital público. Cadernos de Gestão Pública e Cidadania, v. 13, n. 52, p. 19-41, /jun., 2008.

PIMENTA, Solange Maria; BRASIL, Elvécio Ribeiro. Gestores e competências organizacionais no terceiro setor em Itabira - MG. Gestão e Regionalidade, v. 22, n. 64, p. 78-89, /ago., 2006.

PINTO, José Larri de F. et al. Competências Gerenciais: Um Estudo Exploratório Em Uma Rede Do Comércio Varejista. Revista Global Manager, v. 14, n. 2, p. 23-38, 2014.

PIRES, Ana Paula Ivo. Competências Profissionais, práticas e políticas Organizacionais. Dissertação (Mestrado em Administração) - Universidade Federal da Bahia, Salvador, 2011.

PRAHALAD, C. K.; HAMEL, Gary. The Core Competence of the Corporation. Harvard Business Review, v. 68, n. 3, p. 79-91, 1990.

QUINN, Robert E. et al. Competências gerenciais: a abordagem de valores concorrentes na gestão. 6. ed. Rio de Janeiro: Elsevier, 2015. 
QUINN, Robert E. et al. Competências gerenciais: princípios e aplicações. Rio de Janeiro: Elsevier, 2003.

QUINN, Robert E. Beyond rational management: mastering the paradoxes and competing demands of high performance. Jossey-Bass, 1988.

RESENDE, Enio. O livro das competências: desenvolvimento das competências - a melhor auto-ajuda para pessoas, organizações e sociedade. Rio de Janeiro: Qualitymark Editora, 2000 .

RUAS, Roberto Lima. A atividade gerencial no século XXI e a formação de gestores: alguns nexos pouco explorados. REAd - Revista Eletrônica de Administração, v. 6, n. 3, p. 1-8, 2000 .

RUAS, Roberto Lima. Gestão por competências: uma contribuição à estratégia das organizações. In: RUAS, Roberto Lima, ANTONELLO, Claudia Simone, BOFF, Luiz Henrique (org.). Os novos horizontes da gestão: aprendizagem organizacional e competências. Porto Alegre: Bookman, 2005.

SAMPIERI, R. H.; COLLADO, C. F.; LUCIO, P. B. Metodologia de pesquisa. 5. ed. São Paulo: McGraw-Hll, 2013.

SANDBERG, J. Human competence at Work. Sweden: Frafikerna I Kungälv AB, 1996.

SANTOS, Isabel Cristina dos; VIAGI, Arcione Ferreira. Competências gerenciais em ambinte de rápidas mudanças. Revista Brasileira de Gestão e Desenvolvimento Regional - G\&DR, v. 1, n. 1, p. 84-99, jan./abr., 2005.

SEABRA, Andresa Lopes Cordeiro. Competências gerenciais de coordenadores de curso de graduação em Enfermagem em Belo Horizonte. Dissertação (Mestrado em Administração) - Faculdade Novos Horizontes, Belo Horizonte, 2014.

SEABRA, Andresa Lopes Cordeiro; PAIVA, Kely César Martins; LUZ, Talita Ribeiro da. Managerial competences of coordinators of undergraduate nursing courses. Revista Brasileira de Enfermagem, v. 68, n. 5, p. 608-616, /out., 2015.

SEATE, Barbara M; POOE, Raborale I D; CHINOMONA, Richard. Seate The relative importance of managerial competencies for predicting the perceived job performance of Broad-Based Black Economic Empowerment verification practitioners. SA Journal of Human Resource Management, v. 14, n. 1, 2016.

SILVA, Wânia Candida da. As competências gerenciais na percepção dos gestores dos hospitais públicos de Belo Horizonte. Dissertação (Mestrado em Administração) Universidade Federal de Viçosa, Viçosa - MG, 2012.

SOUSA, Adriana de Faria; VALADÃO JÚNIOR, Valdir Machado. Competências gerenciais no contexto internacional: possíveis contribuições de cursos superiores brasileiros de Administração. Organizações \& Sociedade (O\&S), v. 20, n. 66, p. 381-402, 2013.

SPENCER JR., Lyle M.; SPENCER, Signe M. Competence at work: models for superior performance. New York: John Wiley \& Sons, 1993. 
TRIOLA, Mario F. Introdução à estatística: atualização da tecnologia. Rio de Janeiro: LTC, 2013.

VAISHYA, Rashmi; JHA, Sumi; SRIVASTAVA, D. K. Revisiting Managerial CompetenciesLiterature Review. International Journal of Innovative Research \& Development, v. 5, n. 4, p. 328-338, 2016.

VIDAL, Dimas Ferreira. Análise fatorial em administração: uma aplicação prática com o software spss. Revista Eletrônica Estácio Papirus, v. 3, n. 1, p. 54-79, jan./jun., 2016.

VILKINAS, Tricia. The gender factor in management: how significant others perceive effectiveness. Women in Management Review, v. 15, n. 5/6, p. 261-272, 2000.

ZARIFIAN, Philippe. Objetivo competência: por uma nova lógica. São Paulo: Atlas, 2001. 


\section{APÊNDICE}

\section{APÊNDICE A - MATRIZ DE AVALIÇÃO DE COMPETÊNCIAS (DIREÇÃO GERAL)}

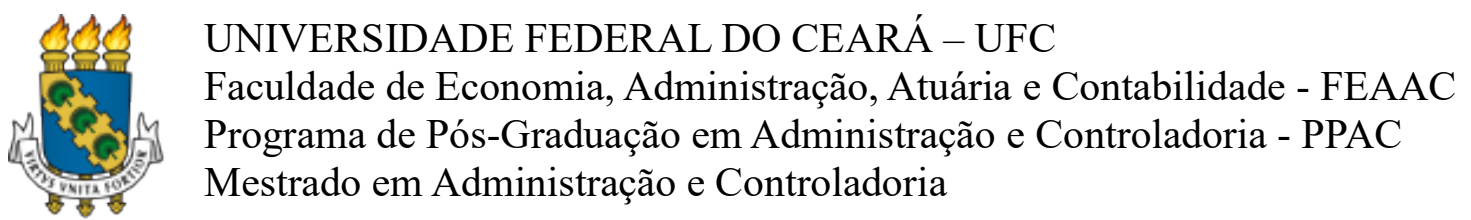

\section{APRESENTAÇÃO}

Senhor(a) Diretor(a),

Meu nome é Francis Fernandes, sou professor do eixo de Gestão e Negócios do Instituto Federal do Piauí, campus Angical do Piauí.

Venho convidá-lo(a) a participar desta pesquisa e contribuir com a construção de uma base de dados referentes a um projeto de dissertação, que visa obter o título de Mestre em Administração e Controladoria, realizado pelo Programa de Pós-Graduação em Administração e Controladoria da Universidade Federal do Ceará, sob a orientação do professor Dr. Augusto Cézar de Aquino Cabral.

A presente pesquisa tem o objetivo de investigar a configuração do perfil de competências gerenciais nos Institutos Federais de Educação, Ciência e Tecnologia do Brasil, conforme a abordagem de valores concorrentes proposta por Quinn et al. (2015)

$\mathrm{Na}$ primeira parte da pesquisa você estará respondendo a questões de caráter sociodemográfico, logo em seguida responderá as questões relacionadas à importância e a prática de competências gerenciais.

Não existem respostas certas ou erradas, o importante é você saber qual a sua percepção sobre cada informação apresentada.

O tempo estimado para concluir o questionário é de 20 (Vinte) minutos.

Todas as suas respostas serão tratadas de modo estritamente confidencial, serão registradas em um base de dados e analisadas em termos globais.

As questões sinalizadas com * são obrigatórias. Sua participação é voluntária, ao responder o questionário, você manifesta concordância com o presente termo de consentimento livre e esclarecido.

Desde já agradecemos a sua participação! 


\section{QUESTIONÁRIO - ETAPA 01 (PERFIL)}

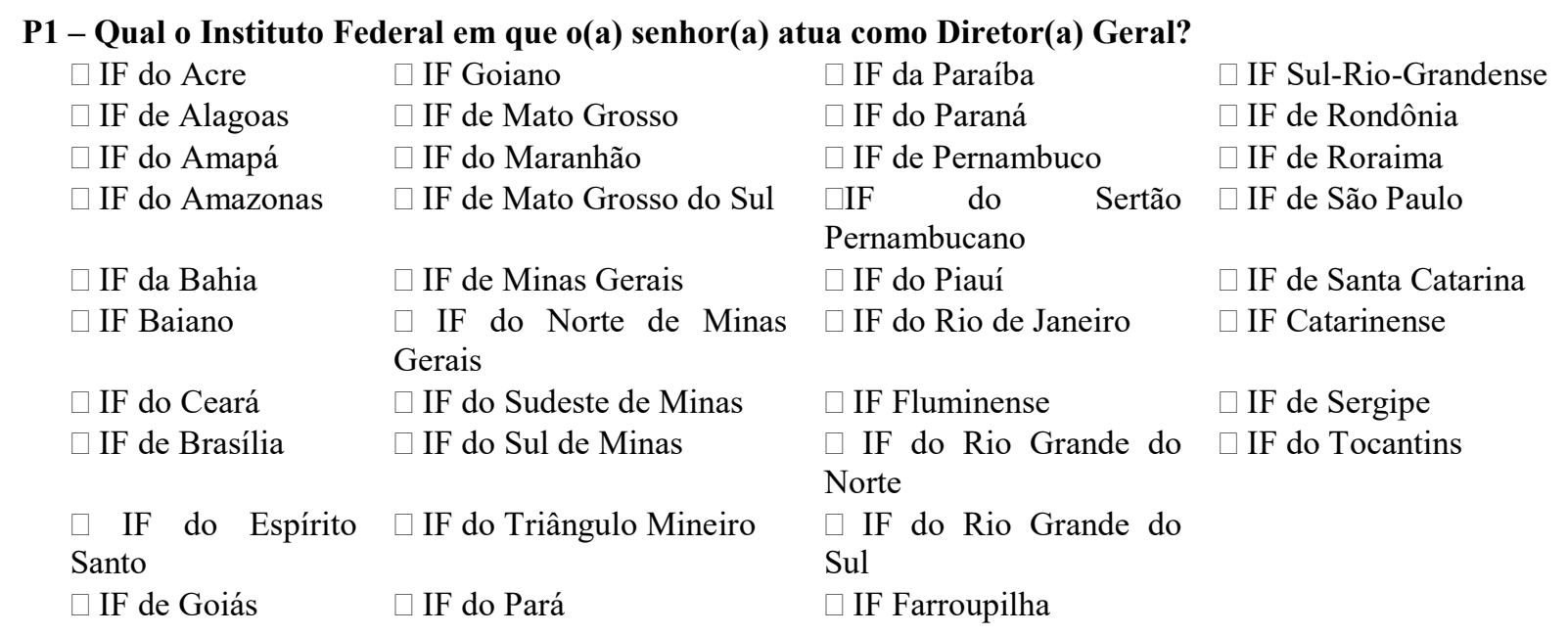

P2 - Há quanto tempo o(a) senhor(a) atua como Diretor(a) Geral?

$\square$ Até 1 ano e 11

meses

Enre 4 e 5 anos

$\square$ Entre 6 e 7 anos

Há 8 anos

\section{P3 - Qual o cargo no qual o(a) senhor(a) é servidor(a) efetivo(a)?}

$\square$ Professor do Ensino Básico, Técnico e Tecnológico $\square$ Técnico Administrativo em Educação

\section{P4 - Há quanto tempo o(a) senhor(a) atua como servidor(a) efetivo(a)?}

$\square$ Até 3 anos $\quad \square$ Entre 4 e 7 anos $\quad \square$ Enre 8 e 11 anos $\quad \square$ Entre 12 e 15 anos $\quad \square$ Há mais de 16

P5 - Sexo:

$\square$ Feminino $\quad \square$ Masculino

\section{P6 - Faixa etária:}

$\begin{array}{llllll}\square \text { Até } 20 & \square \text { Entre } 21 \text { e } 30 & \square \text { Enre } 31 \text { e } 40 & \square \text { Entre } 41 \text { e } 50 & \square \text { Entre } 51 \text { e } 60 & \square 61 \text { anos ou } \\ \text { anos } & \text { anos } & \text { anos } & \text { anos } & \text { anos }\end{array}$

\section{P7 - Estado Civil:}

$\square$ Casado(a) ou união consensual

P8 - Assinale a alternativa que corresponde ao seu maior nível de escolaridade:
$\square$ Ensino superio
Especialização.
$\square$ Mestrado
$\square$ Doutorado
Pós-Doutorado 


\section{QUESTIONÁRIO - ETAPA 02 (MATRIZ DE AVALIAC̄̃̃O DE COMPETÊNCIAS)}

$\Rightarrow$ P09 - Atualmente, no exercício da função de Diretor(a) Geral, qual seu nível de domínio de cada competência descrita abaixo?

\begin{tabular}{|c|c|c|c|c|c|}
\hline $\begin{array}{c}\text { Competências específicas da matriz de avaliação de } \\
\text { competências }\end{array}$ & 昜㤩 & 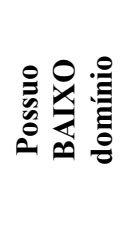 & 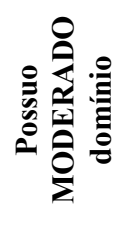 & 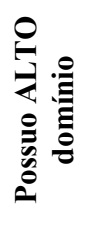 & 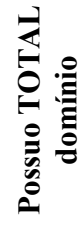 \\
\hline $\begin{array}{l}\text { Entender a si mesmo (autogerenciamento e conscientização) e os } \\
\text { outros (através da empatia) no ambiente organizacional }\end{array}$ & $\square$ & $\square$ & $\square$ & $\square$ & $\square$ \\
\hline $\begin{array}{l}\text { Comunicar (trocar informações, fatos, ideias e significados) com } \\
\text { honestidade e efetividade no ambiente de trabalho }\end{array}$ & $\square$ & $\square$ & $\square$ & $\square$ & $\square$ \\
\hline Orientar e desenvolver os funcionários da organização & $\square$ & $\square$ & $\square$ & $\square$ & $\square$ \\
\hline Gerenciar grupos de trabalho e liderar equipes na organização & $\square$ & $\square$ & $\square$ & $\square$ & $\square$ \\
\hline $\begin{array}{l}\text { Gerenciar e estimular o conflito construtivo e produtivo no } \\
\text { ambiente de trabalho }\end{array}$ & $\square$ & $\square$ & $\square$ & $\square$ & $\square$ \\
\hline $\begin{array}{l}\text { Organizar os fluxos (recebimento, processamento e saída) de } \\
\text { informação na organização }\end{array}$ & $\square$ & $\square$ & $\square$ & $\square$ & $\square$ \\
\hline Trabalhar e gerenciar em equipes multifuncionais & $\square$ & $\square$ & $\square$ & $\square$ & $\square$ \\
\hline Planejar e coordenar projetos & $\square$ & $\square$ & $\square$ & $\square$ & $\square$ \\
\hline $\begin{array}{l}\text { Medir e monitorar o desempenho e a qualidade dos processos e } \\
\text { resultados organizacionais }\end{array}$ & $\square$ & $\square$ & $\square$ & $\square$ & $\square$ \\
\hline $\begin{array}{l}\text { Estimular e possibilitar que os funcionários e a própria } \\
\text { organização busquem a conformidade (cumpram as regras) }\end{array}$ & $\square$ & $\square$ & $\square$ & $\square$ & $\square$ \\
\hline $\begin{array}{l}\text { Desenvolver e comunicar uma visão (um foco claro) } \\
\text { organizacional para os funcionários }\end{array}$ & $\square$ & $\square$ & $\square$ & $\square$ & $\square$ \\
\hline Estabelecer metas, objetivos, planos e estratégias organizacionais & $\square$ & $\square$ & $\square$ & $\square$ & $\square$ \\
\hline Motivar a si mesmo e as outras pessoas no ambiente de trabalho & $\square$ & $\square$ & $\square$ & $\square$ & $\square$ \\
\hline Projetar a estrutura e organizar o trabalho na organização & $\square$ & $\square$ & $\square$ & $\square$ & $\square$ \\
\hline $\begin{array}{l}\text { Gerenciar a execução das estratégias e buscar o alcance efetivo } \\
\text { dos resultados desejados da organização }\end{array}$ & $\square$ & $\square$ & $\square$ & $\square$ & $\square$ \\
\hline Usar o poder com ética e efetividade no ambiente de trabalho & $\square$ & $\square$ & $\square$ & $\square$ & $\square$ \\
\hline $\begin{array}{l}\text { Comunicar (apresentar, defender e vender) novas ideias no } \\
\text { ambiente de trabalho }\end{array}$ & $\square$ & $\square$ & $\square$ & $\square$ & $\square$ \\
\hline Estimular e promover inovação no ambiente organizacional & $\square$ & $\square$ & $\square$ & $\square$ & $\square$ \\
\hline Negociar acordos e compromissos com as pessoas na organização & $\square$ & $\square$ & $\square$ & $\square$ & $\square$ \\
\hline Implantar e sustentar a mudança na organização & $\square$ & $\square$ & $\square$ & $\square$ & $\square$ \\
\hline
\end{tabular}


$\Rightarrow$ P11 - No exercício de sua função de Diretor(a) Geral, qual o nível de frequência de uso de cada competência descrita abaixo?

Competências específicas da matriz de avaliação de competências

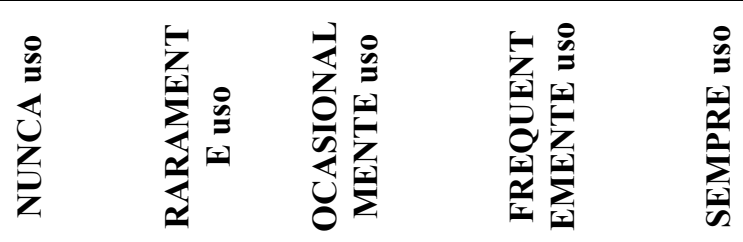

\begin{tabular}{|c|c|c|c|c|c|}
\hline $\begin{array}{l}\text { Entender a si mesmo (autogerenciamento e } \\
\text { conscientização) e os outros (através da } \\
\text { empatia) no ambiente organizacional }\end{array}$ & $\square$ & $\square$ & $\square$ & $\square$ & $\square$ \\
\hline $\begin{array}{l}\text { Comunicar (trocar informações, fatos, ideias e } \\
\text { significados) com honestidade e efetividade no } \\
\text { ambiente de trabalho }\end{array}$ & $\square$ & $\square$ & $\square$ & $\square$ & $\square$ \\
\hline $\begin{array}{l}\text { Orientar e desenvolver os funcionários da } \\
\text { organização }\end{array}$ & $\square$ & $\square$ & $\square$ & $\square$ & $\square$ \\
\hline $\begin{array}{l}\text { Gerenciar grupos de trabalho e liderar } \\
\text { equipes na organização }\end{array}$ & $\square$ & $\square$ & $\square$ & $\square$ & $\square$ \\
\hline $\begin{array}{l}\text { Gerenciar e estimular o conflito construtivo e } \\
\text { produtivo no ambiente de trabalho }\end{array}$ & $\square$ & $\square$ & $\square$ & $\square$ & $\square$ \\
\hline $\begin{array}{l}\text { Organizar os fluxos (recebimento, } \\
\text { processamento e saída) de informação na } \\
\text { organização }\end{array}$ & $\square$ & $\square$ & $\square$ & $\square$ & $\square$ \\
\hline $\begin{array}{l}\text { Trabalhar e gerenciar em equipes } \\
\text { multifuncionais }\end{array}$ & $\square$ & $\square$ & $\square$ & $\square$ & $\square$ \\
\hline
\end{tabular}

\section{Planejar e coordenar projetos}

\begin{tabular}{|c|c|c|c|c|c|}
\hline $\begin{array}{l}\text { Medir e monitorar o desempenho e a } \\
\text { qualidade dos processos e resultados } \\
\text { organizacionais }\end{array}$ & $\square$ & $\square$ & $\square$ & $\square$ & $\square$ \\
\hline $\begin{array}{l}\text { Estimular e possibilitar que os funcionários e a } \\
\text { própria organização busquem a conformidade } \\
\text { (cumpram as regras) }\end{array}$ & $\square$ & $\square$ & $\square$ & $\square$ & $\square$ \\
\hline $\begin{array}{l}\text { Desenvolver e comunicar uma visão (um foco } \\
\text { claro) organizacional para os funcionários }\end{array}$ & $\square$ & $\square$ & $\square$ & $\square$ & $\square$ \\
\hline $\begin{array}{l}\text { Estabelecer metas, objetivos, planos e } \\
\text { estratégias organizacionais }\end{array}$ & $\square$ & $\square$ & $\square$ & $\square$ & $\square$ \\
\hline $\begin{array}{l}\text { Motivar a si mesmo e as outras pessoas no } \\
\text { ambiente de trabalho }\end{array}$ & $\square$ & $\square$ & $\square$ & $\square$ & $\square$ \\
\hline $\begin{array}{l}\text { Projetar a estrutura e organizar o trabalho na } \\
\text { organização }\end{array}$ & $\square$ & $\square$ & $\square$ & $\square$ & $\square$ \\
\hline $\begin{array}{l}\text { Gerenciar a execução das estratégias e buscar } \\
\text { o alcance efetivo dos resultados desejados da } \\
\text { organização }\end{array}$ & $\square$ & $\square$ & $\square$ & $\square$ & $\square$ \\
\hline $\begin{array}{l}\text { Usar o poder com ética e efetividade no } \\
\text { ambiente de trabalho }\end{array}$ & $\square$ & $\square$ & $\square$ & $\square$ & $\square$ \\
\hline $\begin{array}{l}\text { Comunicar (apresentar, defender e vender) } \\
\text { novas ideias no ambiente de trabalho }\end{array}$ & $\square$ & $\square$ & $\square$ & $\square$ & $\square$ \\
\hline $\begin{array}{l}\text { Estimular e promover inovação no ambiente } \\
\text { organizacional }\end{array}$ & $\square$ & $\square$ & $\square$ & $\square$ & $\square$ \\
\hline $\begin{array}{l}\text { Negociar acordos e compromissos com as } \\
\text { pessoas na organização }\end{array}$ & $\square$ & $\square$ & $\square$ & $\square$ & $\square$ \\
\hline $\begin{array}{l}\text { Implantar e sustentar a mudança na } \\
\text { organização }\end{array}$ & $\square$ & $\square$ & $\square$ & $\square$ & $\square$ \\
\hline
\end{tabular}


Agradecemos a sua contribuição!

Quaisquer dúvidas ou esclarecimentos estamos a disposição.

Atenciosamente,

Francis de Sousa Fernandes

Mestrando em Administração e Controladoria

Universidade Federal do Ceará

francisdesousafernandes@,hotmail.com 